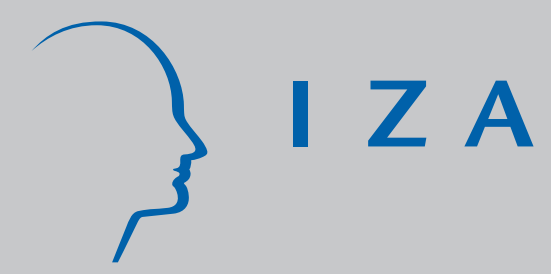

IZA DP No. 7635

Costs and Benefits of Labour Mobility between the EU and the Eastern Partnership Countries Country Study: Italy

Sabrina Marchetti

Daniela Piazzalunga

Alessandra Venturini

September 2013 


\title{
Costs and Benefits of Labour Mobility between the EU and the Eastern Partnership Countries Country Study: Italy
}

\author{
Sabrina Marchetti \\ RSCAS-EUI \\ Daniela Piazzalunga \\ University of Turin
}

Alessandra Venturini

$M P C$, University of Turin

and IZA

Discussion Paper No. 7635

September 2013

IZA
P.O. Box 7240
53072 Bonn
Germany

Phone: +49-228-3894-0

Fax: +49-228-3894-180

E-mail: iza@iza.org

\begin{abstract}
Any opinions expressed here are those of the author(s) and not those of IZA. Research published in this series may include views on policy, but the institute itself takes no institutional policy positions. The IZA research network is committed to the IZA Guiding Principles of Research Integrity.

The Institute for the Study of Labor (IZA) in Bonn is a local and virtual international research center and a place of communication between science, politics and business. IZA is an independent nonprofit organization supported by Deutsche Post Foundation. The center is associated with the University of Bonn and offers a stimulating research environment through its international network, workshops and conferences, data service, project support, research visits and doctoral program. IZA engages in (i) original and internationally competitive research in all fields of labor economics, (ii) development of policy concepts, and (iii) dissemination of research results and concepts to the interested public.
\end{abstract}

IZA Discussion Papers often represent preliminary work and are circulated to encourage discussion. Citation of such a paper should account for its provisional character. A revised version may be available directly from the author. 


\section{ABSTRACT}

\section{Costs and Benefits of Labour Mobility between the EU and the Eastern Partnership Countries Country Study: Italy ${ }^{1}$}

Migrants from the Eastern Partnership Countries: Moldova, Ukraine, Belarus, Georgia, Armenia, Azerbaijan has increased in the last ten years. Two different patterns are detected among the most important groups: Ukrainian and Moldovan. The first is mainly composed by women with a temporary migration plan while the second was initially composed by women but rapidly the family reunification was obtained and the migration plan became more permanent. By using the Italian Labour Force survey we analyse the employment situation, the over education of the migrants and their assimilation.

JEL Classification: J15, J26, J61, J62

Keywords: $\quad$ migration, labour market

Corresponding author:

Alessandra Venturini

University of Turin

Department of Economics

Via Po, 53

10124 Torino

Italy

E-mail: alessandra.venturini@unito.it

\footnotetext{
${ }^{1}$ This study was conducted under the project entitled "Costs and Benefits of Labour Mobility between the EU and the Eastern Partnership Countries" for the European Commission (Contract No. 2011/270312, tender procedure EuropeAid/130215/C/SER/Multi). The European Commission retains ownership of the materials contained herein.

We wish to thank Prof. Blangiardo and all the ISMU staff for supporting our research and for providing the information required, Matteo Ricchiardi for providing us the last LFS, Salvatore Strozza for his helpful suggestion, and finally our CARIM-EAST colleagues for discussion and references. We gratefully acknowledge the contributions and comments on an earlier draft from Martin Kahanec, Lucia Kurekova, and Simona Milio.
} 


\section{Table of contents}

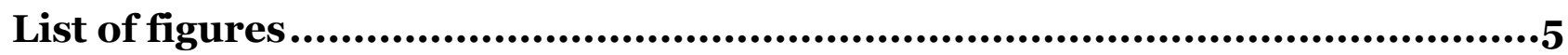

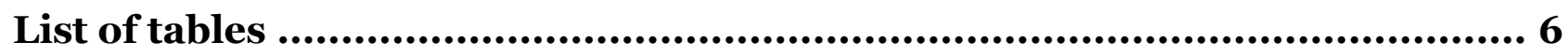

List of acronyms ..................................................................................7

Executive summary.................................................................................. 9

Introduction .......................................................................................... 14

Methodological remarks ........................................................................... 16

1. History of migration to Italy ................................................................. 17

1.1 Evolution of migration stocks and flows................................................................... 17

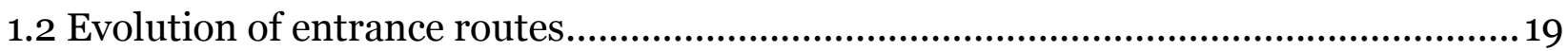

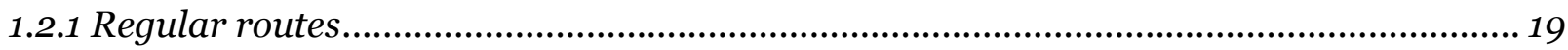

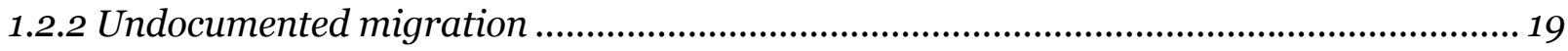

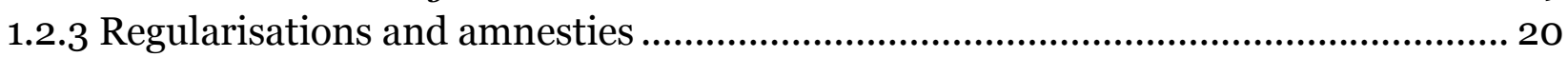

1.2.4 Agreements with third countries ..............................................................................2O

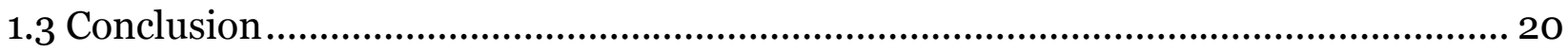

2. Characteristics of EaP migrants in Italy ...............................................22

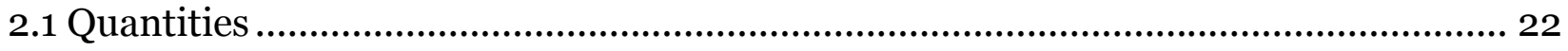

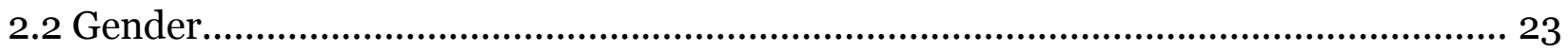

2.3 Age

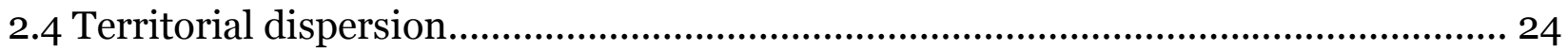

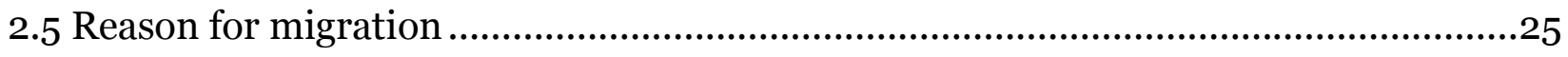

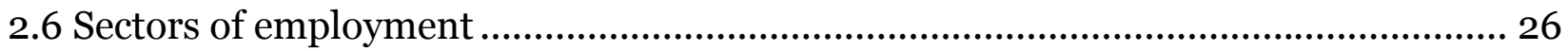

2.7 Temporary and permanent migration projects..............................................................27

2.7.1 The case of EaP migrants in Lombardy ………………..............................................2

2.7.2 EaP migrants in Campania ........................................................................................29

2.8 Irregular and undocumented migrants...................................................................... 30

2.8.1 Irregular migration to Italy ......................................................................................3

2.8.2 The main causes of illegal migration ………………....................................................32

2.8.3 Estimates and methodology ………………………..................................................... 33

2.8.4 Irregular migration from Ukraine and Moldova …………………………………….....33

2.8.5 The routes of irregular migration from EaP countries ....................................................34

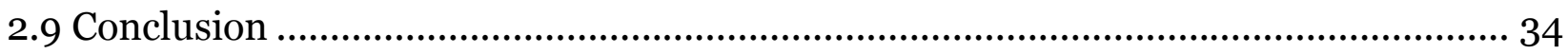

3. Employment and labour market..............................................................36

3.1. Employment and unemployment rate .................................................................... 36

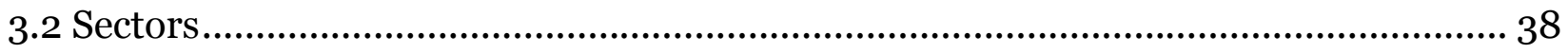

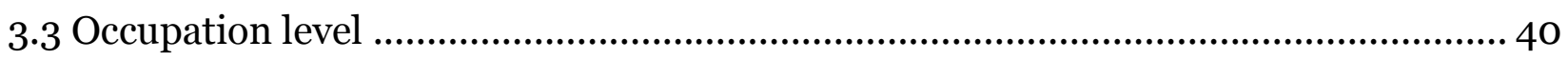

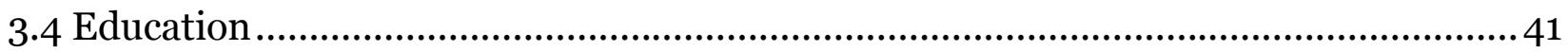

3.5 Education and skill mismatch ................................................................................... 42

3.6 Domestic and care labour sector ........................................................................... 44

3.6.1 Advantages and disadvantages ............................................................................... 45

3.6.2 The 2009 regularisation …………………………………………………………..... 45

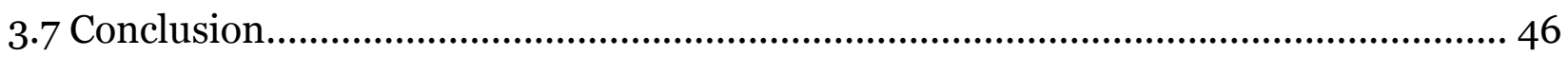




\section{Effects in destination and in sending countries}

4.1 Impact of immigration on the Italian labour market .......................................47

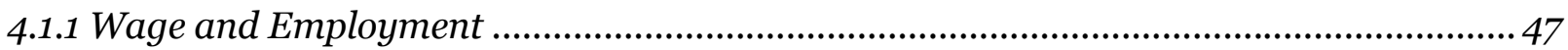

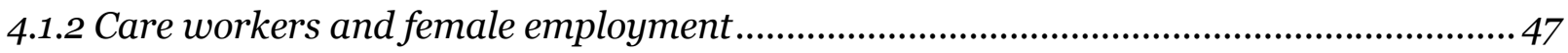

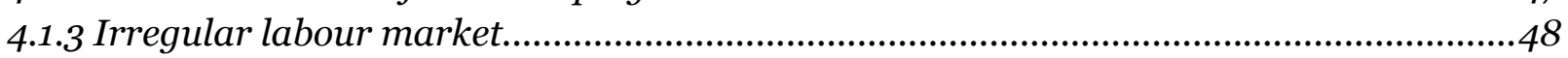

4.1.4 Competition between internal and international migrants...........................................48

4.2. Migrants and the down turn........................................................................ 48

4.3 Welfare, social services and migrant workers................................................ 50

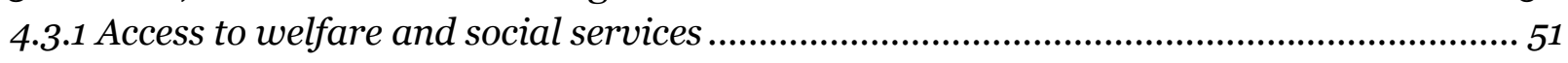

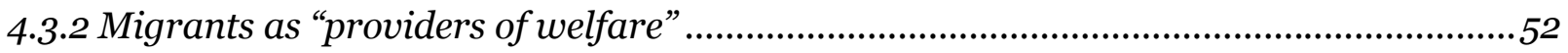

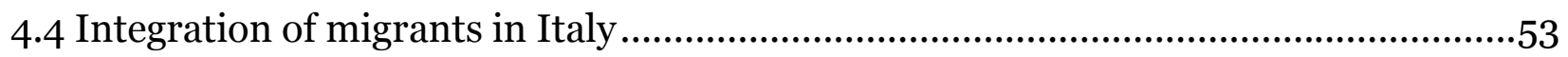

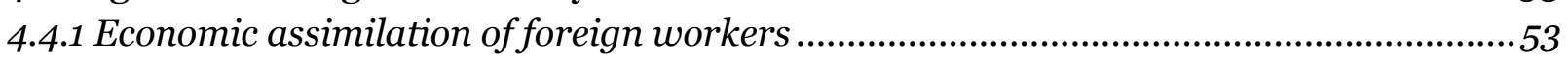

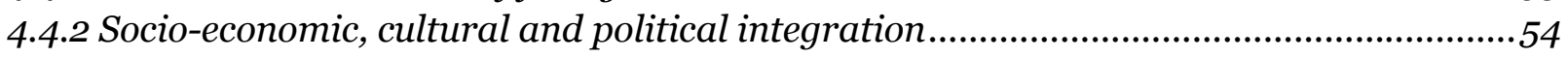

4.4.3 Integration policies ........................................................................................................ 55

4.4.4 Perceptions on immigration and ethnic-based discrimination in Italy ...........................56

4.5 Effects of migration in the sending countries ................................................ 58

4.5.1 Migration and the labour market ...............................................................................58

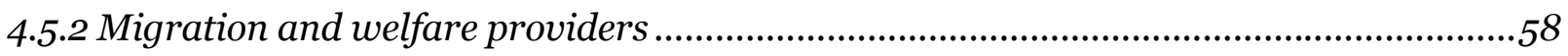

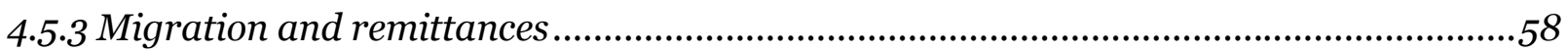

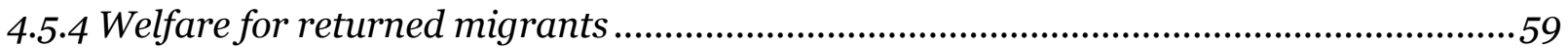

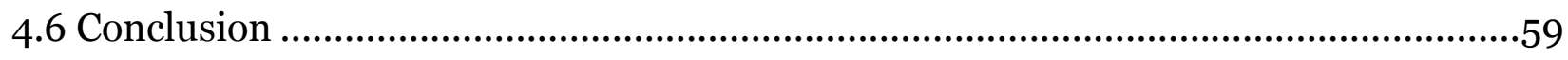

5. Is there demand for EaP migrants? .................................................6 61

5.1 CEDEFOP Skill labour demand in Europe ....................................................61

5.2 The forecast of employment in Italy ........................................................... 62

5.3 Forecasts from the Ministry of labour.......................................................... 63

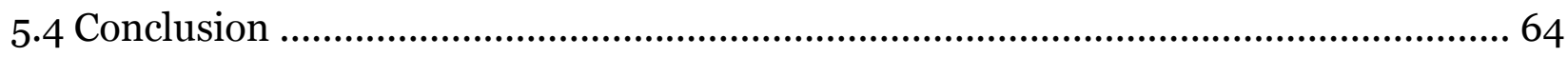

6. Legal framework on labour migration..................................................65

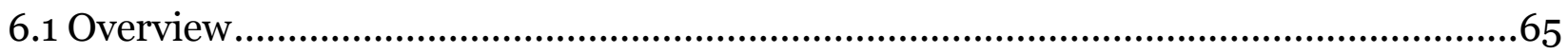

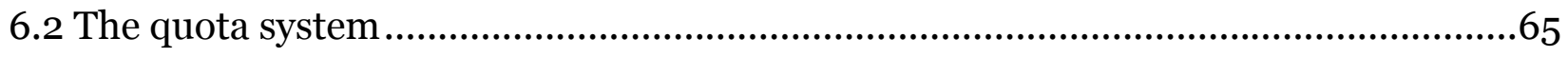

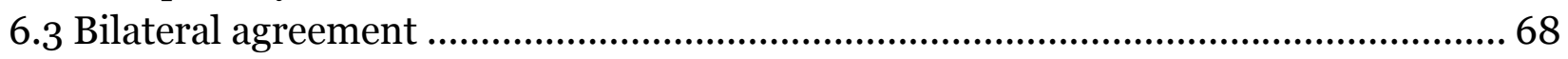

6.4 Control and repression of irregular migration................................................. 68

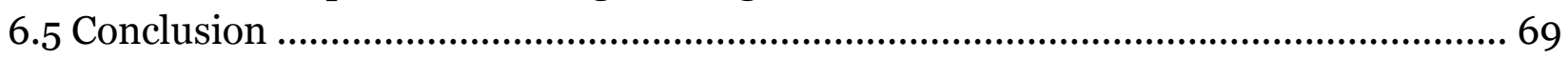

7. Policy measures ...............................................................................70

7.1 Current measures: control and integration .................................................. 70

7.1.1 Labour migration: critical issues ................................................................................ 70

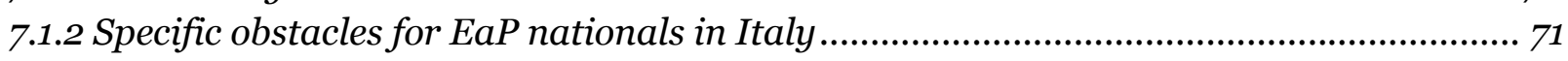

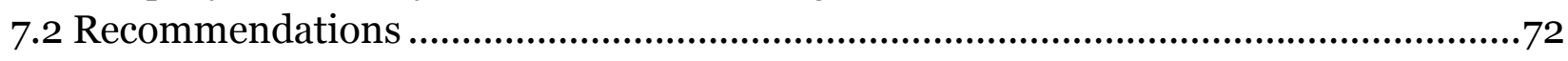

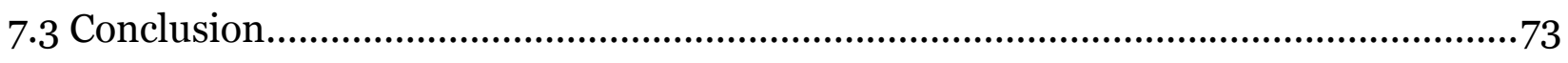

General conclusions ........................................................................74

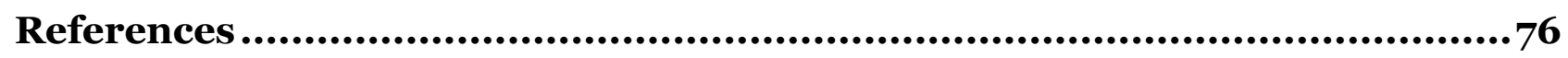

Annex I - Datasets .......................................................................... 84

Annex II - Tables ................................................................................ 86 


\section{List of figures}

Fig. 1.1 - Residence permits by main area of origin

Fig. 1.2 - Laws on migration and amnesties, compared to flows of workers family reunion members

Fig. 2.1 - Stock of residence permits for EaP countries, 1999-2011

Fig. 2.2 - Gender structure for EaP countries, compared with Russia and total immigrants, 2011

Fig. 2.3 - Age structure of immigrants from Moldova and Ukraine, compared with total immigrants and Italians, 2011

Fig. 2.4 - Rate of residence permits by reasons, 2010

Fig. 2.5 - Sectors of employment by gender, total immigrants and EaP countries, 2011

Fig. 2.6 - Estimated number of irregular migrants living in Italy. Years 1988-2010 (thousands)

Fig. 3.1 - Applications for permits as domestic and care workers

Fig. 4.1 - Employment rate by origin, 2008-2010 (1st quarter 2008=100, quarterly data) Fig. 4.2 - Unemployment rate by origin, 2008-2010 (1st quarter 2008=100, quarter data)

Fig. 4.3 - Foreign-native differentials in wages and days worked by ethnic groups with increasing experience in the labour market

Fig. 4.4 - Foreign-native differentials in wages and days worked by sectors with increasing experience in the labour market

Fig. 5.1 - Net employment change by broad occupational groups, 2010-20, Eu-27+ Fig. 5.2 - Vacancies rate in manufacturing and construction, 2004-2010(a) (quarterly data, percentage)

Fig. 5.3 - Residents (thousands) and demographic forecast in fours scenarios. 20002020

Fig. 6.1 - Planned flows 1996-2012 


\section{List of tables}

Tab. 2.1 - Foreign people from EaP countries as percentage of total immigrants and of Italian population, residence permits and foreign resident population, 2011

Tab. 2.2 - Regional distribution of immigrants from EaP countries, 2008

Tab. 2.3 - Intention to move of immigrants in Lombardy, by country of origin, 2010

Tab. 2.4 - Intention to family reunion of immigrants in Lombardy, by country of origin, 2010

Tab. 2.5 - Irregular migration to Italy, 2005-2011

Tab. 2.6 - Foreign population originating from main emigration countries irregularly resident in Italy. Major nationalities. Absolute and per cent values

Tab. 2.7 - Applications from EaP nationals during the last Italian amnesties

Tab. 2.8 - Ukrainians and Moldovans found to be undocumented and ordered to leave Tab. 2.9 - Types of Italian borders where entrance is refused

Tab. 3.1 - Employment status of foreign nationals and nationals, by gender, 2008, 2011. Share of working age population (15-64)

Tab. 3.2 - Employees versus self-employed (percentage data), by gender, 2011. Share of working age population (15-64)

Tab. 3.3 - Sectors of employment for EaP countries, with some major reference migration countries, by gender, 2011. Share of working age population (15-64)

Tab. 3.4 - Type of occupations (ISCO), by gender, 2011. Share of working age population (15-64)

Tab. 3.5 - Recognition of foreign qualification, EaP countries and total immigrants, 2008. Share of working age population (15-64)

Tab. 3.6 - Education level (ISCED 97) EaP countries and reference countries, by gender, 2011. Share of working age population (15-64)

Tab. 3.7 - Skill mismatch by gender (percentage), Moldova and Ukraine, and total immigrants, 2011. Share of working age population (15-64)

Tab. 3.8 - Average monthly wages (in $€$ ) for working age (15-64) immigrants from EaP countries and some reference groups, by gender, 2011

Tab. 4.1 - Unemployment rate 2008-2010 by nationality and area

Tab. 4.2 - Integration index by country of origin and fields, 2009

Tab. 4.3 - Perceptions of immigration: comparison between Italy and other European countries (UK, France, Germany and Spain)

Tab. 4.4 - Perception of discrimination based on ethnic or immigration origin as being "very" or "fairly" widespread, EU-MIDIS. All Italy based survey respondents Tab. 4.5 - Area of origin of victims of discrimination. Comparison 2010-2011 Tab. 5.1 - Non-seasonal hiring of immigrants scheduled by firms in services sector, by subsector ( $\max$ hypothesis, percentage on total hiring), 2008 - 2010

Tab. 6.1 - Flow decrees 1996-2012: quotas and characteristics 


\section{List of acronyms}

CARIM-EAST - migration observatory on the Eastern Neighbourhood the Migration Policy Centre of the European University Institute

CATI - Computer-Assisted Telephone Interviewing

CEDEFOP - European Centre for the Development of Vocational Training

Censis - Centro Studi Investimenti Sociali (Italian Institute of Socio-Economic Research)

Cie - Italian centers for identification and expulsion (of migrants)

CIS - Commonwealth of Independent States

Cpt - Italian Centers for temporary permanence (of migrants)

EaP - Eastern Partnership

EMN - European Migration Network

ETF - European Training Foundation

EU - European Union

EU15 - The 15 member countries in the European Union prior to the accession of ten candidate countries on 1 May 2004 (Austria, Belgium, Denmark, Finland, France, Germany, Greece, Ireland, Italy, Luxembourg, Netherlands, Portugal, Spain, Sweden, United Kingdom).

EU25 -The 25 member countries in the European Union prior to the accession of Bulgaria and Romania on 1 January 2007 (EU15 + Cyprus, Czech Republic, Estonia, Hungary, Latvia, Lithuania, Malta, Poland, Slovakia, Slovenia)

EU-MIDIS - European Union minorities and discrimination survey

EU-SILC - European Union Statistics on Income and Living Conditions

Excelsior - Italian survey on labor market needs

FRA - The Fundamental Rights Agency of the European Union

GDP - Gross Domestic Product

IDOS - Research center of Caritas-Italy and Migrantes Foundation

IER - Institute for Employment Research

ILO - International Labour Organization

INEA - Istituto Nazionale di Economia Agraria (Italian national institute of agricultural economics research)

INPS - Istituto Nazionale della Previdenza Sociale (Italian national social security institute)

IOM - International Organization for Migration

ISCED - International Standard Classification of Education

ISCO - International Standard Classification of Occupations

ISMU - Iniziative e Studi sulla Multietnicità (Italian independent research centre on multiculturalism)

Istat - Istituto nazionale di statistica (Italian National Institute of Statistics) 
ITC - Information and Communication Technology

LFS - Labour Force Survey

MSF - Médecins Sans Frontières

MPC - Migration Policy Centre

OECD - Organisation for Economic Co-operation and Development

UNAR - Ufficio Nazionale Antidiscriminazioni Razziali (Italian National Office against Racial Discrimination)

VELA - Quarterly survey on job vacancies and hours worked conducted by Istat WHIP - Work Histories Italian Panel (developed by University of Turin, LABORatorio Riccardo Revelli, and INPS) 


\section{Executive summary}

\section{Composition}

Migrants from EaP countries are an increasingly relevant reality in Italian society. From the mid 1990s, people started to arrive from Ukraine and shortly after from Moldova, who were then followed by very limited numbers of migrants from the other EaP countries: Armenia, Azerbaijan, Belarus and Georgia.

Today, Moldovans and Ukrainians constitute a sizeable number of 142,000 and 218,000 , respectively. If we consider the residence permit data (excluding migrants from the European Union), immigrants from EaP countries account for 10 per cent of the foreign population in Italy, of which Ukrainians account for 6 per cent and Moldovans 4 per cent.

Women outnumber men among EaP migrants. The share of women reaches 80 per cent among Ukrainians and 90 per cent for Georgians.

Family reunification does not play a significant role for EaP migrants in Italy. For instance, only 25 per cent of Ukrainians and 35 per cent of Moldovans applies for a residence permit for family reasons - compared to 47 per cent for total immigrants (see Figure 2.4). It varies for men and women, with family reunification the lowest for Ukrainian women, at only 20 per cent.

EaP communities present two different models: Ukrainians are mainly female, older, aged 50-55 and with a temporary migration pattern; Moldovans have a more permanent and settled model of migration, the mode of their distribution is in the age bracket 30-34, and they are younger than the average foreign population.

The migration dynamic from Belarus, Georgia and Ukraine to Italy is very similar, as is the the gender structure. This suggests that immigrants from Belarus and Georgia have a similar migration pattern to Ukraine, and not to Moldova, where the male component is larger, and which is similar to Romanian migration. Migrants from Armenia and Azerbaijan are not a mass flow and they melt away in the labour force statistics because they are not concentrated but rather they are small frequently very highly-skilled elites.

Migrants from EaP countries are distributed all over Italy. Although, men from Moldova work mainly in Emilia Romagna, and Ukrainians have a tradition of arriving in (and often keeping strong ties with) Campania. Belarusians and Georgians arrive in the south, where it is easy to find informal work and after which they move to the centre and to the north, where higher quality job options are available. Azerbaijanis, though in small numbers, are concentrated in the north or in central Italy and Armenians in the north-east, where the old diaspora has settled.

Undocumented migration exceeds 10 per cent amongst non-EU Eastern countries. In particular, irregular immigrants from Ukraine are 13.9 per cent of resident immigrants, and 14.5 per cent from Moldova. In this ranking, Ukraine is the third country in absolute terms $(28,000$ irregular immigrants, 6.7 per cent of all irregular migrants) and Moldova the sixth (17,000, 4.1 per cent of all irregular migrants). 
Since migration from EaP countries is quite recent, migrants from this area who obtained Italian citizenship are few (69 people from all EaP countries).

\section{Employment and education}

Immigrants from EaP countries came to Italy for labour purposes, above all. It is not surprising then, that their activity rate of 78 per cent is higher than that for the all other foreign nationals (70 per cent), with the exception of the Philippines, and, of course, higher than that for Italians (6o per cent).

From 2008 to 2011, the activity rate of EaP migrants remained stable or increased, thanks to the rise in the employment of the female segment and thanks to a reduction in the unemployment of Ukrainians and Moldovans especially. This is in contrast with the activity rate and employment rate of Italians and, indeed, of all immigrants declined, as the unemployment rate increased.

The share of male EaP migrants employed in the industrial sector is in line with the Italian men participation (55 per cent), but the proportion of women in the social and family service is very high, at 70 per cent.

EaP male migrants are employed in the manufacturing and construction sectors: manufacturing, trade and construction, following the distribution of male Italians and other male migrants.

Female migrants from EaP are concentrated in social and personal services (71 per cent and 66 per cent), with a smaller presence in hotel and restaurants (9 per cent) and support services activities (6-10 per cent). In so doing, they show a very different tendency than native women who are mainly employed in education, health and social work, services and manufacturing.

Self-employment is not very diffused among EaP workers: it is 4 per cent, with the exception of Moldovan men for whom it reaches 10 per cent.

Care and domestic work is central to understand migration from EaP countries to Italy. In fact, they retain an increasingly important position compared to other immigrant groups: Moldovans, Ukrainians and Belarusians have doubled their participation in the sector.

The skill distribution of EaP migrants in Italy is strongly gender biased. Relative to the average of male migrant skill, Ukrainians and Moldovans are more present in skilled positions with respectively 51 per cent and 58 per cent as skilled manual workers. Female EaP migrants work instead in elementary occupation or as service and sale workers.

The education level of EaP migrants is higher than in other immigrant groups in Italy: the share of women with a tertiary level of education is 26 per cent from Ukraine ( 6 per cent of men), and 14 per cent from Moldova (17 per cent of men) and 21 per cent of women from Belarus. 
However, most of them do not ask for recognition of their foreign qualifications because these are not considered relevant for the job in which they are employed. A mere 6 per cent of Ukrainians asked for recognition, admittedly a higher percentage with respect to other immigrants.

The average wage for women and men is respectively 793 Euros and 1.053 for Ukrainians, and 754 Euros and 1,137 Euros for Moldovans. This shows a higher gender wage gaps in comparison with Italians: 34 per cent for Moldovans and 25 per cent for Ukrainians.

\section{Legal framework}

The Italian migration framework is characterised by the fact that labour is the main option for the entitlement of a stay permits. The Bossi-Fini Law of 2002 introduced the combination of the planned flows system and the on-call principle. Since then quotas are the only way in, and they are set annually by specific governmental decrees for seasonal and non-seasonal work.

From the late 1990s, Italy has also tried to favour legal inflows by signing agreements with migrants' countries of origin, such as readmission agreements and mobility partnerships. The first mobility partnership was signed with Moldova, in 2003.

From the point of view of Italian migration policies, care and domestic workers offer advantages in comparison to other employment sectors. Already in the 2002 regularisation domestic and care workers received special treatment with the extension of the deadline for applications. More recently, in 2009, an amnesty was given expressively to this sector. Moreover, the annual allocation of quotas for foreign workers always assigns a relatively high number of permits to prospective care and domestic workers.

Ukrainian and Moldovan workers can access a specific allocation of quotas on the basis of bilateral agreements in place between Italy and their countries.

\section{Costs and benefits of EaP migration to Italy}

Migrants in Italy are not competitive with the workers looking for jobs in the area where they work. Rather they complement them. Migrants displace workers from the less advantaged regions (in the south of Italy) who are ready to move internally.

This creates a double advantage for the workers in the more developed areas (in the North), where the migrants work, because they complement labour and capital, while it produces a double disadvantage for the less developed areas (in the South) where there are potential native migrants who would like, as they had done in the past, to move in search of jobs, but they are now taken by foreign nationals. The presence of available labour in the more developed regions also disincentives the move of capital in the less developed ones and this create the second disadvantage.

Likewise, female migrants employed in the family services are complementary towards native female workers. Foreign migrants working in the family sectors as 
care givers for children, old age people and help in the houses favour the labour force participation of highly skilled women who work in other sectors.

In Italy, EAP migrants use public welfare and social services less than natives. First of all, they use less contributory benefits (pension, unemployment) because they are younger. Morover, it is unlikely that women working as care givers have the possibility of using welfare a lot because they are in general older, not in reproductive age and they rarely have children with them.

The cost of migrants on the Italian social security system is minimal in comparison to the "resources" they actually bring, through their employment in the home-care sector. In fact, the employment of migrant care workers is a "resource" for Italian welfare, providing an assistance that is continuous and personalised with relatively small costs for Italian families. The Ministry of Labour estimated that the Italian state is saving six billion annually, thanks to the work of these women.

The forecasts show an increasing demand of foreign labour in the Italian economy. This depends on the aging of population which engenders a specific demand in terms of services for old aged persons, and the reduction of the domestic labour supply. The recession reduces the total demand of labour and probably spurs an upgrading in production technology or a downgrading in the informal sector. The demand of foreign labour are 9 per cent highly skilled, 31.6 per cent medium skilled and 60 per cent low skilled. The 15 positions most in demand for non seasonal foreign workers are cleaners first, construction workers in stone second, waiters and similar as third. Three main sectors dominate demand: the services to aged persons, restaurants/bars and construction.

\section{Integration}

Migrants never assimilate to native levels either in terms of wages or employment. The wage differentials between natives and foreign nationals of similar characteristics exist at the threshold of employment and that these increase as long as migrants reside and work in the destination country.

An overall integration index by ISMU illustrate the characteristics of migrants' integration following four main dimensions: economic, political, social and cultural. Moldovans and Ukrainians have average scores of cultural integration as a result of the higher level of education among EaP migrants. They have instead low levels of economic, social and political integration because the private service sector in which they are mainly employed at does not provide any career progression, does not reward their skills, and reduces possible interactions outside the family where the migrant is employed. The low political integration is a consequence of a low interest in acquired Italian citizenship and of the widespread irregular status.

\section{Policy measures}

Against this background, the position of EaP migrants within the Italian labour market and in society at large is hindered by the following features which 
characterise their current presence in Italy marked by their employment in the care and domestic sector:

- The disproportionate presence of women with a temporary migratory project, working in a very isolated environment and with scarce motivation and opportunities for socio-economic mobility and cultural or political participation in the Italian context.

- Their channelling into specific labour sectors predominantly perceived as "jobs for foreigners". These are jobs, like domestic work, characterised by a lack of social network and opportunities for career and training. This places them in a troubling position within the Italian economy and society, hampering, once again, their social mobility.

- Their involvement in irregular employment and the informal economy which might go against rights acquisition, at the social and political level, i.e. access to citizenship and to social security.

Possible changes in the framework on labour migration law would improve the conditions of EaP migrants in Italy. For example:

- changing the selection and hiring procedures, by introducing the "sponsor system" and by allowing entrance into the country for job seeking. Similarly, a reconfiguration of the quota-system will be needed in order to better adjust the determination of quotas to the actual needs of the Italian economy.

- supporting temporary and circular forms of migration. This would mean strengthening the policies on return migration, especially bilateral arrangements on pension portability which is very relevant to EaP migrant domestic and care workers.

- sustaining the process of integration into the Italian labour market. This should be done by enhancing their opportunities to train and for career mobility. An emphasis on their labour opportunities would, in turn, increase their chances of political and social integration.

- from an EU perspective, promotion of bilateral agreements between Italy and other EaP countries - as the one already in place with Moldova. Likewise, the EU should also foster the implementation of integration measure, in line with the Global Approach on Migration and Mobility.

In conclusion, a new approach on labour migration would bring improvements for the labour conditions and the social integration of migrants from EaP countries. The irregularity which affects their arrival and settlement in the country would be effectively reduced. At the same time their contribution to Italian society and economy would be more visible and therefore, one would assume, better acknowledged. 


\section{Introduction}

The aim of this country report is to provide a clear picture of migration from the Eastern Partnership (EaP) countries in Italy, with an accurate description of the characteristics of these migrants, their role in the labour market and in the Italian economy.

In so doing, the study relies on qualitative and quantitative surveys conducted by national and international research institutes and special data gathering for the communities of interests made available on request for the project. An extended methodological section and careful description of the source is available at the end of report and in the Annex I.

The aim has been to derive from different sources the predominant trends of EaP migrants to Italy. However, if data on Moldovans and Ukrainians in Italy are abundant, information on migrants from the other EaP countries is very scarce. The report tries to overcome this limitation by using the limited information available and extend the patterns followed by Moldovans an Ukrainians to the other EaP groups.

The report describes labour migration from EaP countries looking at its costs, its benefits and the future development of its demand. The report also discusses the possible effects that different migration patterns can have in the sending countries, while offering an aggregate picture and suggesting policies that might spur positive aggregate results.

It is organized as follows.

Chapter 1 addresses the history of migration to Italy, summarizing the economic and historical changes that made Italy to become an immigration country, from its past of emigration. Particular emphasis is give to the increasing visibility of Eastern European migrants. This chapter also sums up the different policies that affect immigration towards our country.

Chapter 2 offers an overview of the social and demographic features of migrants from the Eastern Partnership countries in Italy. The differences in their most significant migratory patterns are here discussed. The chapter concludes with a focus on irregular migration from this area.

In Chapter 3, the main labour market outcomes for migrants from EaP countries are described. Here the focus is on the bigger EaP groups that have arrived to Italy, Moldovans and Ukrainians, that are compared with other main immigrant nationalities in the country. Since most Moldovans and Ukrainians are women employed as domestic and care workers, the chapter also discusses some peculiar characteristics of this sector, his pro and cons.

Chapter 4 provides an analysis of the effects of migration on the Italian and the sending societies, at the same time. In the first part of the chapter, we discuss the impact of migrants from EaP countries on the labour market, their position in the field of welfare and social services, their integration at different level (economic, social and political). In the second part, the trends of the labour market and the welfare demand in the sending countries are examined. 
By focusing on labour, which is the predominant reason for migration amongst EaP nationals, Chapter 5 discusses the demand for migrants in Italy on the basis of surveys on skills and employment (CEDEFOP and Ministry of Labour).

Chapter 6 provides an overview of the legal framework for entrance and labour of foreigners in Italy. The quota system is illustrated in details, highlighting the position of EaP nationals within this entrance scheme.

Finally, chapter 7 addresses Italian and European current migration policies, with their limitation and their impact on migrants from EaP countries. This discussion is further developed into some policy recommendations. 


\section{Methodological remarks}

A large number of statistical sources, qualitative surveys and policy papers are available today on the topic of migration to Italy. Amongst the publications that, in different ways, elaborate on this issue, this study mainly uses data provided by Istat, the National Institute of Statistic, and other Italian public institutions such as CNEL, INPS, INEA and UNAR. These are combined with facts elaborated by independent and private Italian research centres that have a particular focus on migration, such as CENSIS, ISMU and IDOS. A comprehensive table on available sources on migration, with their pros and cons, is provided in Annex I.

Unfortunately, in the search of information on migrants from EaP countries in Italy, our study has been affected by a disproportionately large amount of data on Moldovans and Ukrainians, and a small amount available for people from Armenia, Azerbaijan, Belarus and Georgia. In fact, while migrants from the first group are, especially after the big regularisation of 2002, a major object of attention in research and social policy, the latter group is scarcely studied due to the limited amounts of these nationals in Italy.

Chapter two, on the general features of this migration flow, is based on data elaborated by Istat on resident foreign population and on residence permits on the basis of statistics from the Home Office. Chapter four, instead, on employment and labour market outcomes, elaborates on the last batch of data from the Istat Labour Force Survey available at the time of writing this report, which was the LFS $2011-2^{\text {nd }}$ quarter. We also eventually use the LFS $2008-2^{\text {nd }}$ quarter batch since this contains an ad hoc module for foreign people which it is interesting to discuss in some instances.

Another important source of material for this research is the ISMU Foundation. ISMU provides estimates on irregular migration and the Integrometro survey which is very relevant in order to assess the integration of migrants in Italy. We also use ISMU data in order to discuss the case of migrants in Lombardy and Campania, in relation to their migratory projects. Equally important in our study are the numbers provided by the IDOS research centre of CARITAS/Migrantes that annually publishes facts on migration, integration and related social issues. IDOS is also the Italian local research office of the European Migration Network.

The report makes moreover extensive use of facts and figures from European and international organizations, both of public and private character, such as the CEDEFOP, the EU Fundamental Rights Agency, the European Migration Network, the International Labour Organisation, the European Migration Network, the European Training Foundation and well as Médicines Sans Frontièrs and the World Bank.

Finally, in relation to the use of secondary literature, we make reference to working papers, journal articles and essays from national and international academic and policy debates. Examples are the working-papers produced by the CARIM-East project which is conducted by the Migration Policy Institute at the European University Institute and which studies migration from and within the Eastern Neighbourhood of the European Union. 


\section{History of migration to Italy}

\subsection{Evolution of migration stocks and flows}

Italy is generally perceived as a very recent immigration country. Indeed, it is true that not until the beginning of 1990 s did the consistent presence of migrants in the country begin (in 1992 migrants accounted for 1.15 per cent of the population). In the 1990s, migration became a topic for media, policy makers and social actors, with a flourishing interest in terms of research and cultural production. Yet, migrants had come to Italy earlier, during times in which Italy still saw itself as an emigration country. ${ }^{2}$

The first arrivals date back to the beginning of the twentieth century, with Chinese settling in northern Italy. This is also true for individuals from the former Italian colonies of Eritrea, Ethiopia and Somalia who came to Italy as students, for business or later on as labour migrants. Other very early arrivals included Tunisians working as fishermen in the area of Mazara del Vallo, in Sicily, and men from the former Yugoslavia employed as construction workers in the north-east. Towards the end of the 1960s, and more consistently during the 1970s, there was a flow of foreign women - especially from Cape Verde, Eritrea and the Philippines -as domestic workers in the big Italian cities.

At the end of the 1970s, when the oil-driven recession hit Northern Europe, the countries affected adopted restrictive immigration policies. At this point, Italy became the secondchoice destination for all the potential migrants from neighbouring areas (North Africa) and Asia (mainly Philippines) and Latin America.

Figure 1.1 on the legal resident in Italy shows the evolution of the stock of foreign nationals. The dotted lines represent the years in which the legalisations were implemented and the steps in the inflow profiles show the results of the illegal entrances transformed by the amnesties into legal residents. Neighbouring Southern European countries adopted the same model: Greece, Portugal and Spain also have a long history of emigration and have had difficulties in controlling their borders. Figure 1.1 also shows the changes in the composition of the inflows (in the same way that Table A.1 in the Annex shows the change in the top-20 immigration countries to Italy).

After 1989, with the fall of the Berlin Wall, inflows began from the Eastern European countries. Initially, the migrants came from neighbouring Albania, but they later arrived from more distant Romania, attracted by the similarity between the Italian and Romanian language. In time, they came from countries further away: Moldova and Ukraine. Some Ukrainians were already in Naples at this time due to that city's connection with the port of Odessa.

In 1990, Eastern Europeans were still a small group. But the regularisation of 2002 reflected the increase of Eastern Europeans in Italy, whose presence almost doubled (a rise of 89 per cent). Among the ten nationalities which most profited from the regularisation, five of them belonged to the East: Romanians (20.4 per cent), Ukrainians (15.2 per cent),

${ }^{2}$ The migratory balance inverted in 1972 , when the number of migrants to Italy outnumbered Italian emigrants, for the first time (Venturini, 2001, p. 5). See also Venturini (2004, p. 10) and Del Boca and Venturini (2005, pp. 303-336). 
Albanians (7.9 per cent), Poles and Moldovans in smaller proportions. Combined these covered 52 per cent of the applications submitted. After regularisation, the number of Ukrainians in Italy increased eight fold, Moldovans five times and Belarusians by 57.7 per cent3 Eastern European women are particularly prominent: they regularised their status on the basis of labour contracts as domestic or care workers. They numbered 89,029 from Ukraine, 63,573 from Romania, 25,002 from Poland and 22,501 from Moldova. In other words, four out of five people from Moldova, Romania and Ukraine regularised their position in this sector.

Fig. 1.1 - Residence permits by main area of origin, 1971-2011

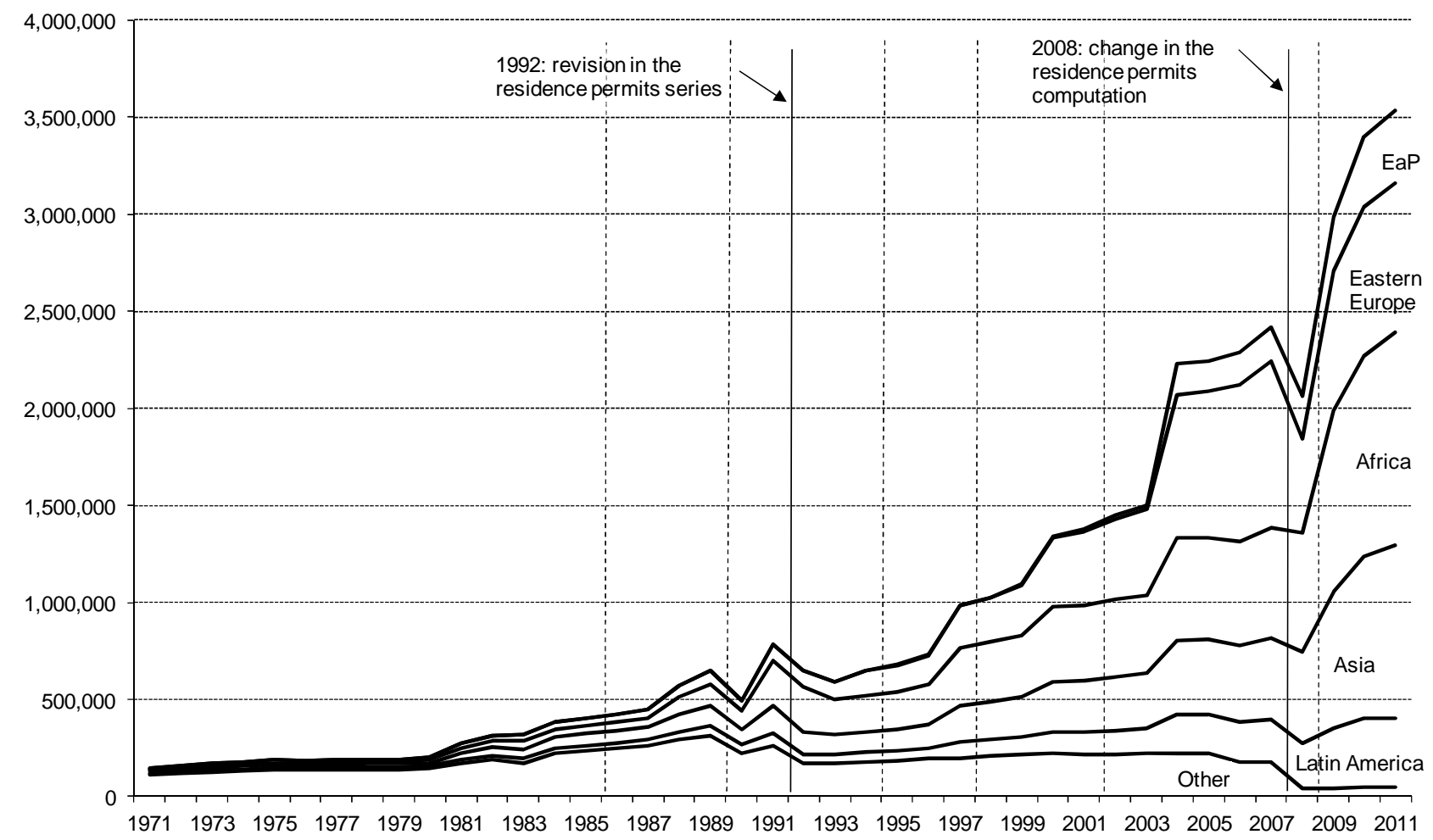

Source: Own elaborations based on Istat, Residence permits (data from the Home Office).

Notes: Dotted lines correspond to the amnesties (1986, 1990, 1995, 1998, 2002, 2009), while the continuous lines correspond to revisions in the residence-permit computation (see Annex).

The second EU enlargements of 2007 had profound repercussions on Italy, where the number of Romanians in particular increased dramatically. As European citizens they were exempt from residency permit regulation and freely mobile in EU member states (since Italy had no 'transition period' for the new EU-members). Figure 1.1 shows the decline in the total profile for the 2008, as a result of the change in the institutional setting.

In 20o9, the total number of migrants increased mainly through regularisation. However, this affected only people working in the care and domestic-service sector.

3See Bentivogli, Carfagna and Pittau (2004, p. 251). 


\subsection{Evolution of entrance routes}

In the 1970s and 1980s Italy was largely unprepared to regulate the migrant workers who were arriving in increasing numbers, and consequently relying on informal ways to enter and find employment. From the 1990s, reforms in Italian migration law intensified - often as an expression of the changes in the political coalitions at the governmental level. Yet, from the labour perspective, this sequence of different legal frameworks has not resolved the problems of foreign labour forces in the country.

\subsubsection{Regular routes}

The Italian migration framework is characterised by the fact that labour is the main option for "entitlement of a stay" permits. Both the Martelli Law (1990) and the Turco-Napolitano Law (1998) conferred a legal residence permit on all people with a work contract during the 1990s, while the 2000s saw an introduction of the combination of the planned flows system and the on-call principle. Since the Bossi-Fini Law (2002), on migration, quotas are the only way in, and they are set annually by specific governmental decrees for seasonal and non-seasonal work. When they apply, prospective workers have to formally reside in their country of origin. In more recent years, the number of people allowed a residence permit for the purpose of family reunion or study has definitively been growing - although labour remains the major channel of entrance, and this is also true for women.

\subsubsection{Undocumented migration}

The planned flows system and the on-call contracting principle revealed each year to be inadequate in regulating the entrance of migrants to Italy. First, the numbers established with the annual quotas have not met the requests from each labour sector. Second, the idea of hiring someone with whom you have not a personal contact proved unrealistic especially in the domestic and care sector. As we will see, amnesties and regularisation have thus been adopted as a way to legalise the entrance and hiring of the majority of workers after the fact. At the same time, the promulgation of the so-called Security Package in 2008,4 increased the penalty for people found without permission to stay.

The high proportion of irregularity among migrant workers is proven by two interesting data points. First is the number of people who, thanks to these amnesties and regularisations, "emerge" from their invisibility of their condition (see Figure 1.2). Second is the number of people apprehended because they are found without a permit. This number of course varies depending on the level and type of security checks, which changes over time. It is important to consider that, despite the common image of Italy as a country exposed to irregular migration because of its position in the Mediterranean Sea, it is the air borders rather than maritime borders where most irregular migrants are intercepted.

4 Law n. 92 of 23/05/2008 (later law n. 125 of 24/07/2008). 


\subsubsection{Regularisations and amnesties}

As has already been noted, Italy has often turned to special decrees to deal with the presence of irregular migrant workers in the country. Figure 1.2 shows that these measures have regularised a far higher number of people than was the case in planned flows.

Amnesties and regularisations have taken place ten times: 1981, 1986, 1990, 1995, 1998, 2002 and 2009. Figure 1.2 indicates, next to the date of each amnesty, the name of the ministers who promoted each of them. The amnesties of 1990, 1998 and 2002 corresponded to the promulgation of a new migration law, and the regularisation of the

Fig. 1.2 - Laws on migration and amnesties, compared to flow of workers family reunion members

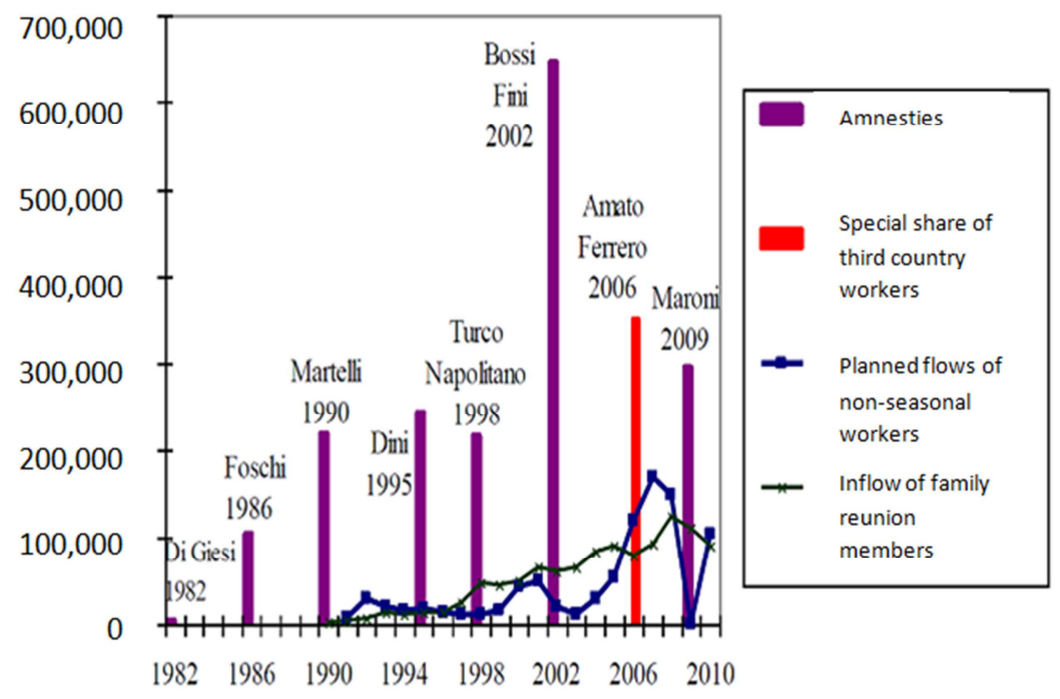

2009 was a very specific measure, directed to workers employed in the care and domestic sector.

The amnesty of 2002 - with its regularisation of more than 600,000 people, represents a turning point in the reconfiguration of migrants in Italy: from a predominantly male and Northern African composition to an Eastern European and female one.

Source: Einaudi (2011)

\subsubsection{Agreements with third countries}

From the late 1990s, Italy has also tried to favour legal inflows by signing agreements with migrants' countries of origin, such as readmission agreements and mobility partnerships. The first mobility partnership was signed with Moldova in 2003, and with Egypt and Morocco in 2005. The following have progressively had access to an exclusive portion of annually planned flows: Albania, Algeria, Bangladesh, Gambia, Ghana, India, Niger, Nigeria, Pakistan, the Philippines, Somalia, Sri Lanka and Ukraine.

\subsection{Conclusion}

In this first section of our report, we provide information on the evolution of the migratory phenomenon in Italy. A difficult path emerges, which Italy has undertaken in order to enact a transformation from a country of emigration into one of immigration.

The flow of migrants to Italy has gradually increased and its peak coincided with the collapse of the former Soviet Union, in the 1990s. Thus, Italy's role as one of the major countries of destination in Europe is associated with the increasing relevance of Eastern Europeans - and EaP nationals among them - as migrant actors (see Figure 1.1). 
The second part of this section briefly outlines the changes in Italian legislation on migration, which went hand in hand with the evolution of migratory settling in the country. The centrality of periodic regularisations and amnesties (see figure 1.2) of the quota system for labour migrants, and of the measures to control and prevent irregular entrances will be discussed in greater detail in Section 6. 


\section{Characteristics of EaP migrants in Italy}

As noted in Section 1, immigration to Italy began with illegal or irregular entry (tourist or student visas) which became regular through amnesties. Thus irregularity is part and parcel of the migration plan and it is not generally permanent.

The information presented below is derived from both official sources which portray the characteristics of EaP migration, and from special surveys which try to capture the irregular part.

Fig. 2.1 - Stock of residence permits for EaP countries, 1999-2011

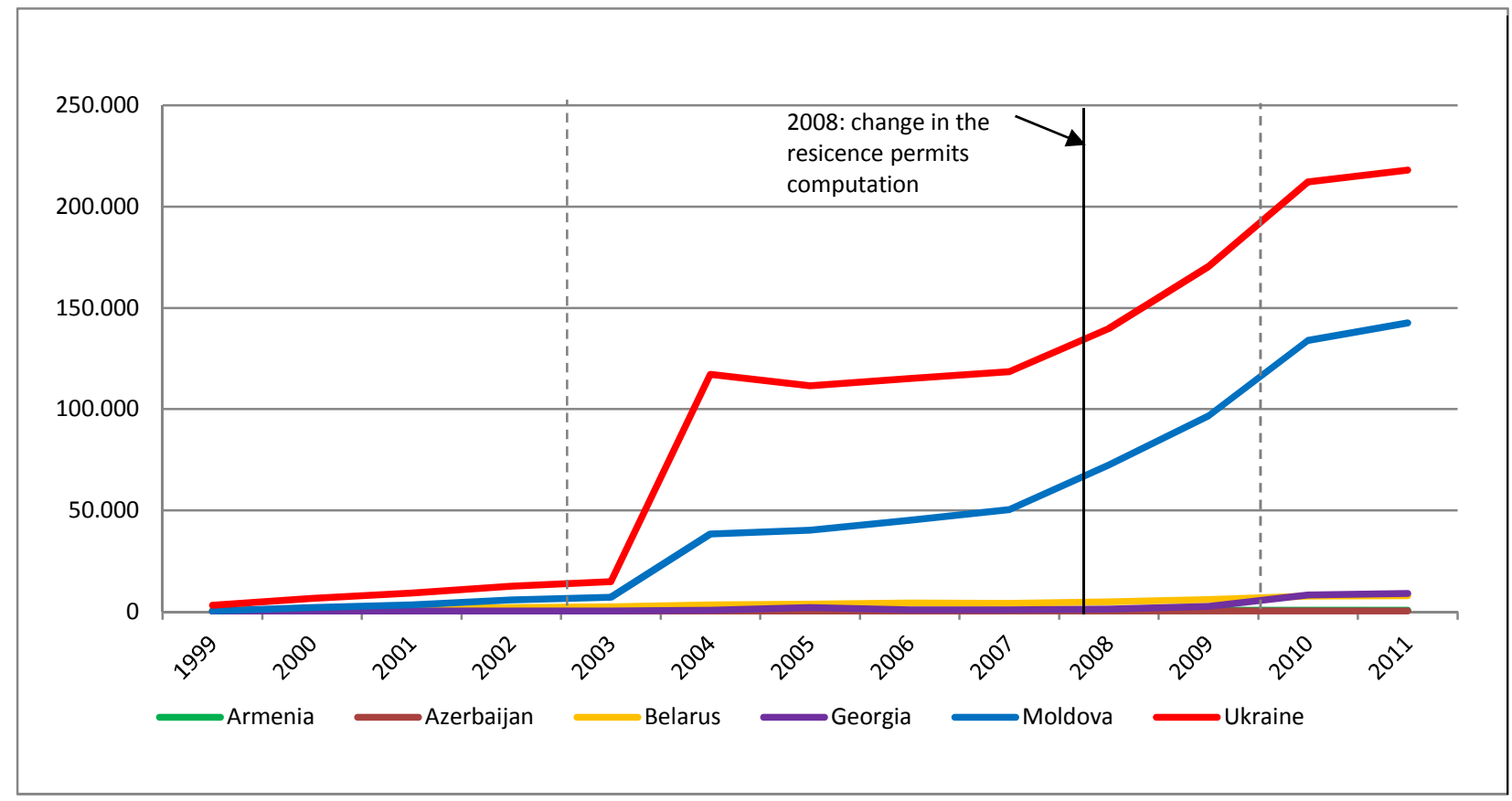

Source: Own elaborations based on Istat, Residence Permits (data from the Home Office).

Notes: The dotted lines correspond to the amnesties (2002, 2009 only for domestic workers), while the continuous lines correspond to revisions in the residence permits computation (see Annex).

\subsection{Quantities}

After the first wave of Romanians, the second wave included migrants from Ukraine and shortly after from Moldova, who were followed by very limited numbers of migrants from the other EaP countries: Armenia, Azerbaijan, Belarus and Georgia. Only Moldovans and Ukrainians have sizeable numbers; 142,000 and 218,000, respectively (data from Istat, Residence Permits. See figure 2.1).

If we consider the residence permit data (excluding migrants from the European Union), immigrants from EaP countries account for 10 per cent of the foreign population in Italy, of which Ukrainians account for 6 per cent and Moldovans 4 per cent. It is a very small percentage of the Italian population: immigrants from EaP countries stand at only 1 per cent.

Emigrants are instead, an important share of the population in the countries of origin, especially in the case of Moldova where emigrants are estimated at 25 per cent of total population, with about 5 per cent of these in Italy. For the Ukraine, estimates report 10 per 
cent of the total population but registered numbers are no more than 3 per cent. 5 In both cases Italy has grown in importance as a destination country in the last five years, ${ }^{6}$ and now is the main EU destination country, and overall second only to the Russian Federation.7

Tab. 2.1 - Foreign people from EaP countries as a percentage of total immigrants and of the Italian population, residence permits and foreign resident population, 2011

\begin{tabular}{|l|lll|lll|}
\hline & \multicolumn{4}{|l|}{ Residence permits } & \multicolumn{4}{l}{ Foreign resident population } \\
\cline { 2 - 7 } & Number & $\begin{array}{l}\text { \% of tot. } \\
\text { immigrants }\end{array}$ & \% on Italian pop. & Number & $\begin{array}{l}\text { \% of tot. } \\
\text { immigrants }\end{array}$ & \% on Italian pop. \\
\hline Armenia & 712 & 0.02 & 0.00 & 666 & 0.01 & 0.00 \\
\hline Azerbaijan & 377 & 0.01 & 0.00 & 324 & 0.01 & 0.00 \\
\hline Belarus & 7,819 & 0.22 & 0.01 & 6,975 & 0.15 & 0.01 \\
\hline Georgia & 9,031 & 0.26 & 0.24 & 6,520 & 0.14 & 0.22 \\
\hline Moldova & 142,583 & 4.03 & 0.24 & 130,948 & 2.87 & 0.33 \\
\hline Ukraine & 218,099 & 6.17 & 0.36 & 200,730 & 4.39 & 0.57 \\
\hline Total EaP & 378,621 & 10.71 & 0.62 & 346,163 & 7.57 & 1.60 \\
\hline Romania & & & & 968,576 & 21.19 & 7.54 \\
\hline Total immigrants & $3,536,062$ & & 5.83 & $4,570,317$ & & \\
\hline Italian pop. & $60,626,442$ & & & $60,626,442$ & & \\
\hline
\end{tabular}

Source: Own elaborations based on Istat, Residence permits and Resident population

Notes: The foreign population is smaller according to the residence permits data because people from the European Union $(1,334,820$ of the Resident population) are not included.

\subsection{Gender}

The gender composition of national groups immediately reveals different immigration patterns. Contrary to the general gender balance achieved through family reunification which for example has significantly increased the share of women among Moroccans and of men among Filipinos women outnumber men among EaP migrants, with 80 per cent among Ukrainians and 90 per cent for Georgians.
Fig. 2.2 - Gender structure for EaP countries, compared with Russian Federation and total immigrants, 2011

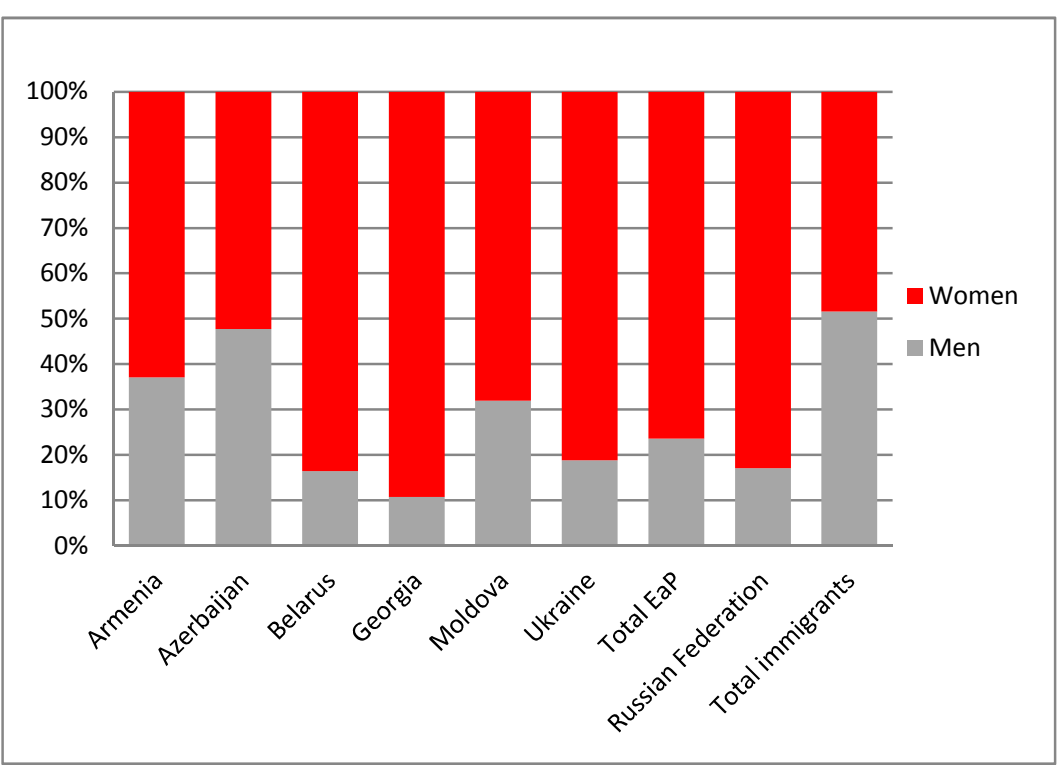

Source: Own elaborations based on Istat, Residence permits

\footnotetext{
5 See ETF, 2009.

${ }^{6}$ According to the information reported in the Soderkoping Process for 2006 in Leončikas and Žibas (2009).

$7 \mathrm{http}: / /$ www.carim-east.eu/90o/moldovan-emigration-stocks-residing-in-the-european-union-by-countryof-residence-most-recent-data-circa-2010/
} 
Focusing on the largest communities of Moldovans and Ukrainians, the sex ratio suggests different migration plans - Moldovans have a more balanced composition, with consequences for their localisation.

\subsection{Age}

For the two largest groups, Moldovans and Ukrainians, detailed information on the age composition is available. Figure 2.3 shows the age distribution of both immigrants and natives. While 20 per cent of natives are aged 65 or older, the total migrant population is younger (see figure 2.3) and has more children.

EaP communities present two different models: Ukrainians are mainly female, older and aged 50-55; Moldovans have a more permanent and settled model of migration, the mode of their distribution is in the age bracket 30-34, and they are younger than the average foreign population ${ }^{8}$.

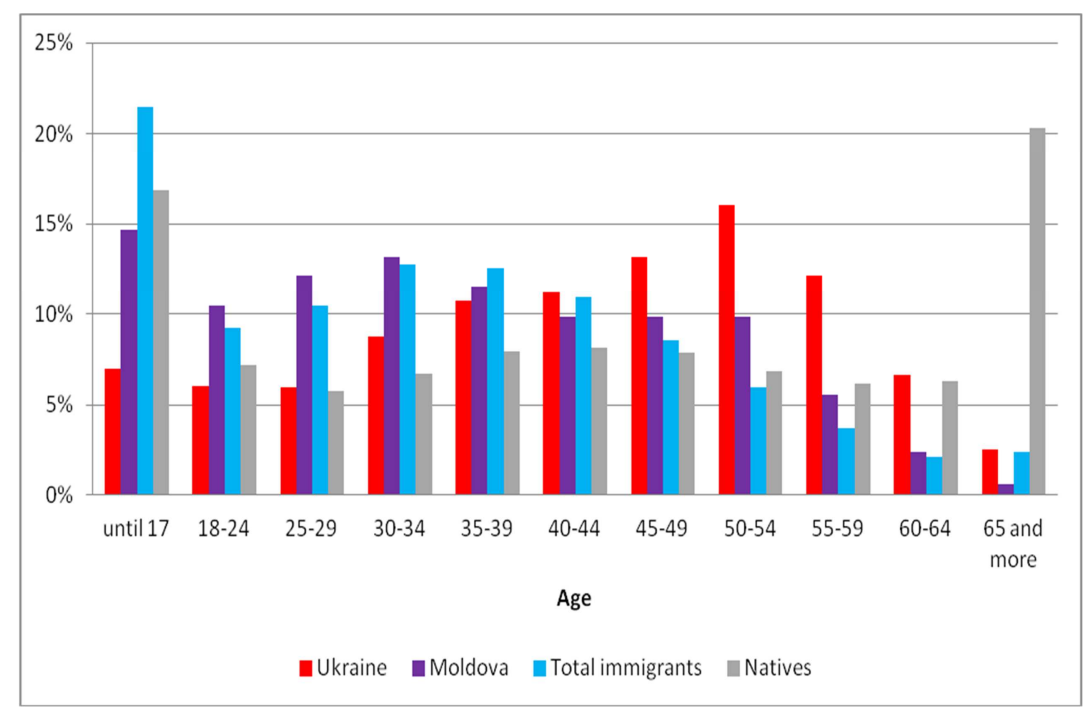

Source: Own elaborations based on Istat, Residence Permits (Home Office data).
Fig. 2.3 - Age structure of immigrants from Moldova and Ukraine, compared with total immigrants and Italian, 2011.

\subsection{Territorial dispersion}

In general, the migrant population is strongly concentrated in northern Italy (64.48 per cent), which is more industrialised. However, migrants from EaP countries are distributed all over the country. Men from Moldova work mainly in Emilia Romagna, and Ukrainians have a tradition of arriving in (and often keeping strong ties with) Campania. Belarusians and Georgians arrive in the south, where it is easy to find informal work and then they move to the centre and to the north, where higher quality job options are available.

\footnotetext{
${ }^{8}$ See Marchetti and Venturini (forthcoming).
} 
Azerbaijanis, though in small numbers, are concentrated in the north or in central Italy and Armenians in the north-east, where the old diaspora has settled.

Tab. 2.2 - Regional distribution of immigrants from EaP countries, 2008

\begin{tabular}{|c|c|c|c|c|c|}
\hline \multicolumn{2}{|c|}{ Armenia $(n=426)$} & \multicolumn{2}{|c|}{ Azerbaijan $(n=252)$} & \multicolumn{2}{|c|}{ Belarus $(n=4,265)$} \\
\hline Area & $\%$ & Area & $\%$ & Area & $\%$ \\
\hline North-west & 19,0 & North-west & 47,6 & North-west & 23,0 \\
\hline North-east & 33,3 & North-east & 16,3 & North-east & 25,2 \\
\hline Centre & 36,4 & Centre & 30,6 & Centre & 26,6 \\
\hline South & 8,2 & South & 2,4 & South & 19,6 \\
\hline Islands & 3,1 & Islands & 3,2 & Islands & 5,7 \\
\hline Regions & $\%$ & Regions & $\%$ & Regions & $\%$ \\
\hline Lazio & 18,5 & Lombardy & 32,5 & Lombardy & 15,5 \\
\hline Lombardy & 15,5 & Lazio & 13,5 & Emilia Romagna & 11,7 \\
\hline Friuli Venezia G. & 13,8 & Piedmont & 13,1 & Lazio & 10,7 \\
\hline \multicolumn{2}{|c|}{$\operatorname{Georgia}(n=1,012)$} & \multicolumn{2}{|c|}{ Moldova $(n=68,591)$} & \multicolumn{2}{|c|}{ Ukraine $(n=132,718)$} \\
\hline Area & $\%$ & Area & $\%$ & Area & $\%$ \\
\hline North-west & 21,0 & North-west & 23,6 & North-west & 24,3 \\
\hline North-east & 30,4 & North-east & 51,5 & North-east & 24,5 \\
\hline Centre & 29,0 & Centre & 21,0 & Centre & 20,6 \\
\hline South & 16,0 & South & 3,6 & South & 28,8 \\
\hline Islands & 3,6 & Islands & 0,4 & Islands & 1,7 \\
\hline Regions & $\%$ & Regions & $\%$ & Regions & $\%$ \\
\hline Emilia Romagna & 17,5 & Veneto & 28,3 & Campania & 20,8 \\
\hline Lombardy & 15,5 & Emilia Romagna & 18,7 & Lombardy & 18,2 \\
\hline Lazio & 14,2 & Lombardy & 14,2 & Emilia Romagna & 12,5 \\
\hline
\end{tabular}

Source: Own elaborations based on Istat, Foreign resident population.

Notes: Percentage of the total foreign population resident in Italy from that country of origin.

\subsection{Reason for migration}

Family reunification plays a less significant role on for $\mathrm{EaP}$ migrants: 25 per cent of Ukrainians and 35 per cent of Moldovans applies for a residence permit for family reasons compared to 47 per cent for total immigrants (see Figure 2.4). It varies for men and women, with family reunification the lowest for Ukrainian women, at only 20 per cent.
Fig. 2.4 - Rate of residence permits by reasons, 2010

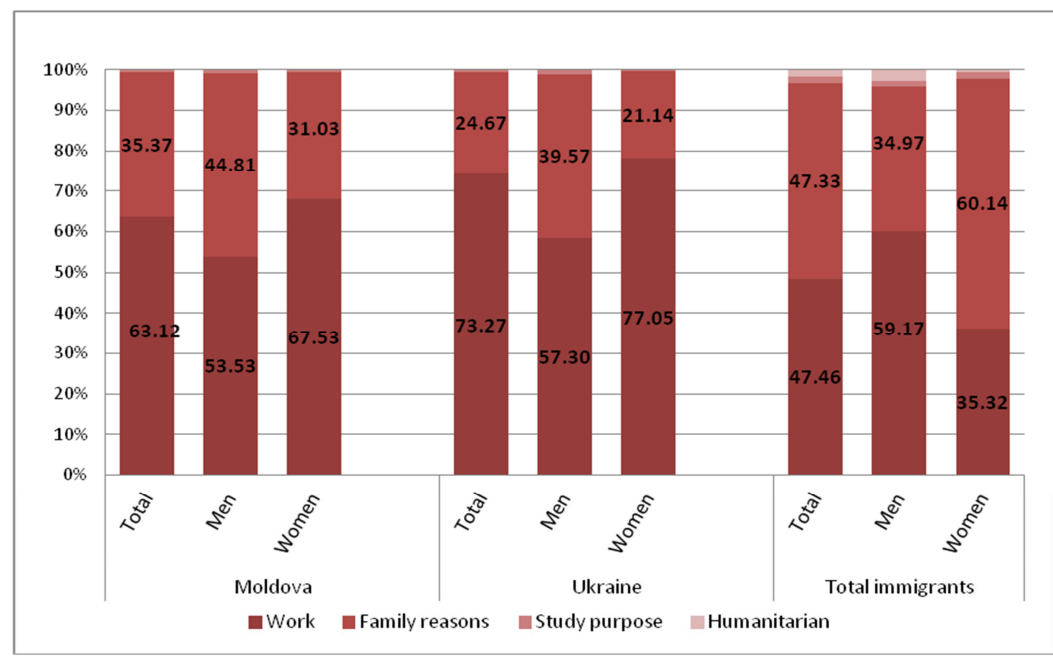

Source: Own elaborations based on Istat, Residence Permits (Home Office data). 


\subsection{Sectors of employment}

The different demographic composition of the inflows from EaP countries suggests a difference in the migratory project of each national group. With the Labour Force Survey (LFS) from Istat migrant occupations by sector can be analysed.

\section{Fig. 2.5 - Sectors of employment by gender, total immigrants and EaP countries,} 2011
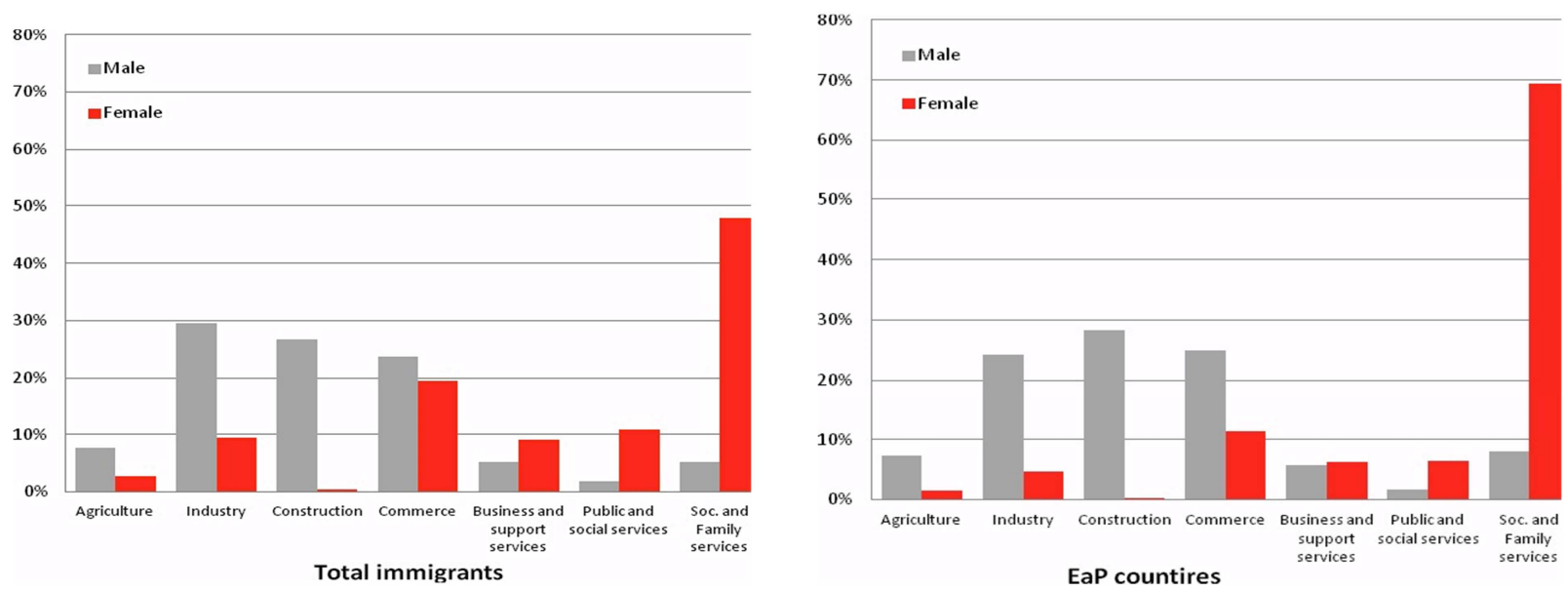

Source: Own elaborations based on Istat, Labour Force Survey (LFS) 2011 - second quarter.

Notes: Commerce includes commerce, hotel, restaurants, transport and communications; business services include financial intermediation and business and professional services; public and social services include public administration, health, education, and other social services.

This, of course, is more representative for large groups, such as Moldovans and Ukrainians, and less for others.

In Italy, industry is generally dominated by men (55 per cent), while social and family services by women (48 per cent). However, for the case of EaP migrants these proportions change: the rate of males employed in the industrial sector is lower, while the proportion of women in the social and family service is higher at 73 per cent.

It is important to underline that the sector of social and family service is, however, not internally homogeneous, as it includes two different types of workers: cleaners and live-out caregivers who work by the hour, and live-in caregivers who live in the house of their employers - taking care of the house, children and elderly. The latter are often referred to as badanti in Italy. Those who want to settle in the country and then reunify with their family tends to do this work for the initial phase of life in Italy. These are, indeed, two very different types of jobs which belong to the same sector, but which involve very different migration patterns. 
Ukrainian women who are alone, without their family and are already middle-aged tend to have a temporary migration intention9. They come to Italy to accumulate savings (often to pay for the education of their children) and return as soon as they have saved enough.

Moldovan migration started after the Ukrainian migrants, as the data on entrance and length of stay show. On arrival, they had the same migratory pattern as Ukrainians but they rapidly changed, emulating rather Romanian women who had started to reunify their family and to move from live-in to live-out care work or to other jobs in the service sector. The difference in the trajectories of Moldovans and Ukrainians is that Moldova - in comparison to Ukraine - is less attractive as a permanent home. In fact, the income per capita - which is not a good proxy for wages available but does provide an indicator of wealth - is 20 per cent of the EU15 average in Moldova versus 35 per cent in Ukraine. ${ }^{10}$

\subsection{Temporary and permanent migration projects}

The LFS shows the time of arrivals only for Ukrainians and Moldovans, and replicates the information on the time of the inflows. Of particular interest is the question concerning the path followed by interviewees. To the question "Have you always been in Italy?", 98 per cent of Ukrainians and 99 per cent of Moldovans answered positively, in line with the overall migrant population (98.5 per cent). This highlights how Italy is not a transit country, but rather the main destination for these migrant workers. This fact is not enough, however, to explain whether their migration is temporary or permanent.

\subsubsection{The case of EaP migrants in Lombardy}

Thanks to a smaller data set ${ }^{11}$, which ISMU (2011b) gathered for migrants in the northern Italian region of Lombardy, we will be able to get a better grasp of the difference between the migration projects of the two groups. Lombardy is one of the regions with the highest percentage of total immigrants (see Table 2.2).

With regard to demographic characteristics, the general gender structure corresponds to the gender structure of Moldovans and Ukrainians. Age structure (even if Moldovans are slightly older than in the national sample), as well as educational levels ${ }^{12}$ and years since

9 The only paper which measures the re-migration decision for migrants (Venturini and Villosio, 2008; Faini, Strom, Venturini and Villosio, 2009) uses the social security data set which well covers employment in the private industrial and service companies but not female employment in the family services.

${ }^{10}$ According to the World Bank World Development Indicators, gross domestic product (GDP) in purchasing power parity in 2008 was 6,070 USD in Armenia, 8,765 in Azerbaijan, 12,261 in Belarus, 4,897 in Georgia, 2,925 in Moldova and 7,271 in Ukraine -, as a comparison, it was 17,625 in Poland and 16,139 in the Russian Federation. See for instance ETF, 2011, p.10.

${ }^{11}$ The data set for EaP nationals other than Moldovans and Ukrainians is unfortunately too small. The ISMU data have the advantage of containing information on irregular migrants and on co-resident workers which are excluded from the ISTAT LFS and some interesting questions for the analysis of permanent versus temporary migration.

${ }^{12}$ Apparently the share of Moldavian immigrants with a tertiary education is much higher and the share with an education up to the lower secondary level is lower. Yet, it is important to note that we proposed data on the overall population (starting from birth), while the ISMU sample excludes minors (younger than 15 years 
migration are also similar. An interesting feature of Moldovans and Ukrainians is the low share of unmarried people (17 per cent and 25 per cent) compared to other immigrants (more than 30 per cent), and the higher share of widowers or separated/divorced people, probably depending on the high share of older immigrants and women.

An important characteristic concerns their accommodation: 26 per cent of Moldovans and 37 per cent of Ukrainians live at their place of work, mainly because they are live-in carers - information missing from official statistics (see Table A.5, in the Annex).

When it comes to the analysis of temporary and permanent migration, people from Eastern Europe and CIS countries are more likely to move temporarily. Within these same groups, however, there are some differences. In particular, Moldovans move for the longterm, sometimes permanently, while most Ukrainians intend only to stay temporarily.

The first interesting question in the ISMU dataset is the likelihood of returning home: almost 87 per cent of Moldovans and Ukrainians do not plan on moving. Yet, Ukrainians are the group with the strongest intention to head back to their country (8.5 per cent), followed by Romanians (8.2 per cent), but also Moldovans have a significant percentage (7.3 per cent) (see Table 2.3). The number of children in Italy, with respect to the total number of children, is very telling: more than 70 per cent of Ukrainians and Moldovans have no children in Italy but only in the country of origin - a percentage much higher than among other immigrants groups (see Tables A.6 and A.7, in the Annex).

Tab. 2.3 - Intention to move of immigrants in Lombardy, by country of origin, 2010

\begin{tabular}{|l|l|l|l|l|l|l|l|l|l|l|l|l|l|l|l|}
\hline $\begin{array}{l}\text { IXX. Do you intend to move } \\
\text { elsewhere within next 12 months? }\end{array}$ & Alb & Rom & Ukr & SrL & Chin & Phil & Ind & Pak & Egy & Mor & Sen & Ecu & Per & Mold & Lomb \\
\hline No & 92.9 & 83.9 & 87.5 & 86.5 & 90.3 & 93.4 & 93.9 & 88.9 & 85.4 & 82.7 & 81.0 & 90.6 & 91.4 & 86.9 & 86.9 \\
\hline Yes,to another town in Lombardy & 1.0 & 3.1 & 1.5 & 3.9 & 2.6 & 0.4 & 1.4 & 2.0 & 3.1 & 4.3 & 6.1 & 2.9 & 2.3 & 5.2 & 2.8 \\
\hline Yes,to another Italian town & 0.6 & 1.0 & 1.0 & 0.3 & 3.0 & 0.5 & 0.6 & 0.7 & 1.4 & 1.9 & 2.0 & 1.6 & 0.3 & 0.6 & 1.3 \\
\hline Yes,to another country & 1.2 & 3.7 & 1.6 & 1.7 & 1.6 & 4.4 & 2.7 & 3.9 & 2.8 & 4.9 & 5.1 & 1.5 & 1.5 & 0.0 & 3.7 \\
\hline Yes, to my country of origin & 4.2 & 8.2 & 8.5 & 7.5 & 2.4 & 1.3 & 1.5 & 4.6 & 7.4 & 6.2 & 5.9 & 3.4 & 4.4 & 7.3 & 5.3 \\
\hline
\end{tabular}

Source: ISMU (2011b) and extensions obtained for the project.

Notes: Some of the percentages do not add up to 100 due to rounding.

However, the most significant variable is the desire for family reunion: 82 per cent of migrants from Ukraine do not intend to apply for reunification with their partner, compared to 48 per cent of Moldovans, as shown in Table 2.4.

The picture that derives from these results reinforces the hypothesis of diversity within Moldovan and Ukrainian migration patterns: more temporary for Ukrainians and more permanent for Moldovans - who even if they miss their country of origin are less prone to return.

old). Since the share of minors, who are still studying, amongst Moldavians is about 15 per cent, the different sample used can explain the dissimilarities. On the contrary, the share of minors in the Ukrainian population is less than 7 per cent, thus differences will be smaller. 
Tab. 2.4 - Intention of family reunion of immigrants in Lombardy, by country of origin, 2010

\begin{tabular}{|l|l|l|l|l|l|l|l|l|l|l|l||l|l|l|}
\hline $\begin{array}{l}\text { XX. (For those with a partner } \\
\text { abroad) Do you intend to ask for } \\
\text { family reunion for your } \\
\text { spouse/partner? }\end{array}$ & Alb & Rom & Ukraine & SrL & Chin & Phil & Ind & Pak & Egy & Mor & Sen & Per & Moldova & Lomb. \\
\hline Yes, within a year & 57.9 & 22,3 & 10,7 & 52,8 & 10,2 & 56,4 & 41,6 & 38,2 & 21,9 & 33,8 & 13,2 & 28,4 & 31,9 & 30,4 \\
\hline Yes, in more than 1 year &. & 5,3 & 7,2 &.. & 39,1 & 17,4 & 16,3 & 25,0 & 18,1 & 33,7 & 30,2 & 32,5 & 19,6 & 21,0 \\
\hline No & 42.1 & 72,4 & 82,2 & 47,2 & 50,7 & 26,2 & 42,1 & 36,8 & 60,0 & 32,5 & 56,6 & 39,1 & 48,5 & 48,5 \\
\hline Total & 100 & 100 & 100 & 100 & 100 & 100 & 100 & 100 & 100 & 100 & 100 & 100 & 100 & 100 \\
\hline
\end{tabular}

Source: ISMU (2011b)and extensions obtained for the project

\subsubsection{EaP migrants in Campania}

When it comes to duration and typology of migratory projects, the comparison between Lombardy in the north and the Campania in the south is particularly relevant. The two regions seem to attract people with two opposite migratory objectives, probably due to the very different economic structure of these two areas, and consequently of the labour opportunities that they can offer migrants. In this sense, the geographical asymmetry that typifies the Italian economy determines the mobility of migrants between different parts of Italy.13

The migrant population in Campania has increased fivefold in the last twenty years. Yet, one has to consider that, as in all southern Italian regions there is less migration than in the north of Italy, for example, Lombardy. Similarly, the activity rate of migrants, although higher than the local Italian population, is lower than in the north of Italy due to reduced employment opportunities in this area. The sectors of employment for migrants are mainly trade and services (72 per cent), industry (23.6 per cent) and finally agriculture (6.3 per cent).

A remarkable feature of migration in this region is its temporariness. Campania is a space of transition: the ideal place for the first period in Italy, thanks to a significant informal economy and opportunities for daily employment, especially in agriculture. From here, migrants can head off towards other areas, in search of a more stable employment and living conditions. This is demonstrated by the fluctuation in the number of regular residents, which reaches a peak at the time of a regularisation but decreases in the following years. The data suggest that after having regularised their position, migrants do actually prefer to move to other regions (or abroad). ${ }^{14}$ An exception to this trend is represented by those who are employed in the care and domestic sector who, in comparison with others, have a more secure and stable employment condition.

Interestingly, Ukrainians have the greatest presence in this region, at 37,391. The other EaP nationals in this region are Moldovans, whose presence is, however, not particularly remarkable (1,573 in 2011). As in other parts of Italy, Ukrainians in Campania are

\footnotetext{
${ }^{13}$ See de Filippo and Strozza (2011).

14 For instance, in the province of Napoli alone of 33,081 foreign nationals in 2004 that regularised their position through the 2002 amnesty, only 8,706 were still there in 2007.
} 
predominantly employed in the domestic and care sector. Thus, they have a relatively stable permanence in this area.

In the context of the same ISMU survey to which we refer for Lombardy, Cesareo and Blangiardo (2009) conducted a recent study on migrants in the area of Naples, which helps us to understand the mobility profile of the Ukrainians living in this area. From a demographic point of view, the survey reports a strong gender asymmetry among Ukrainians, who are 84.9 per cent women in Naples. They are also older than the other groups (in the city of Naples their average age is 41.7), predominantly married but generally living apart from their spouses and children. They are also better educated:37.5 per centhave a university degree.

Ukrainians in Campania number among the migrants whose arrival in the region dates further back in time, with many having lived in the region for more than 10 years, and an average of seven. This is probably due to the strong connection of Ukrainians with this territory on the basis of the traditional connection between the port of Odessa and Naples.

The picture is, however, not very clear in Campania because Ammaturo et al. (2010) find that Ukrainians in Campania express the intention of long-term migration, with only 64 per cent planning to rejoin with their family. Certainly for the moment, the reunited family share is very limited.

\subsection{Irregular and undocumented migrants}

\subsubsection{Irregular migration to Italy}

The increase in regular migrants in Italy has jumped slightly after the amnesties, as can be seen in Figure 1.1. In fact, a huge part of regular migration to Italy is composed of previously irregular migrants, as pointed out by the Ministry of Interior (Ministero dell'Interno, 2007).

One way to have an idea of the size of illegality is through the number of regularised immigrants, often fewer than expected. In the 1980s and 1990 s the ratio of regularised immigrants to total immigrant was of 30 per cent (1987), 45 per cent (1991), 27 per cent (1996) and 18 per cent (1998) (Del Boca and Venturini, 2005). A survey of year 2000 carried out by Strozza reported 465,000-546,000 illegal immigrants in 1994 and 176,000295,000 in 1998.

In more recent years the percentage of irregular immigrants is even lower, according to the estimates carried out by ISMU and published every year in their report on migration.

Tab 2.5 -Irregular migration to Italy, 2005-2011

\begin{tabular}{|c|c|c|c|c|c|c|c|c|c|c|c|c|}
\hline & \multicolumn{2}{|c|}{2005} & \multicolumn{2}{|c|}{2007} & \multicolumn{2}{|c|}{2008} & \multicolumn{2}{|c|}{2009} & \multicolumn{2}{|c|}{2010} & \multicolumn{2}{|c|}{2011} \\
\hline & & $\%$ & & $\%$ & & $\%$ & & $\%$ & & $\%$ & & $\%$ \\
\hline Regular & $2,817,000$ & & $3,633,000$ & & $3,677,000$ & & $4,416,000$ & & $4,880,000$ & & $4,961,000$ & \\
\hline Irregular & 540,000 & 16.1 & 349,000 & 8.8 & 651,000 & 15.0 & 422,000 & 8.7 & 454,000 & 8.5 & 443,000 & 8.2 \\
\hline
\end{tabular}


Irregular migration fluctuates up and down, as shown by fig 2.6, which is a consequence of frequent amnesties, that creates an attraction-effect just before the amnesty followed by a decrease immediately after (Cesareo and Blangiardo, 2009).

An additional cause of the reduction in illegal migration is the enlargement of the European Union in 2007 which let Romanian and Bulgarian European citizens move freely while, before, 33-35 per cent of them had an illegal presence

According to Cesareo and Blangiardo (2009) the main region of origin of irregular migrants to Italy today is Sub-Saharan Africa (15.3 per cent of established immigrants), while Eastern Europe stands at only 5.8 per cent, reflecting in large part the positive effects of European enlargement. However, when comes to non-EU Eastern countries the ratio exceeds 10 per cent.

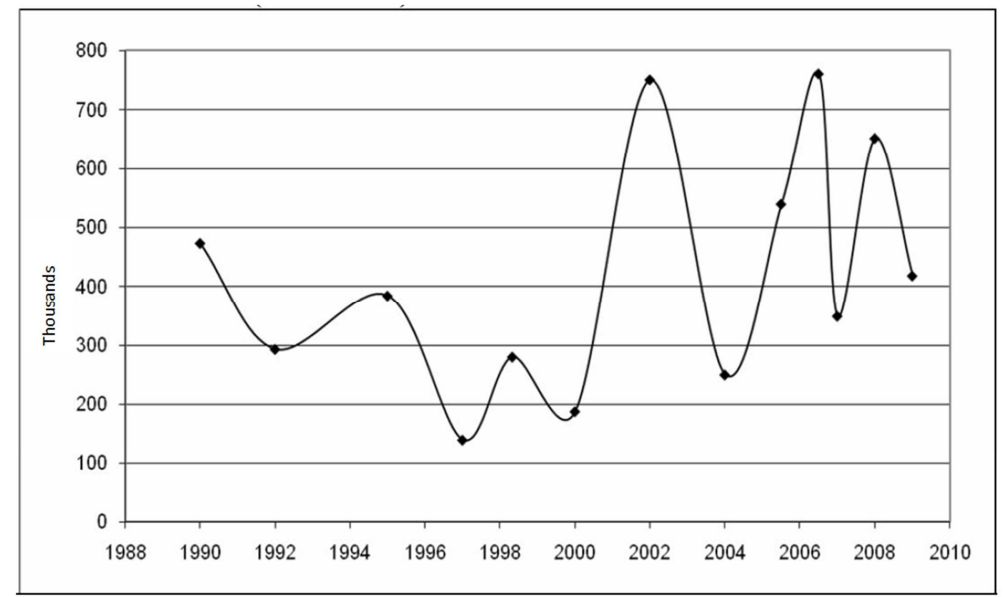

Fig. 2.6 - Estimated number of irregular migrants living in Italy. Years 1988-2010 (Thousands)

Source: Cesareo and Blangiardo, 2009.

In particular, irregular immigrants from Ukrainians make up 13.9 per cent of resident immigrants, and $\mathbf{1 4 . 5}$ per cent are from Moldova. In this ranking, Ukraine is the third country in absolute terms (28,000 irregular immigrants, 6.7 per cent of all irregular migrants) and Moldova the sixth (17,000, 4.1 per cent of all irregular migrants).

Looking at the demographic composition, irregular immigrants are more likely to be male (more than 6o per cent) and younger, and more likely to be settled in the south than regular migrants (Fasani, 2008).

Despite the political usage of the fight against illegal migration, of the 454,00o irregular migrants estimated in 2010, only 46,516 were found by the police, and only 20,287 moved out of Italy (Caritas/Migrantes, 2011). This underlines the complexity of the issue and the connection between the resources invested in control and the real willingness to fight illegality. 


\begin{tabular}{|l|cr|}
\hline & Thousands & per cent \\
\hline Morocco & 59 & 14.1 \\
Albania & 54 & 12.9 \\
Ukraine & 28 & 6.7 \\
P.R. of China & 23 & 5.5 \\
Senegal & 18 & 4.3 \\
Moldova & 17 & 4.1 \\
Tunisia & 16 & 3.8 \\
Philippines & 15 & 3.6 \\
India & 14 & 3.3 \\
Egypt & 14 & 3.3 \\
\hline 1O major countries & 258 & 61.6 \\
All h.m.p. countries & 418 & 100.0 \\
\hline
\end{tabular}

Tab. 2.6 - Foreign population originating from heavy migrationpressure countries irregularly established in Italy. Major nationalities. Absolute and percent values

Source: Cesareo and Blangiardo, 2009

\subsubsection{The main causes of illegal migration}

Illegal migration can be divided into over-stayers and non-authorised entrance. This is mainly caused by the following characteristics of the Italian context ${ }^{15}$ :

1. Geography: the long frontiers of Italy, which are also close to unstable and less developed areas, facilitate illegal migration, even if this is not the main route for migrants from EaP countries, who tend to arrive by land;

2. Economy: the large underground economy (20 per cent of official GDP according to Istat, 2010) means that irregular immigrants can find jobs while waiting for an amnesty (see point 3). This combines with the structural and strong demand for foreign workers, that provides higher demand than allowed for by regular migration. The main sectors of irregular work are agriculture (24 per cent in 2009), construction (10 per cent), domestic and care work (up to 50 per cent) and trade and hotel (18.7 per cent) (data from Istat, 2010);

3. Migration policy: on the one hand, the lack of legal access to the Italian labour market forces migrants to look for alternatives; on the other hand, the frequencies of amnesties are themselves a pull factor in new illegal migrant flows. In 2002, through these measures, 101,651 Ukrainians and 29,471 Moldovans sought to regularise their position. The outcomes of the 2009 procedure are not clear yet, but in Table 2.7 one may find the number of EaP nationals who have made an application.

15 See Fasani (2008). 
Tab. 2.7 - Applications from EaP nationals to the last Italian amnesties

\begin{tabular}{|c|c|c|c|c|}
\hline & \multicolumn{4}{|c|}{ Amnesties } \\
\hline & \multicolumn{2}{|l|}{2002} & \multicolumn{2}{|l|}{2009} \\
\hline Countries & a.v. & $\begin{array}{l}\text { Over } 100 \\
\text { regulars }\end{array}$ & a.v. & $\begin{array}{l}\text { Over } 100 \\
\text { regulars }\end{array}$ \\
\hline Ukraine & 101,651 & 655.4 & 37,211 & 21.8 \\
\hline Moldova & 29,471 & 335.0 & 26,605 & 27.6 \\
\hline Georgia & n.a. & n.a. & n.a. & n.a. \\
\hline Belarus & n.a. & n.a. & n.a. & n.a. \\
\hline Armenia & n.a. & n.a. & n.a. & n.a. \\
\hline Azerbaijan & n.a. & n.a. & n.a. & n.a. \\
\hline
\end{tabular}

Source: Own elaboration based on Istat (2004) and Ministero dell'Interno (2010)

\subsubsection{Estimates and methodology}

To have an idea of the size of illegality one way is to look at the number of regularised migrants through the amnesties, as in Table 2.7 (see as example Strozza in Del Boca and Venturini, 2005).

ISMU, for instance, carries out a regional survey in Lombardy each year (8-9,000 interviews), used to produces national estimates, and carried out a national survey

in 2005 (30,000 interviews) and 2009 (12,000 interviews). The main issue is the absence of information on undocumented migrants, which gets in the way of a truly representative sample, causing likely biases. ISMU overcomes this problem by applying the method "by aggregation centres or environments", which randomises between identified centres of social interaction of migrants ${ }^{16}$.

\subsubsection{Irregular migration from Ukraine and Moldova}

The EMN report (2011) reveals how many Ukrainians and Moldovans were found to be illegally present in Italy. But as we have seen before this is only a small part of the total for irregular migration. According to the ISMU estimates 28,000 Ukrainians and 17,000 Moldovans were illegally present in Italy. If we add this to the numbers for regular migrants we find that, in 2009, 198,440 Ukrainians lived in Italy and 113,564 Moldovans. To give an idea though of how the data on irregular migration vary consider that according to Bocale and Manzi (2010), who refer to different sources, the total number of Ukrainians working in Italy in 2006 was about 324,000. As to Moldova, the IOM country profile claims that 38 per cent of Moldovans migrated to Europe illegally, and that 44 per cent live there without the proper papers (OIM, 2008a). If the irregular agricultural sector does not concern migrants from EaP, then construction is the main sector of employment for male migrants, especially those from Moldova.

The domestic sector, in which most women from EaP countries are employed, is characterised by a large number of irregular workers, especially in the case of co-residence.

Tab. 2.8 - Ukrainians and Moldovans found to be illegally present and ordered to leave

\begin{tabular}{|c|c|c|c|c|c|c|c|c|}
\hline \multirow[b]{2}{*}{ Countries } & \multirow[b]{2}{*}{2008} & \multirow[b]{2}{*}{2009} & \multirow[b]{2}{*}{2010} & \multicolumn{4}{|c|}{2010} & \multirow{2}{*}{$\begin{array}{c}\text { Var. per cent } \\
\text { 2008-2010 }\end{array}$} \\
\hline & & & & per cent $F$ & minors & complaint & per cent & \\
\hline Ukraine & 2,090 & 1,480 & 1,460 & 29.4 & o & 330 & 15.8 & -30.1 \\
\hline Moldova & 2,230 & 1,485 & 1,110 & 11.7 & 0 & 240 & 10.8 & -50.2 \\
\hline
\end{tabular}

Source: EMN Italy. Elaboration Eurostat data

\footnotetext{
${ }^{16}$ Further details of this method can be found in Cesareo and Blangiardo (2009) and in Fasani (2008).
} 
This is due to the difficulties in controlling their presence and to the advantages both for the family and for the worker. Irregular employment reduces the costs for the family, since they do not pay social contributions. But it is also reduces the very complex bureaucratic procedure. In addition the migrants are not interested in pensions and prefer to get more money.

A minority of women from Eastern Europe, especially Ukraine, work as farmhands in southern Italy. This phenomenon is not traceable in regular statistics, since the relevant workers are undocumented. However, it is described by a report from INEA (see Cicerchia and Pallara, 2009), and from MSF (2005). It concerns a new flow of immigrant women from Eastern Europe arriving as seasonal agricultural workers and overstaying. All the irregular workers and particularly the women are in a very weak position and they are frequently exploited (Caritas/Migrantes, 2011).

\subsubsection{The routes of irregular migration from EaP countries}

Tab. 2.9 - Type of border where refused entry

\begin{tabular}{|l|l|l|l|}
\hline & $\mathbf{2 0 0 8}$ & $\mathbf{2 0 0 9}$ & $\mathbf{2 0 1 0}$ \\
\hline Land & 1,820 & $:$ & $:$ \\
\hline Sea & 1,445 & 1,190 & 1,270 \\
\hline Air & 3,135 & 2,510 & 2,945 \\
\hline Total & 6,405 & 3,700 & 4,215 \\
\hline
\end{tabular}

Source: EMN Italy. Elaborations on Eurostat data.
The large inflow of tourists to Italy means that is easy for EaP migrants to enter the country, migrants who simply stay on after the expiry of visas. In fact, Caritas/Migrantes (2011) highlights the fact that, despite most of the attention being on people arriving illegally in Italy by sea as Table 2.8 points out, the majority of irregular migrants are overstayers.

The routes used by irregular migrants from EaP countries to Italy are the same from the Black Sea Region, described in the IOM report (2008b):

- The Balkan Route: the overland route from the Middle East and Asia via Turkey to Bulgaria, Romania, Hungary, Slovakia and the Czech Republic. A subroute through Albania or Serbia and Montenegro to Italy or through the western Balkans to Slovenia and on to Italy or Austria.

- The Central and Eastern European Route: starts in the Russian Federation, Belarus or Ukraine passing through Belarus, Poland or Czech Republic to Austria or Germany or through Ukraine to Slovakia or Hungary.

- The Baltic Route: from the Russian Federation via the Baltic states to Poland through to Germany or the Czech Republic.

\subsection{Conclusion}

In this section, we described the migrants' profiles of the EaP countries of origin. EaP migrants go to make up 10 per cent of the non-EU foreign population in Italy $(7.5$ per cent if we also consider immigrants from the European Union), with a large female bias and a tendency to be older than other migrant group. Some differences are evident between Ukrainian and Moldovan immigrants (the two most important groups of migrants from 
EaP countries to Italy), because of their different migration projects, temporary for Ukrainians and permanent for Moldovans. Moldovans have, in fact, a slightly more balanced gender structure, and even if older than other migrants, the median age is 30-35 (for Ukrainian it is 50-55).

Both groups are mainly employed in the domestic and care sector, thus they tend to depend on labour stay permits. But a higher percentage of Moldovans also have family reunification permits. The last section was dedicated to irregular migration, a consequence of the large underground economy in Italy and of migration policy there. About 14 per cent of established immigrants from Ukraine and Moldova are estimated to be irregular, compared to 8-9 per cent of all immigrants. This may partially be due to the peculiarities of the domestic sector that reduces the probability of being found irregular. 


\section{Employment and labour market}

In this section we focus on labour-market outcomes for foreign nationals from EaP countries, comparing them to the dominant group from other immigration countries (Romania, the Philippines, Morocco etc), in terms of the total number of migrants and the total numbers of natives. The labour market performances of EaP nationals will also be described, in the following section, and the relations between the migrants and the local labour force. We use the Italian LFS elaborated by Istat (second quarter of 2011) compared with the 2008 release that had a special focus on foreign labour.

Since this is a sample survey, small groups are underrepresented and are thus, unfortunately, excluded from the analysis. The sample size for Belarus is very small (18 units), but we decided to include it in the tables, although it will not be object of comparison. The migration dynamic of Belarus and Ukraine is very similar (the first waves arrived in the 1990s and increased at the beginning of the 2000s), the gender structure is the same, and the age structure is also similar ${ }^{17}$. Georgian immigrants, even if they arrived a little later, like Moldovans, have the same gender structure as Ukrainian migrants. In conclusion, we suggest that immigrants from Belarus and Georgia have a similar migration pattern to Ukraine, and not to Moldova, where the male component is larger, and which is similar to Romanian migration. Migrants from Armenia and Azerbaijan are not a mass flow and they melt away in the labour force statistics because they are not concentrated but rather they are small frequently very highly-skilled elites.

There is a (tiny) difference between the number of foreign-born people and foreign people ${ }^{18}$, and we decided to use the second variable, in order to avoid mistakes due to intra-migration in the concerned regions of origin. Moreover, since migration from EaP countries is quite recent, foreign-born people who obtained Italian citizenship are few (69 people from all EaP countries).

\subsection{Employment and unemployment rate}

As the previous section points out (see Figure 2.4), immigrants from EaP countries came to Italy for labour purposes, above all. Then, not surprisingly, their activity rate ${ }^{19}$ of 80 per cent is higher than that for the all foreign nationals (71 per cent) ${ }^{20}$, with the exception of the Philippines, and, of course, higher than that for Italians (61 per cent), as in Table 3.1.

What drives up the activity rate is the female participation rate which in some cases is higher than the male. It is also higher than the equivalent rate in other foreign communities with the exception of the Filipinas, who are mainly employed in family services.

Ukrainian women are the main breadwinners, while Moldovan men participate in a significant fashion in the search for employment but have a higher unemployment rate.

\footnotetext{
${ }_{17}$ Data from the Labour Force Survey, not included.

${ }^{18}$ For definitions, see OECD (2010).

19 For labour force on working-age population 15-64 years.

${ }^{20}$ See ISMU (2011).
} 
From 2008, a pre-crisis period, to 2011, the activity rate and employment rate of Italians and, indeed, of all immigrants declined, as the unemployment rate increased. For EaP migrants, namely Ukrainians and Moldovans, the activity rate remains stable or increased, thanks to the rise in the employment of the female segment and thanks to a reduction in their unemployment. While for the male component the unemployment rate increased as among Italians, Romanians and Moroccans.

Tab. 3.1 - Employment status of foreign nationals and nationals, by gender, 2008, 2011. Share of working age population (15-64)

\begin{tabular}{|c|c|c|c|c|c|c|c|c|c|c|c|c|c|c|c|}
\hline & & \multicolumn{3}{|c|}{2008} & \multicolumn{3}{|c|}{2011} & & & \multicolumn{3}{|c|}{2008} & \multicolumn{3}{|c|}{2011} \\
\hline & & $\mathrm{F}$ & M & Tot & $\mathrm{F}$ & M & Tot & & & $\mathrm{F}$ & M & Tot & $\mathrm{F}$ & M & Tot \\
\hline \multirow{3}{*}{ Belarus } & Labour force & 63 & 0 & 63 & 69 & 86 & 72 & \multirow{3}{*}{ Romania } & Labour force & 65 & 85 & 75 & 69 & 88 & 78 \\
\hline & Empl. rate & 29 & o & 29 & 69 & 36 & 72 & & Empl. rate & 58 & 80 & 69 & 59 & 81 & 69 \\
\hline & Unempl. rate & 54 & o & 54 & o & $\mathrm{o}$ & $\mathrm{o}$ & & Unempl. rate & 11 & 6 & 8 & 14 & 8 & 11 \\
\hline \multirow{3}{*}{ Moldova } & Labour force & 77 & 87 & 80 & 78 & 84 & 80 & \multirow{3}{*}{ Philippines } & Labour force & 83 & 91 & 86 & 91 & 87 & 90 \\
\hline & Empl. rate & 68 & 87 & 73 & 71 & 72 & 71 & & Empl. rate & 83 & 88 & 85 & 89 & 81 & 86 \\
\hline & Unempl. rate & 12 & $\mathrm{o}$ & 9 & 9 & 14 & 11 & & Unempl. rate & $\mathrm{o}$ & 3 & 1 & 2 & 7 & 4 \\
\hline \multirow{3}{*}{ Ukraine } & Labour force & 77 & 79 & 77 & 82 & 79 & 81 & \multirow{3}{*}{ Morocco } & Labour force & 43 & 87 & 69 & 40 & 82 & 64 \\
\hline & Empl. rate & 70 & 78 & 72 & 77 & 74 & 76 & & Empl. rate & 35 & 80 & 62 & 26 & 74 & 53 \\
\hline & Unempl. rate & 8 & 2 & 7 & 6 & 6 & 6 & & Unempl. rate & 19 & 8 & 11 & 36 & 10 & 17 \\
\hline \multirow{3}{*}{$\begin{array}{c}\text { Total } \\
\text { immigrants }\end{array}$} & Labour force & 60 & 86 & 72 & 59 & 85 & 71 & \multirow{3}{*}{ Italians } & Labour force & 52 & 74 & 63 & 51 & 72 & 61 \\
\hline & Empl. rate & 52 & 80 & 66 & 51 & 78 & 64 & & Empl. rate & 47 & 70 & 59 & 46 & 67 & 57 \\
\hline & Unempl. rate & 13 & 6 & 9 & 14 & 9 & 11 & & Unempl. rate & 8 & 5 & 7 & 8 & 7 & 8 \\
\hline
\end{tabular}

Source: Own elaborations based on Istat LFS, 2008 and 2011, second quarter

Notes: in 2008 n. $^{\circ}$ of observations is: Belarus 5 ( 5 women), Moldova 96 (72 women), Ukraine 166 (136 women), Romania 669 (364 women), Philippines 148 (83 women), Morocco 385 (175 women), total immigrants 4,253 (2,272 women), Italians 102,353 (51,998 women). In 2011, n. ${ }^{\circ}$ of observations is: Belarus 16 ( 13 female), Moldova 265 (174 women), Ukraine 410 ( 327 women), Romania 1,808 (1,022 women), Philippine 185 (111 women), Morocco 847 (384 women), total immigrants 8,309 (4,488 women), Italy 91,401 (46,741 women).

As pointed out in the last report from Caritas/Migrantes (2011), such gender asymmetry in favour of female workers is a consequence of the sectorial distribution of immigrants according to gender: women, and in particular women from EaP countries and the Philippines, are mainly employed in the home-care and health-care sectors which is protected from international competition and which does not have declining demand ${ }^{21}$.

The distinction between the self-employed and employees shows that selfemployment is not very common among EaP workers. Self-employment is more frequent among Italians (24 per cent) than among foreign nationals (12 per cent) and amongst male (native men 29 per cent) than among female workers (17 per cent native female). It is also more widespread among foreign nationals from Senegal, Morocco and Romania who specialise in the construction and trade sectors. Given the gender composition of the EaP communities, self-employment is not relevant (4 per cent) even if among Moldovan and Ukrainian men it reaches 11 per cent. The OECD report (2012) emphasises that "selfemployment may either be a survival strategy for those who cannot find any other means

${ }^{21}$ See Pastore and Villosio (2011). 
of earning an income or an entrepreneurship strategy which marries the desire to be one's own boss"22. There are examples which go in both directions: in the construction sector there are case of self employed entrepreneurs, more frequently among the older communities and Romanians; in the trade sector by Senegalese and Moroccans. But there are also examples of forced autonomous work which implies a greater uncertainty in income. The type of job specialisation of these communities, however, reduces the chance or the risk for self-employment.

Tab. 3.2 - Employees versus self-employed, by gender, 2011.

Share of working age population (15-64)

\begin{tabular}{|c|c|c|c|c|c|c|c|}
\hline & & Employees & $\begin{array}{c}\text { Self- } \\
\text { employed }\end{array}$ & & & Employees & $\begin{array}{c}\text { Self- } \\
\text { employed }\end{array}$ \\
\hline \multirow{3}{*}{ Belarus } & Female & 82 & 18 & \multirow{3}{*}{ Romania } & Female & 95 & 4 \\
\hline & Male & 100 & o & & Male & 87 & 16 \\
\hline & Total & 86 & 14 & & Total & 90 & 9 \\
\hline \multirow{3}{*}{ Moldova } & Female & 96 & o & \multirow{3}{*}{ Philippines } & Female & 99 & 1 \\
\hline & Male & 87 & 11 & & Male & 95 & 5 \\
\hline & Total & 92 & 4 & & Total & 97 & 3 \\
\hline \multirow{3}{*}{ Ukraine } & Female & 96 & 3 & \multirow{3}{*}{ Morocco } & Female & 95 & 4 \\
\hline & Male & 88 & 12 & & Male & 76 & 23 \\
\hline & Total & 94 & 5 & & Total & 80 & 19 \\
\hline \multirow{3}{*}{$\begin{array}{c}\text { Total } \\
\text { immigrants }\end{array}$} & Female & 91 & 8 & \multirow{3}{*}{ Italians } & Female & 81 & 17 \\
\hline & Male & 83 & 16 & & Male & 70 & 29 \\
\hline & Total & 86 & 12 & & Total & 74 & 24 \\
\hline
\end{tabular}

Source: Own elaborations based on Istat LFS, 2011, second quarter

Notes: . $^{\circ}$ of observation is: Belarus 10 (8 women), Moldova 183 (121 women), Ukraine 308 (248 women), Romania 1,206 (588 women), Philippines 150 (96 women), Morocco 420 (92 women), total immigrants 5,065 (2,183 women), Italy 49,924 (20,918 women).

The total doesn't sum to 100 because some kind of atypical contracts are not counted as employees, and they are not presented in the table.

\subsection{Sectors}

The employment of male Italians is distributed across three main sectors: manufacturing, trade and construction and total migrants follow a similar pattern even if with different percentages, namely the construction sector is much more important for migrants. EaP male migrants follow the same distribution even if they are to be found more in the manufacturing and construction sectors.

Female workers show a very different pattern of employment. Native women are mainly employed in education, health and social work, trade and manufacturing, while female migrants are concentrated in the social and personal services (50 per cent), hotels and restaurants (12 per cent), education health and social work (10 per cent) and manufacturing (9 per cent). Female EaP migrants are especially concentrated in social and personal services (71 per cent, 66 per cent), with a smaller presence in hotel and restaurants (9 per cent) and support services activities (6-10 per cent).

${ }^{22}$ See OECD (2012). 
Tab. 3.3 - Sectors of employment for EaP countries, with some major reference migration countries, by gender, 2011. Share of working age population (15-64)

\begin{tabular}{|c|c|c|c|c|c|c|c|c|c|c|c|c|c|}
\hline Orig in & & Agricult. & Manufact. & Construct. & Trade & $\begin{array}{l}\text { Hotels } \\
\text { and } \\
\text { restaur. }\end{array}$ & Transport & $\begin{array}{c}\text { Inform. } \\
\text { and } \\
\text { communic. }\end{array}$ & $\begin{array}{l}\text { Business } \\
\text { activities }\end{array}$ & $\begin{array}{l}\text { Support } \\
\text { s ervice } \\
\text { activities }\end{array}$ & $\begin{array}{c}\text { Public } \\
\text { sercives }\end{array}$ & $\begin{array}{l}\text { Educ., } \\
\text { health } \\
\text { and } \\
\text { social } \\
\text { work }\end{array}$ & $\begin{array}{l}\text { Other } \\
\text { social } \\
\text { and } \\
\text { pers onal } \\
\text { services }\end{array}$ \\
\hline \multirow{3}{*}{ Belarus } & female & 0.0 & 0.0 & 0.0 & 0.0 & 0.0 & 0.0 & 0.0 & 0.0 & 24.0 & 0.0 & 0.0 & 76.0 \\
\hline & male & 0.0 & 0.0 & 0.0 & 55.8 & 0.0 & 0.0 & 0.0 & 0.0 & 44.2 & 0.0 & 0.0 & 0.0 \\
\hline & total & 0.0 & 0.0 & 0.0 & 12.1 & 0.0 & 0.0 & 0.0 & 0.0 & 28.4 & 0.0 & 0.0 & 59.4 \\
\hline \multirow{3}{*}{ Moldova } & female & 0.0 & 4.1 & 0.5 & 5.9 & 8.9 & 0.5 & 0.0 & 0.2 & 9.6 & 0.0 & 4.1 & 66.2 \\
\hline & male & 5.5 & 29.0 & 32.3 & 4.3 & 5.3 & 10.4 & 4.3 & 0.0 & 1.4 & 0.0 & 1.9 & 5.7 \\
\hline & total & 2.0 & 13.0 & 11.9 & 5.3 & 7.6 & 4.1 & 1.6 & 0.1 & 6.6 & 0.0 & 3.3 & 44.5 \\
\hline \multirow{3}{*}{ Ukraine } & female & 1.6 & 3.7 & 0.0 & 1.5 & 8.7 & 0.4 & 0.0 & 0.0 & 5.6 & 0.0 & 7.2 & 71.3 \\
\hline & male & 3.4 & 22.0 & 28.2 & 11.6 & 10.4 & 9.5 & 0.0 & 0.0 & 3.3 & 0.0 & 0.0 & 11.7 \\
\hline & total & 2.0 & 7.5 & 5.9 & 3.6 & 9.1 & 2.3 & 0.0 & 0.0 & 5.2 & 0.0 & 5.7 & 58.8 \\
\hline \multirow{3}{*}{ Romania } & female & 3.6 & 9.4 & 0.5 & 3.5 & 13.7 & 0.8 & 0.5 & 0.2 & 5.0 & 0.1 & 10.2 & 52.4 \\
\hline & male & 7.1 & 18.4 & 45.6 & 7.8 & 3.9 & 9.5 & 0.0 & 0.0 & 3.0 & 0.2 & 1.1 & 3.5 \\
\hline & total & 5.5 & 14.3 & 24.8 & 5.8 & 8.4 & 5.5 & 0.2 & 0.1 & 3.9 & 0.2 & 5.3 & 26.0 \\
\hline \multirow{3}{*}{ Philippin. } & female & 0.0 & 0.7 & 0.0 & 0.0 & 6.9 & 3.2 & 0.0 & 0.0 & 5.7 & 0.0 & 0.3 & 83.3 \\
\hline & male & 0.0 & 14.5 & 0.0 & 8.0 & 8.8 & 5.3 & 0.0 & 0.0 & 17.1 & 0.0 & 0.0 & 46.4 \\
\hline & total & 0.0 & 5.9 & 0.0 & 3.0 & 7.6 & 4.0 & 0.0 & 0.0 & 10.0 & 0.0 & 0.2 & 69.4 \\
\hline \multirow{3}{*}{ Morocco } & female & 2.5 & 13.8 & 0.0 & 4.8 & 18.0 & 0.0 & 0.0 & 0.0 & 22.1 & 0.0 & 7.0 & 31.8 \\
\hline & male & 5.2 & 33.8 & 18.2 & 23.8 & 5.2 & 6.6 & 0.5 & 0.2 & 3.8 & 0.1 & 0.2 & 2.3 \\
\hline & total & 4.7 & 29.5 & 14.3 & 19.7 & 8.0 & 5.2 & 0.4 & 0.2 & 7.7 & 0.1 & 1.7 & 8.7 \\
\hline \multirow{3}{*}{$\begin{array}{c}\text { Total } \\
\text { immigrants }\end{array}$} & female & 2.4 & 9.0 & 0.4 & 5.8 & 11.9 & 1.1 & 0.5 & 0.3 & 8.9 & 0.4 & 9.6 & 49.6 \\
\hline & male & 6.0 & 27.9 & 27.1 & 12.0 & 6.8 & 7.1 & 0.7 & 0.2 & 4.8 & 0.1 & 1.6 & 5.9 \\
\hline & total & 4.5 & 20.0 & 15.9 & 9.4 & 8.9 & 4.6 & 0.6 & 0.2 & 6.5 & 0.2 & 5.0 & 24.3 \\
\hline \multirow{3}{*}{ Italian } & female & 2.5 & 13.2 & 1.6 & 14.5 & 6.5 & 2.4 & 2.1 & 3.3 & 13.1 & 5.9 & 27.1 & 7.9 \\
\hline & male & 3.9 & 25.2 & 11.6 & 14.8 & 4.3 & 6.4 & 3.0 & 2.8 & 9.6 & 7.6 & 7.2 & 3.6 \\
\hline & total & 3.4 & 20.3 & 7.5 & 14.7 & 5.2 & 4.7 & 2.7 & 3.0 & 11.0 & 6.9 & 15.3 & 5.3 \\
\hline
\end{tabular}

Source: Own elaborations based on Istat LFS, 2011, second quarter.

Notes: Agriculture includes hunting and forestry; Business activities include financial, insurance, real estate activities. Support services activities include Professional, scientific and technical activities, administrative and support service activities; Public services includes Public administration and defence, compulsory social security. N. observation Belarus 10, Moldova 183, Ukraine 308, Romania 1,206, Philippine 150, Morocco 420, Total immigrants 5,065, Italians 49,924.

The overrepresentation of immigrants in some jobs is termed the "ethnicisation" of the job market (ISMU, 2010). It can produce a symbolic barrier for the entrance of natives in the same sectors, which has shrunk only with the crisis as some Italian women are now looking for jobs in the domestic and care sector (ISMU, 2011).

The sector of employment conditions, of course, the occupation skill level and this is especially true for EaP female migrants who are concentrated in the family services sector which does not offer upgrading. The more demanding live-in caregiver jobs are accepted as part of a temporary migration project, or as a phase in the migration project but they only offer the possibility of shifting from live-in caregiver to live-out, which does not present the possibility of income improvement. 


\subsection{Occupation level}

The skill distribution of migrants is strongly gender biased (see tab. 3.4). Native men are not concentrated in elementary occupations ( 7 per cent) and in the very low manual jobs ( 8 per cent), while 24 per cent of all foreign men work in elementary occupations and as lowskilled operators (17 per cent) and the bulk of them are employed as skilled manual workers (42 per cent). Relative to the average of male migrant skill, Ukrainians and Moldovans are more present in skilled positions with respectively 51 per cent and 58 per cent as skilled manual workers. Very few are to be found in higher positions as services and sales workers, or as clerks or technicians, but their importance is larger than in other communities. If we compare the aggregate picture, we can conclude that they hold more qualified occupations relative to the other communities. For the female labour force the picture is even more simple. Italian women are concentrated in clerk or sales assistant positions or higher, while female migrants work mainly in elementary occupation or as service and sale workers. EaP migrants follow this pattern.

Tab. 3.4 - Type of occupations (ISCO), by gender, 2011. Share of working age population (15-64)

\begin{tabular}{|c|c|c|c|c|c|c|c|c|c|}
\hline & & \multicolumn{2}{|c|}{ Highly skilled } & \multirow{2}{*}{$\begin{array}{c}\text { Skilled } \\
\text { Technicians }\end{array}$} & \multicolumn{4}{|c|}{ Low skilled } & \multirow{2}{*}{$\begin{array}{l}\text { Unskilled } \\
\text { Elementary } \\
\text { occupation }\end{array}$} \\
\hline & & $\begin{array}{l}\text { Legislators, } \\
\text { magagers }\end{array}$ & Professionals & & Clerks & $\begin{array}{l}\text { Service } \\
\text { and sale } \\
\text { workers }\end{array}$ & $\begin{array}{l}\text { Skilled } \\
\text { workers }\end{array}$ & Operators & \\
\hline \multirow{3}{*}{ Belarus } & female & 0.0 & 0.0 & 0.0 & 0.0 & 32.1 & 33.2 & 0.0 & $34 \cdot 7$ \\
\hline & male & 0.0 & 0.0 & 0.0 & 0.0 & 0.0 & 55.8 & 0.0 & 44.2 \\
\hline & total & 0.0 & 0.0 & 0.0 & 0.0 & 25.1 & 38.1 & 0.0 & 36.8 \\
\hline \multirow{3}{*}{ Moldova } & female & 0.0 & 0.0 & 0.3 & 1.9 & 32.0 & 7.0 & 3.1 & 55.8 \\
\hline & male & 2.0 & 0.0 & $3 \cdot 7$ & $3 \cdot 7$ & $5 \cdot 7$ & 58.3 & 12.3 & $14 \cdot 3$ \\
\hline & total & 0.7 & 0.0 & 1.5 & 2.6 & 22.6 & $\mathbf{2 5 . 3}$ & 6.4 & 40.9 \\
\hline \multirow{3}{*}{ Ukraine } & female & 0.4 & 1.3 & 1.4 & 0.3 & 49.9 & $5 \cdot 3$ & 1.8 & 39.6 \\
\hline & male & 0.0 & 0.0 & 2.4 & 0.0 & 9.1 & 51.1 & 16.7 & 20.8 \\
\hline & total & 0.3 & 1.1 & 1.6 & 0.3 & 41.3 & 14.9 & 4.9 & $35 \cdot 7$ \\
\hline \multirow{3}{*}{ Romania } & female & 0.2 & 0.6 & 5.6 & 2.0 & 35.9 & 6.3 & 5.1 & 44.5 \\
\hline & male & 0.0 & 0.3 & 1.4 & 0.0 & 6.8 & 55.2 & 17.5 & 18.8 \\
\hline & total & 0.1 & 0.4 & $3 \cdot 3$ & 0.9 & 20.2 & 32.7 & 11.8 & 30.7 \\
\hline \multirow{3}{*}{ Philippines } & female & 0.2 & 0.0 & 0.0 & 0.0 & 10.7 & 0.0 & 0.4 & $\mathbf{8 8 . 7}$ \\
\hline & male & 0.0 & 0.0 & 0.0 & 0.4 & 6.1 & 6.6 & 9.6 & $77 \cdot 3$ \\
\hline & total & 0.1 & 0.0 & 0.0 & 0.1 & 8.9 & 2.5 & 3.9 & 84.4 \\
\hline \multirow{3}{*}{ Morocco } & female & 1.1 & 0.0 & 0.3 & 2.5 & 29.8 & 11.8 & $7 \cdot 7$ & 46.8 \\
\hline & male & 0.5 & 0.5 & 1.8 & 0.7 & 8.5 & 37.5 & 17.0 & 33.6 \\
\hline & total & 0.6 & 0.4 & 1.5 & 1.1 & 13.1 & 31.9 & 15.0 & 36.4 \\
\hline \multirow{3}{*}{$\begin{array}{c}\text { Total } \\
\text { immigrants }\end{array}$} & female & 0.5 & 3.0 & 5.1 & 2.7 & 34.5 & 7.0 & 4.2 & 43.2 \\
\hline & male & 0.8 & 1.6 & 2.9 & 1.5 & 10.4 & 42.1 & 16.7 & 24.2 \\
\hline & total & 0.6 & 2.2 & 3.8 & 2.0 & 20.5 & $27 \cdot 3$ & 11.4 & 32.2 \\
\hline \multirow{3}{*}{ Italian } & female & 1.9 & 18.9 & 19.9 & 19.9 & 22.4 & $5 \cdot 3$ & $3 \cdot 3$ & 8.4 \\
\hline & male & 4.2 & 10.3 & 19.6 & 7.8 & 13.4 & 25.1 & 11.0 & 6.9 \\
\hline & total & $3 \cdot 3$ & 13.8 & 19.7 & 12.7 & 17.1 & 17.0 & 7.9 & $7 \cdot 5$ \\
\hline
\end{tabular}

Source: Own elaboration based on Istat LFS, 2011, second quarter

Notes: Skilled workers include skilled agricultural, forestry and fishery workers, craft and related trade workers; Operators include plant and machine operators and assemblers. N. observation Belarus 10, Moldova 183, Ukraine 308, Romania 1,206, Philippine 150, Morocco 420, Total immigrants 5,065, Italians 49,924.

For Italian the percentage doesn't sum to 100 per cent because army is not presented in the table. 
What emerges from the occupation classification (ISCO) is that Italy is a country that holds a limited number of highly-skilled occupations. If we sum up legislators and managers, professionals and technicians we end up with less than 37 per cent of Italian employment, 7 per cent of the foreign employment, and an even smaller number for EaP migrants. The first impression is that the Italian labour market offers only unskilled jobs to foreign nationals whatever their level of education might be.

\subsection{Education}

To measure education level we use the ISCED classification. This measure allows us to distinguish the level of education in terms of the years invested in education and any degree obtained. Its use in a comparative context is always questionable because the quality of education is not taken into account and this undermines comparison even within the same country. However, it does provides a very rough measure of the potential human capital embodied in the migrant.

Among working age population (15-64), Italians are more educated in comparison to all migrants 23 . However, immigrants from EaP countries, especially women are even more educated than Italians. As shown in Table 3.6, the share of women with a tertiary level of education is 26 per cent from Ukraine ( 6 per cent of men), and 14 per cent from Moldova (17 per cent of men) and 21 per cent of women from Belarus. These percentages are higher than in other immigrants groups and among the most important foreign communities only 5 per cent of Romanians, 10 per cent of Filipinos and 4 per cent of Moroccans completed the university degree, regardless of gender. However, even if better educated than Italians, most foreign people do not ask recognition of their foreign qualifications because these are not considered relevant for the job in which they are employed. ${ }^{24}$ A mere 6 per cent of Ukrainians asked for recognition, admittedly a higher percentage with respect to other immigrants (see Table 3.5).

These figures are consistent with additional sources presented by ISMU and Caritas.

Tab. 3.5 - Recognition of foreign qualification, EaP countries and total immigrants, 2008. Share of working age population (15-64)

\begin{tabular}{|l|r|r|r|r|r|r|r|}
\hline & Yes & & \multicolumn{2}{l}{$\begin{array}{l}\text { Yes (practice } \\
\text { in progress) }\end{array}$} & $\begin{array}{l}\text { No (not necesary } \\
\text { for the job done) }\end{array}$ & $\begin{array}{l}\text { No (financial } \\
\text { reasons) }\end{array}$ & $\begin{array}{l}\text { No (other } \\
\text { reasons) }\end{array}$ \\
\hline Belarus & 0.0 & 0.0 & 43.6 & 50.1 & 6.3 & 0.0 \\
\hline Moldova & 0.9 & 1.2 & $\mathbf{5 4 . 3}$ & 11.2 & 31.2 & 1.2 \\
\hline Ukraine & $\mathbf{5 . 7}$ & 2.5 & $\mathbf{6 4 . 7}$ & 10.9 & 12.1 & 4.1 \\
\hline Romania & 3.6 & 1.8 & 75.2 & 9.9 & 8.9 & 0.8 \\
\hline Philippines & 0.6 & 0.1 & 84.0 & 11.9 & 2.6 & 0.9 \\
\hline Morocco & 1.7 & 1.0 & 76.2 & 12.2 & 8.9 & 0.0 \\
\hline Total immigrants & 3.9 & 1.4 & 72.6 & 10.5 & 10.1 & 1.5 \\
\hline
\end{tabular}

Source: Own elaborations based on Istat LFS, 2008, second quarter

\footnotetext{
23 If the comparison is made using the employed population instead of working age population, the share of highly educated natives and foreigners increases keeping the same ranking.

24 Data available only for 2008, when the Labour Force Survey contained an ad hoc module for foreign people.
} 
Tab. 3.6 - Education level (ISCED 97) EaP countries and reference countries, by gender, 2011. Share of working age population (15-64)

\begin{tabular}{|c|c|c|c|c|c|c|c|}
\hline & & $\begin{array}{c}\text { ISCED o } \\
\text { Pre- } \\
\text { primary } \\
\text { education }\end{array}$ & $\begin{array}{c}\text { ISCED } 1 \\
\text { Primary } \\
\text { education }\end{array}$ & $\begin{array}{c}\text { ISCED } 2 \\
\text { Lower } \\
\text { secondary } \\
\text { education }\end{array}$ & $\begin{array}{c}\text { ISCED } 3 \\
\text { Upper } \\
\text { secondary } \\
\text { education }\end{array}$ & $\begin{array}{c}\text { ISCED } 5 \\
\text { Tertiary } \\
\text { education }\end{array}$ & $\begin{array}{l}\text { ISCED } 6 \\
\text { 2nd level } \\
\text { of tertiary } \\
\text { education } \\
\text { (PhD) }\end{array}$ \\
\hline \multirow{3}{*}{ Belarus } & female & 10.5 & 11.8 & 6.0 & 50.6 & 21.1 & 0.0 \\
\hline & male & 0.0 & 0.0 & 61.8 & 38.2 & 0.0 & 0.0 \\
\hline & total & 8.6 & 9.6 & 16.2 & 48.3 & $17 \cdot 3$ & 0.0 \\
\hline \multirow{3}{*}{ Moldova } & female & 3.6 & 0.4 & 37.7 & 43.8 & 14.4 & 0.2 \\
\hline & male & 0.0 & 0.0 & 38.1 & 45.2 & 16.7 & 0.0 \\
\hline & total & 2.3 & 0.2 & 37.9 & $44 \cdot 3$ & 15.2 & 0.1 \\
\hline \multirow{3}{*}{ Ukraine } & female & 3.7 & 1.2 & 23.8 & $45 \cdot 3$ & 25.6 & 0.5 \\
\hline & male & $3 \cdot 7$ & $3 \cdot 3$ & 35.8 & 50.8 & 6.1 & 0.4 \\
\hline & total & 3.7 & 1.6 & 26.4 & 46.5 & 21.4 & 0.5 \\
\hline \multirow{3}{*}{ Romania } & female & 2.7 & 2.9 & $25 \cdot 3$ & 60.9 & 8.3 & 0.0 \\
\hline & male & 3.0 & 3.0 & 30.0 & 61.8 & 2.2 & 0.0 \\
\hline & total & 2.8 & 2.9 & 27.5 & 61.3 & $5 \cdot 5$ & 0.0 \\
\hline \multirow{3}{*}{ Philippines } & female & $3 \cdot 3$ & 3.8 & 30.5 & 53.8 & 8.8 & 0.0 \\
\hline & male & 0.8 & 2.4 & 44.8 & 41.1 & 10.9 & 0.0 \\
\hline & total & 2.3 & 3.2 & 36.2 & 48.7 & 9.6 & 0.0 \\
\hline \multirow{3}{*}{ Morocco } & female & 18.0 & 9.6 & 42.0 & 25.8 & $4 \cdot 7$ & 0.0 \\
\hline & male & 12.4 & 15.2 & 41.7 & 26.6 & 4.1 & 0.0 \\
\hline & total & 14.8 & 12.7 & 41.9 & 26.3 & 4.4 & 0.0 \\
\hline \multirow{3}{*}{$\begin{array}{c}\text { Total } \\
\text { immigrants }\end{array}$} & female & 5.9 & 5.1 & 34.4 & 42.8 & 11.7 & 0.1 \\
\hline & male & 6.0 & 6.1 & 40.6 & 40.6 & 6.6 & 0.2 \\
\hline & total & 5.9 & 5.6 & 37.4 & 41.8 & 9.3 & 0.1 \\
\hline \multirow{3}{*}{ Italian } & female & 1.2 & 9.8 & 33.6 & 40.5 & 14.7 & 0.3 \\
\hline & male & 0.8 & 6.7 & 39.3 & 41.1 & 11.8 & 0.3 \\
\hline & total & 1.0 & 8.2 & 36.5 & 40.8 & 13.2 & 0.3 \\
\hline
\end{tabular}

Source: Own elaborations based on Istat LFS, 2011, second quarter

Notes: Istat classification is more detailed. We elaborate the education levels in the ISCED groups following Istat (2005). See the Annex, Table A.2, for the correspondence between Istat classification and ISCED. N. observation Belarus 16, Moldova 265, Ukraine 410, Romania 1,808, Philippine 185, Morocco 847, Total immigrants 8,309, Italians 91,401.

\subsection{Education and skill mismatch}

The mismatch between occupation type and the education of immigrants from EaP countries leads to the well-known phenomenon of the over-qualification of migrants employed in the Italian labour market, which is, however, a problem for native workers too. According to Dell'Arringa and Pagani (2011) the share of over-educated migrants amounts to 95 per cent. In the case of immigrants from EaP countries, who are on average better educated than others, the mismatch is even stronger. Indeed, we notice in Table 3.7 that, regardless of the level of education, women are employed in unskilled and low-skilled profession, and men are mainly employed in low-skilled professions (see Table A.3, in the Annex, for immigrants from Belarus).

From the ISMU report (2011), in Lombardy immigrants from Ukraine and Moldova work in low-skilled profession, especially as caregivers, regardless of their level of education. According to Fullin and Reyneri (2011), even the employment of male immigrants in lowskilled occupation, instead of unskilled jobs, does not mean an improvement in status, 
because they are mainly employed in small firms, with low wages, poor social protection and low social recognition.

As Dell'Arringa e Pagani (2011) pointed out, immigrants more easily accept poor working conditions which keep them down at the bottom of the occupational ladder, producing, in the process, brain-waste. While several features of the Italian labour market and the match between supply and demand can explain the concentration of immigrants in low-quality occupations, it is important to note that the majority of women from EaP countries came to Italy aware that they would work as live-in carers of elderly people. However, most of them consider this job as an initial phase of their migration project and do not intend to carry on working in this way (Pasquinelli and Rusmini, 2008).

A brief look at Table 3.7 shows clearly that the diagonal of the table is empty, and that all the migrants, whatever their level of education might be, are all doing same skill jobs. The mismatch between tertiary education and job skill level is stronger among EaP migrants, both men and women.

Tab. 3.7 - Skill mismatch by gender (percentage), Moldova and Ukraine, and total immigrants, 2011. Share of working age population (15-64)

\begin{tabular}{|c|c|c|c|c|c|c|c|c|c|c|c|c|c|c|c|c|}
\hline & \multirow[b]{2}{*}{ Professions } & \multicolumn{4}{|c|}{ Education } & & \multicolumn{4}{|c|}{ Education } & & \multicolumn{4}{|c|}{ Education } & \multirow[b]{2}{*}{ Tot } \\
\hline & & $\begin{array}{c}\text { Primary } \\
\text { and } \\
\text { below }\end{array}$ & $\begin{array}{c}\text { Lower } \\
\text { second. }\end{array}$ & $\begin{array}{l}\text { Upper } \\
\text { second. }\end{array}$ & Tertiary & Tot & $\begin{array}{l}\text { Primary } \\
\text { and } \\
\text { below }\end{array}$ & $\begin{array}{l}\text { Lower } \\
\text { second. }\end{array}$ & $\begin{array}{l}\text { Upper } \\
\text { second. }\end{array}$ & Tertiary & Tot & $\begin{array}{c}\text { Primary } \\
\text { and } \\
\text { below }\end{array}$ & $\begin{array}{l}\text { Lower } \\
\text { second. }\end{array}$ & $\begin{array}{l}\text { Upper } \\
\text { second. }\end{array}$ & Tertiary & \\
\hline & & \multicolumn{4}{|c|}{ Moldova } & & \multicolumn{5}{|c|}{ Ukraine } & \multicolumn{4}{|c|}{ Total immigrants } & \\
\hline \multirow{5}{*}{ 过 } & Unskilled & 0 & 59 & 50 & 74 & 56 & 27 & 35 & 40 & 45 & 40 & 51 & 49 & 43 & 29 & 43 \\
\hline & Low skilled & 100 & 41 & $\mathbf{5 0}$ & 24 & 44 & 73 & 64 & 59 & 48 & 57 & 47 & 50 & 51 & 36 & 48 \\
\hline & Skilled & 0 & 0 & 0 & 1 & 0 & 0 & 0 & 1 & 3 & 1 & 0 & 1 & 4 & 20 & 5 \\
\hline & Highly skill. & 0 & 0 & 0 & 0 & 0 & 0 & 2 & 0 & 4 & 2 & 1 & 1 & 2 & 16 & 3 \\
\hline & Total & 100 & 100 & 100 & 100 & 100 & 100 & 100 & 100 & 100 & 100 & 100 & 100 & 100 & 100 & 100 \\
\hline \multirow{5}{*}{$\frac{0}{\frac{\pi}{3}}$} & Unskilled & 0 & 27 & 11 & 8 & 14 & 64 & 19 & 21 & 0 & 21 & 42 & 26 & 20 & 15 & 24 \\
\hline & Low skilled & 0 & 73 & 84 & 79 & 80 & 36 & 81 & 76 & 94 & 77 & 57 & 74 & 76 & 46 & 71 \\
\hline & Skilled & 0 & 0 & 2 & 12 & 4 & 0 & 0 & 3 & 6 & 2 & 1 & 1 & 3 & 16 & 3 \\
\hline & Highly skill. & 0 & 0 & 4 & 0 & 2 & 0 & 0 & 0 & 0 & 0 & 0 & 0 & 1 & 23 & 2 \\
\hline & Total & 0 & 100 & 100 & 100 & 100 & 100 & 100 & 100 & 100 & 100 & 100 & 100 & 100 & 100 & 100 \\
\hline \multirow{5}{*}{ है } & Unskilled & 0 & 49 & 35 & 48 & 41 & 37 & 31 & 35 & 41 & 36 & 45 & 34 & 30 & 23 & 32 \\
\hline & Low skilled & 100 & 51 & 63 & 46 & 57 & 63 & 68 & 63 & 51 & 61 & 54 & 65 & 65 & 40 & 61 \\
\hline & Skilled & 0 & 0 & 1 & 6 & 1 & 0 & 0 & 2 & 3 & 2 & 1 & 1 & 3 & 18 & 4 \\
\hline & Highly skill. & 0 & 0 & 2 & 0 & 1 & 0 & 1 & 0 & 4 & 1 & 0 & 0 & 1 & 19 & 3 \\
\hline & Total & 100 & 100 & 100 & 100 & 100 & 100 & 100 & 100 & 100 & 100 & 100 & 100 & 100 & 100 & 100 \\
\hline
\end{tabular}

Source: Own elaborations based on Istat LFS, 2011, second quarter

Notes: n. ${ }^{\circ}$ of observations: Moldova 183 (121 women), Ukraine 308 (248 women),total immigrants 5,065 (women 2,183). For the skilled mismatch by gender for immigrants from Belarus see Table A.3, in the Annex.

The employment sector and the level of occupation means lower wages than those enjoyed by Italians, with higher gender wage gaps (34 per cent for Moldovans, 25 per cent for Ukrainians), in line with the gender wage gap of all immigrants. The average wage for women and men is respectively 793 Euros and 1.053 for Ukrainians, and 753 Euros and 1,137 Euros for Moldovans, as for Romanians (see tab. 3.8). 
Tab. 3.8 - Average monthly wages (in $€$ ) for working age (15-64) immigrants from EaP countries and some reference groups, by gender, 2011

\begin{tabular}{|c|c|c|c|c|c|c|c|}
\hline & \multicolumn{2}{|c|}{ Women } & \multicolumn{2}{|c|}{ Men } & \multicolumn{2}{|c|}{ Total } & \multirow{2}{*}{$\begin{array}{l}\text { Unadjusted } \\
\text { gender gap }\end{array}$} \\
\hline & Obs. & Mean & Obs. & Mean & Obs. & Mean & \\
\hline Azerbaijan & 2 & 992 & & & 2 & 992 & \\
\hline Belarus & 7 & 727 & 2 & 1,288 & 9 & 869 & 43.60 \\
\hline Georgia & 1 & 400 & & & 1 & 400 & \\
\hline Moldova & 116 & 754 & 55 & 1,137 & 171 & 883 & 33.71 \\
\hline Ukraine & 238 & 793 & 54 & 1,053 & 292 & 844 & 24.70 \\
\hline Romania & 552 & 763 & 541 & 1,140 & 1,093 & 959 & 33.07 \\
\hline Russia & 26 & 852 & 5 & 968 & 31 & 877 & 11.95 \\
\hline Philippines & 93 & 757 & 52 & 842 & 145 & 789 & 10.05 \\
\hline Morocco & 86 & 754 & 251 & 1,112 & 336 & 1,020 & 32.24 \\
\hline Total immigrants & 1,970 & 809 & 2,429 & 1,131 & 4,399 & 989 & 28.51 \\
\hline Italian & 16,853 & 1,143 & 20,014 & 1,410 & 36,867 & 1,291 & 18.94 \\
\hline
\end{tabular}

Source: Own elaborations based on Istat LFS, 2011, second quarter

Notes: All income less than $250 €$ is recorded as $250 €$, and all income over $3000 €$ is recorded as $3000 €$. As a consequence, Italian wages (especially for men) are probably lower than in reality.

The gap in female immigrants' wages with respect to males' depends on the different sector in which they are employed. As explained in the next paragraph, the national collective agreement set a minimum wage for domestic workers which is lower than the standard one, and this situation may be even worse among irregular workers (not in the data), estimated to be 50 per cent in the domestic sector.

Nevertheless part of this has to be considered a result of gender wage discrimination between immigrants which remains even after controlling for employment sectors, which, if added to ethnic discrimination, leads to the "double negative-effect"25suffered by female immigrants (Piazzalunga, 2011).

\subsection{Domestic and care labour sector}

Care and domestic work is central to an understanding of contemporary migration to Italy. On the basis of the Istat LFS, Censis (2010) shows that 2.5 million Italian families hire a domestic worker or a caregiver, giving employment to about 1.5 million people. These are for the most part women but also, increasingly, some men ${ }^{26}$. The role of foreign workers is paramount in this sector, and EaP countries retain an increasingly important position compared to other immigrant groups: Moldovans, Ukrainians and Belarusians are the three groups that have multiplied their participation in the sector.

The reason behind such an expansion is rooted in the traditional weakness of welfare in Italy, where families are the main providers of everyday care services to children, elderly, disabled and other needy people. This places Italy as one of the "Mediterranean welfare" countries together with Spain, Greece and Portugal (Esping-Andersen, 1990; Ferrera and Rhodes, 2000). In this scenario the crisis of traditional family models, the rapid ageing of

\footnotetext{
25 For a literature review on double or multiple discrimination, see Ruwanpura (2008).

${ }^{26}$ On the masculinisation of domestic work in Italy see Ambrosini and Beccalli (2009).
} 
society, and other life-style transformations have pushed increasing numbers of households to search for external help for tasks which were accomplished within the family itself in the not too distant past.

\subsubsection{Advantages and disadvantages}

From the labour rights perspective domestic and care workers are regulated by the same national collective agreement. This is far less advantageous than agreements in place for other sectors, with a minimum wage of 850 Euros against the standard 1350 Euros, and reduced support to workers in case of sickness or maternity leave (cfr. Villosio and Bizzotto, 2011; Sarti, 2011). The stigmatisation of this kind of work as unqualified, together with the scarce levels of unionisation, contributes to the depreciation of this job. Workers in this sector often face de-skilling, low remuneration, emotional distress and frequent health problems (Censis, 2010).

Yet, from the point of view of Italian migration policies, care and domestic workers offer advantages in comparison to others. Already in the 2002 regularisation domestic and care workers received special treatment with the extension of the deadline for applications. More recently, in 2009, an amnesty was given expressively to this sector (see Section 1).

Moreover, the annual allocation of quotas for foreign workers always assigns a relatively high number of permits to prospective care and domestic workers. Yet, the applications submitted surpasses the quota: e.g. in the year 2011 the quota was of 30,000 yet there were 60,983 applicants. The quota system, moreover, differentiates on the basis of the nationality of the applicants, setting a different threshold for each country of origin on the basis of bilateral agreements.

\subsubsection{The 2009 regularisation ${ }^{27}$}

With the last regularisation of Ukrainians, who already participated in large numbers in the 2002 regularisation (101,651 applications), emerged to be the most active in the sector, with 37,211 applications. Moldovans followed them with 26,605 applications (against 29,471 in the 2002). Yet, other EaP migrant workers were the novelty here. Although still few, their numbers are on the rise: if data from the 2002 regularisation do not even report their case, now there are 5,332 applications from Georgians, 1,226, from Belarusians, 43 from Armenians and 13 from Azerbaijanis.

\footnotetext{
${ }^{27}$ It is important to point to a certain scepticism amongst experts over the 2009 regularisation and its role in portraying what is really happening in this sector. This regularisation has been accompanied by strong complaints that it is intrinsically discriminatory and a number of court cases have followed its promulgation (see Bascherini and Niccolai, 2010; Nanni, 2010). First assessments also do not exclude the possibility that a number of people, men especially, working irregularly in other sectors, sought to regularise their position by faking employment as domestic workers or care givers.
} 


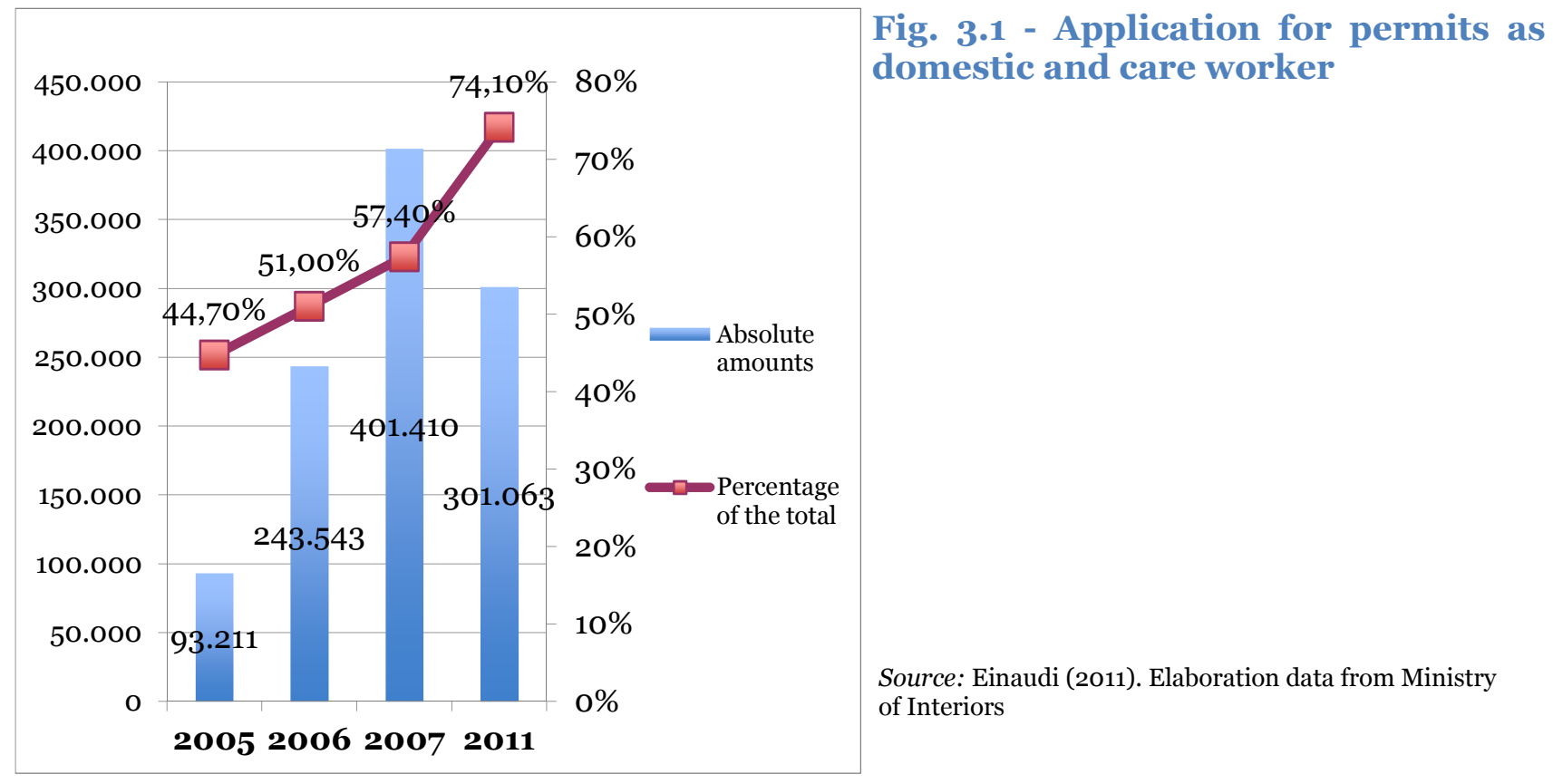

\subsection{Conclusion}

The section provided a comprehensive analysis of labour market outcomes for immigrants from EaP countries. These are strongly influenced by the fact that EaP migration to Italy is dominated by women employed in "social and personal services" (domestic and care work). Their activity rate is higher than that of Italian and other migrants. But it is also higher than their male peers. Moreover, even during the economic crisis their unemployment rate did not increase, given their employment sector. This is one of the main advantages of working in the domestic sector, together with the special quotas in amnesties (2002, 2009) and planned flows.

On the other hand, the family services sector does not allow upgrading. Hence, regardless of their high level of education, women from EaP countries are employed in unskilled and the low-skilled professions, and they experience a wage gap even with respect to men from the same country of origin, in part because of the national collective agreement, which is lower than agreements in place for other sectors. 


\section{Effects in destination and in sending countries}

\subsection{Impact of immigration on the Italian labour market}

\subsubsection{Wage and Employment}

Several studies ${ }^{28}$ find that migrants have a positive effect on the wages of native workers and on the transition from unemployment to employment and vice versa. This effect is nil for the most vulnerable group the young. Both analyses are based upon the use of the social security dataset (Whip) and the Bank of Italy dataset which provide individual data in panel form for the first, and repeated cross sections with retrospective information for the second. In both datasets employment in the industrial and service sector are well reported, while employment in the family services are lacking. Thus in the case of EaP migrants they better represent the role played by male foreign workers in the labour market. The positive effect of migrants on the wages of natives is expected, given the system of industrial relations prevailing in Italy with national negotiations that fix worker compensation. This has limited local flexibility and there are also strong trade unions that protect the internal labour market (i.e. workers already employed).

\subsubsection{Care workers and female employment}

More specifically on the effect of female migrants employed in the family services research by Barone and Mocetti (2010) and Romiti and Rossi (2011) show a strong complementary effect for migrant workers towards native female workers. The first focus on female labour force participation and wage, while the second focus on the decision of carrying on working when family load increases due to parents' ages. Both papers shows how foreign migrants working in the family sectors as care givers for children, old age people and help in the houses favour the labour force participation of highly skilled women who work in other sectors. Yet, no analyse exists on the family sector per se and whether the increase in migrant woman is reducing the wages and the probability of employment for low-skilled native women.

As was noted above this type of job is divided into two quite different sub-types: one foresees cohabitation and has a limited appeal for native Italians and also for more settled migrants, and the other is flexible in the working hours and which also sees participation on the part of Italian women. If, in the first type, cohabitation reduces any possible competition between the two groups, in the second competition exists and wage reduction for this type of employment has been confirmed.

In addition, the recession has extended the supply of native women in more marginal sectors like family services and the large presence of foreign nationals increases the competition ${ }^{29}$.

\footnotetext{
${ }^{28}$ See Gavosto, Venturini and Villosio (1999); Venturini and Villosio (2006);Staffolani and Valentini (2009); Damuri and Pinotti (2010).

29 See ISMU (2011); Pastore and Villosio (2011).
} 


\subsubsection{Irregular labour market}

Family service together with the agriculture and construction sectors are the areas which have most irregular labour employment and in the irregular labour market the competition is stronger because workers are not protected by national negotiation. Venturini (1999) finds evidence of competition in employment between natives and foreign nationals in the informal sectors with, however, no specific detail for the family service sector.

\subsubsection{Competition between internal and international migrants}

The competitive role played by migrants in the Italian labour market is, however, frequently insufficiently captured by the traditional approach. Economists, especially, with their econometric tests, slice the country data by region or sector, and analyse relations inside specific areas. In fact, migrants in Italy are not competitive with the workers looking for jobs in the area where they work. Rather they complement them. Migrants displace workers from the less advantaged regions (in the south) who are ready to move internally (to the north) as Bruecker, Facchin and Venturini (2011) have shown. This creates a double advantage for the workers in the more developed areas (in the north), where the migrants work, because they complement labour and capital, while it produces a double disadvantage for the less developed areas (in the south) where there are potential native migrants who would like, as they had done in the past, to move in search of jobs, but they are now taken by foreign nationals. The presence of available labour in the more developed regions also disincentives the move of capital in the less developed ones and this create the second disadvantage.

\subsection{Migrants and the down turn}

The section above notes the complementary role of the migrants in the Italian labour market, a generalisation that we can extend to EaP workers. It would be interesting to understand if the recession is changing this role and whether it is increasing the competition between these two segments of the labour market.

Since the start of the economic crisis a changing picture has emerged. Native workers concentrated in the manufacturing sector have suffered more from the recession and have lost their jobs at a steeper rate than migrants. Foreign workers, mainly low-skilled foreign workers, were employed in sectors less exposed to international competition like agriculture, construction and family services. In this way they were initially better protected. The aggregate picture suggested that the natives were more at risk of unemployment and poverty. The trend on the employment index is declining for natives, while it was increasing for foreign nationals until 2010. This might create occasional competition between natives and foreign nationals but also between different cohorts of immigrants who resemble natives the more they stay in the destination country.

All the Italian regions experienced an increase in foreign employment and a decrease in native employment. However, in the north where foreign nationals are more similar to 
natives the growth was lower because there was a decline in demand from the industrial sector.

Fig. 4.1 - Employment rate by nationality, 2008-2010 (1st quarter $2008=100$, quarterly data)

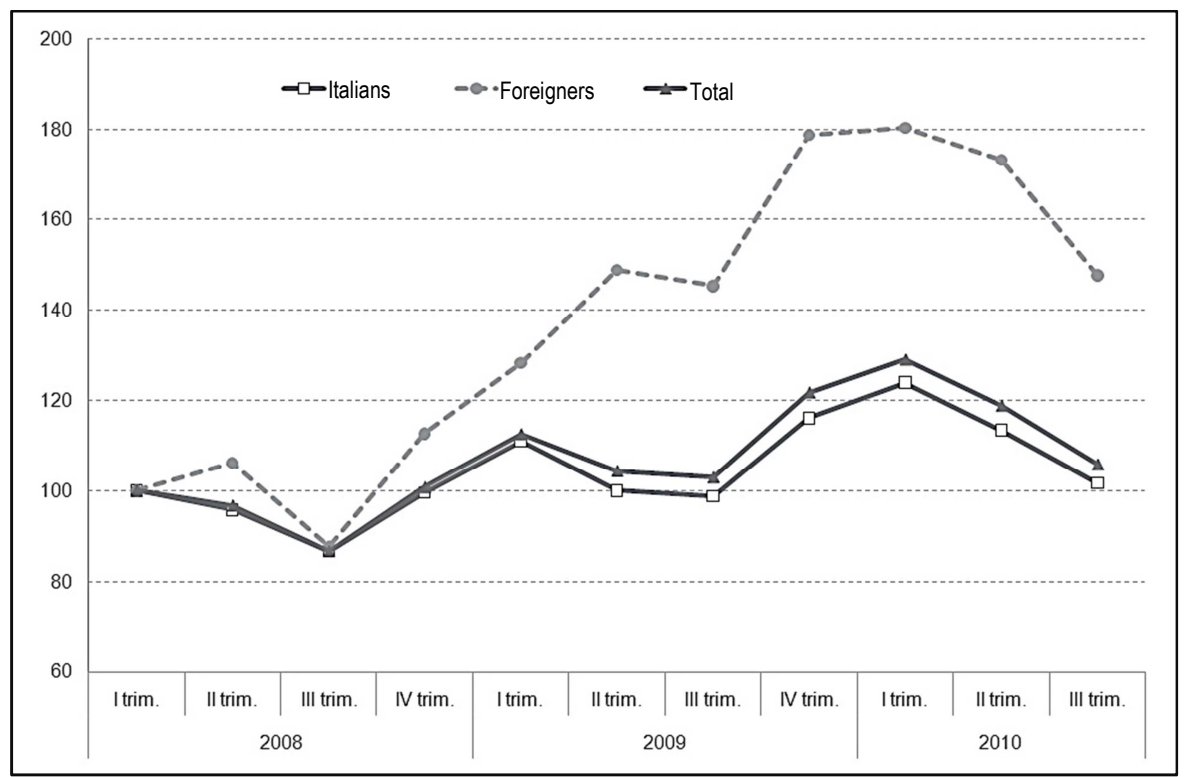

Source: Ministero del lavoro, 2011

Fig. 4.2 - Unemployment rate by nationality, 2008-2010 (1st quarter $2008=100$, quarterly data)

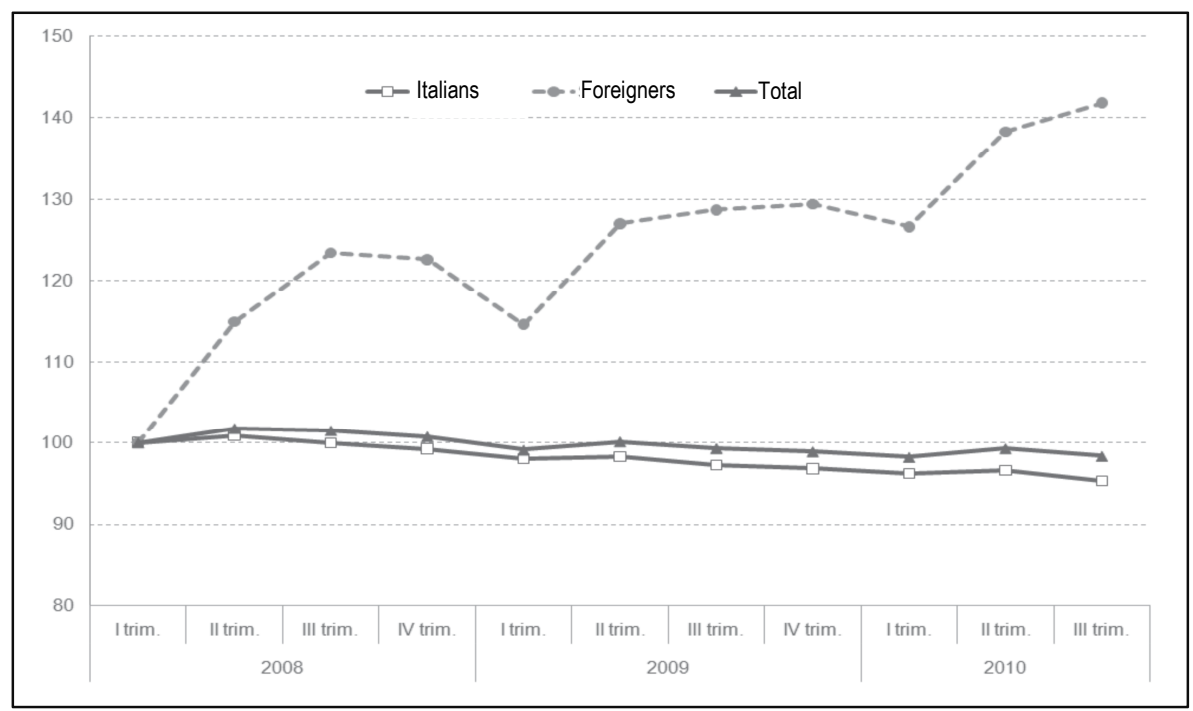

Source: Ministero del lavoro, 2011

rapidly in 2010.

On the one hand, there is still a demand for foreign labour. But, at the same time, more foreign workers are becoming unemployed especially in the north where the unemployment rate of the natives also increased more. Paggiaro (2011) compares the transition from the employment and unemployment of migrants and natives with a score
The ability of migrants to keep their job depends on their low skill position. The white collar workers and the managers are those who suffer a larger relative reduction, but they also represent smaller numbers.

However, even if the number of employed foreign workers increased, the employment rate is decreasing even for foreign people since the end of 2008. The inflow of immigrants, in fact, continued even during the crisis, but finding a job became more difficult, as the increases of the unemployment rate show.

Indeed, if we look at the unemployment rate the picture is not so reassuring. Migrants are suffering an increased unemployment rate, higher than the one of the natives, which increased particularly at the end of 2009, but that also decreased more 
matching model, and if a differential between natives and foreign nationals in unemployment probability exists, when the match is done no statistically differential remains and the result points out to a compositional effect. Migrants are no more or no less likely to be unemployed than Tab. 4.1 - Unemployment rate 2008-10 by natives. nationality and area

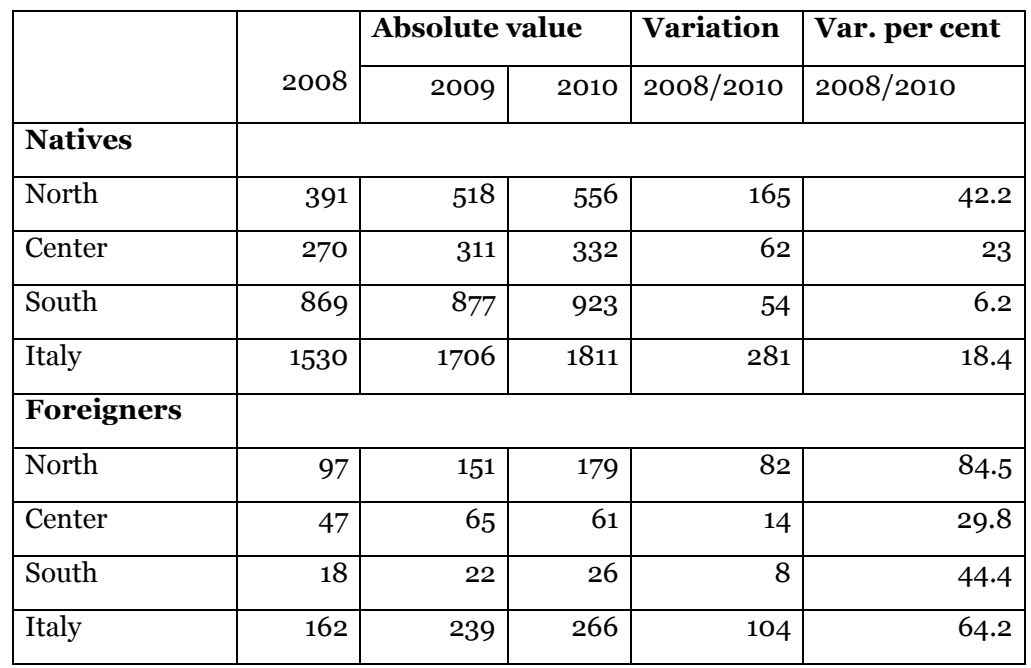

If we look inside the migrants group, however, a gender differential exist: male migrants suffer from increasing unemployment while female migrants are experiencing a reduction in the same because their sector of employment is less exposed to the international economic cycle. Rather it is driven by the endogenous ageing of the domestic population (see Pastore and Villosio, 2011).

\subsection{Welfare, social services and migrant workers}

An important theme of the political debate focuses upon the use done by migrants of the public welfare and social services in destination countries. If migrants are not competitive with the native workers and if, on the contrary, they complement natives, they could still, however, be costly because they use the welfare state more than natives. Much research deals with this issue without any clear conclusions, while very little attention is to the role that migrants and in particular caregivers working in families play in supporting the national welfare system. This section will describe first the results of the empirical research on the use by foreign nationals of welfare programmes, and then their contribution to the welfare services.

This dimensions of care services in Italy tends to be organised locally by provinces and municipalities in accordance with law $328 / 2000$ on social services and policies. Institutions, however, have only modest amounts of care receivers, and what actually happens is that individual families employ caregivers through informal channels or through private agencies.

However, welfare also entails financial support for workers who are sick (or pregnant), workers who are retired or unemployed, together with services related to schools, hospitals, rehabilitation centres, social housing, etc. In Italy these other dimensions of welfare tend to be organised at the state or region level, on the basis of the process of "federalisation" which has been taking place in Italy since 2001. This "side" of welfare sees migrant workers in a more ambiguous position. The representation of migrants as draining resources from state support, becoming "competitors" with Italian working classes, is 
spreading. Those who claim that migrants "bring more than what they take" oppose this view. Data and arguments regarding this debate will be discussed in the last paragraph of this section.

\subsubsection{Access to welfare and social services}

Aggregate research on the use of welfare by foreign nationals shows that migrants on average use the welfare state more than natives because they are more eligible being poor and having larger families.30 When foreign nationals are compared to natives with the same characteristics their use of welfare declines and becomes similar to that of the natives.

The analyse of Tito Boeri in Bruecker (2010) using the EU-SILC dataset shows that migrants in Italy use contributory benefits (pension, unemployment) less than natives because they are younger. However, they use the non-contributory benefits (education, health) more. This result is aggregate thus it is difficult to read and to use it to explain EaP migrants' impact on the welfare system. The same result is pointed out by De Villanova (2009) where a rough comparison between the natives and the Extra-EU25 countries shows a larger use of benefits by natives if the pension benefits are included, but a lower one if they are excluded. The different average age amongst the two groups suggests that the aggregate comparison is not correctly reporting the cost of migrants for the welfare.

More accurate analyses by Pellizzari (2011) which include the welfare provision provided at the regional level by social services confirm a larger average welfare use by migrants relative to natives, which is persistent even when compared to natives with the same characteristics.

None of these studies is, however, broken down by nationality thus it is difficult to extend the aggregate behaviour to specific national groups. It is, however, unlikely that women working as care givers have the possibility of using welfare a lot because they are in general older, not in reproductive age (maternity costs are more expensive) and they rarely have children with them, according to the ISMU regional survey report, thus the cost of kindergarden and school are not relevant, nor the health provision for babies.

On the basis of a 2007 enquiry conducted by Bocconi University (Pellizzari, 2011) migrant households are more likely than Italian ones to have access to social services for lowincome families. This places migrants as potential beneficiaries of state support in the field of health, education or housing, depending on the way this is organised at the local level. More frequently than before, the possibility of creating barriers for the access to rights and services on the basis of nationality is a matter of dispute in several Italian towns.

Nanni and Fucillitti (2011) and Tognetti Bordogna (2011), however, argue that the cost of migrants on the Italian social security system is minimal in comparison to the "resources" they actually bring, through their employment in the home-care sector. This has mainly to do with two orders of reasons. First, the younger composition of the immigrant population

${ }^{30}$ It is important to notice however that the fertility rate of foreign women seem to decrease: from 2.5 children per woman in 2006 to 2.05 in 2009 (cfr. Blangiardo in ISMU, 2011, p. 40). 
in comparison to the Italian population. The migrant population is indeed 70 per cent composed of people younger than 40 years of age. This is particularly relevant if we consider that 60.5 per cent of Italian public expenditure is directed towards the elderly. And, second, migrant workers more rarely fulfil the requirements needed to access social benefits which are based on stable work positions, which migrants seldom have (Nanni and Fucillitti, 2011, p. 54).

In the case of health services, migrants tend to access them less than Italians. We have data from an inquiry published by Istat in 2008 on gynaecological treatments. It emerged that only the 43 per cent of foreign women (against 73 per cent of Italians) had had a mammography screening, and only 53 per cent (against 72 per cent of Italians) had done a pap-test at least once in their lives (Istat, 2008). On the contrary, foreign women are overrepresented amongst those who resort to abortions. Indeed, if one considers all the abortions taking place in Italy in 2003, 26 per cent were for migrant women. And amongst these 50 per cent were Eastern Europeans (Istat, 2006). We thus see that migrants, women especially, seem to turn to the health system only in case of emergency and extreme need, while they seldom undertake screenings and preventative therapies.

\subsubsection{Migrants as "providers of welfare"}

This last point is further illustrated, for care and domestic workers, by Mara Tognetti Bordogna (2011) on the basis of a qualitative enquiry conducted with 682 migrant domestic and care workers, of whom 12 per cent were Ukrainian. Interestingly it emerged that when migrant care workers came into contact with the Italian health services it was typically in the interest of the person they take care of, rather than for themselves. Beside their possession of a formal qualification, it is true that these women are usually those who carry on pharmaceutical therapies, sanitary interventions, assistance in rehabilitation and medical checks for their care-receivers. Especially in case of emergencies, they are the ones communicating with doctors and nurses and implementing their prescriptions (Tognetti Bordogna, 2011, p. 45).

It is in this sense that the employment of migrant care workers is a "resource" for Italian welfare, providing an assistance that is continuous and personalised with relatively small costs for Italian families. In fact, the Ministry of Labour estimated that the Italian state is saving six billion annually, thanks to the work of these women.

On the other hand, Tognetti Bordogna shows that the strong majority of these workers have difficulties in accessing the Italian health sector because of language, especially in the case of people with low-medium educational background. The percentage of care workers who resorts to Italian public service is only 61.2 per cent.

Here, foreign women workers, particularly Eastern Europeans and within that category particularly Ukrainians and Moldovans are seen as "active providers" of welfare giving care and sanitary assistance to those in need. 


\subsection{Integration of migrants in Italy}

\subsubsection{Economic assimilation of foreign workers}

The empirical research on wage and employment assimilation of migrants shows that migrants never assimilate to native levels either in terms of wages or employment31. Figure 4.1 shows how the wage differentials between natives and foreign nationals of similar characteristics exist at the threshold of employment and that these increase as long as migrants reside and work in the destination country. Unfortunately these analyses do not cover the family sector that is the main provider of employment for female EaP migrants. Thus it can be helpful only for the male component, namely the Moldovan man employed in the manufacturing industry in Emilia Romagna.

From the more fragmented evidence in the family sector what emerges is that migrants have few career opportunities and chances to increase wages given the structure of the sector. Their main career improvement is in moving from the "live-in care givers" to the less demanding "home services sector" where, however, freedom is exchanged for more expenses and not always for a higher income. The turnover in this sector is also very high because the "live-in care givers" is not a tenure tract position inside one family and the house service presents large turnover or shift work in different houses.

Fig. 4.3 - Foreign-native differentials in wages and days worked by ethnic groups with increasing experience in the labour market

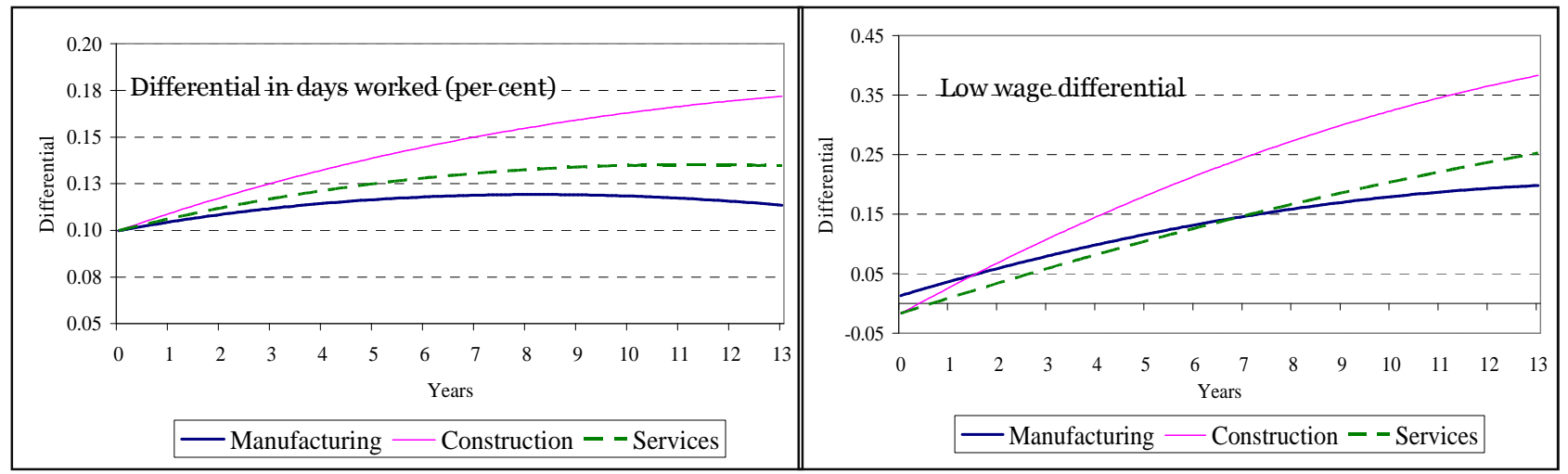

Source: Venturini and Villosio, 2008

Fig. 4.4 - Foreign-native differentials in wages and days worked by sectors with increasing experience in the labour market
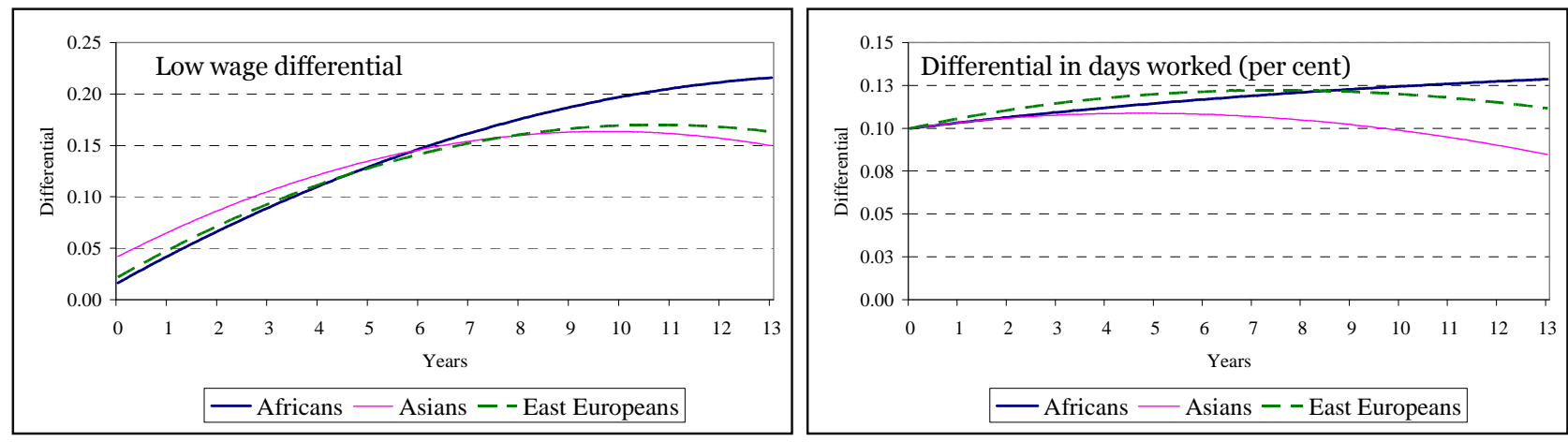

Source: Venturini and Villosio, 2008

${ }^{31}$ See Venturini and Villosio (2008); Venturini, Villosio, Strom and Fainim (2010). 


\subsubsection{Socio-economic, cultural and political integration}

An overall integration index has been suggested by Cesareo and Blangiardo (2009) in their Integromentro. In 2009, 12.000 regular and irregular foreign nationals have been interviewed in all the Italian regions (see par. 2.8 on irregular migration for the methodology applied) and have been collected information on their characteristics and integration following four main dimensions: economic, political, social and cultural.

- Economic integration (EI) refer to housing, work and saving capacity ;

- Social integration (SI) refers to friendly relations, participation in associations, Italian lifestyle acceptance and liking levels, propensities and intentions;

- Cultural integration (CI) refers to knowledge and use of the Italian language, interest in Italian events, access to information, sense of belonging to the Italian society, migrants' self-perception of their well-being in Italy and their sharing of some integration ideals;

- Political integration (PI) refers to legal status, registration with the Registry Office, and opinions on the importance of citizenship.

One of the main difficulties depends on the need of attribute a quantitative score to qualitative features. ISMU operated by ranking on a scale the integration conditions and give them a score, constructing an integration index for each of the four dimensions, standardised from o to 1 . The "overall integration index" is just the simple average between them. Figure A.8, in the Annex, reports in details the variable used. Table 4.2 shows the different integration ranking of the most important migrant communities. Moldovans and Ukrainians are always very close to each other, with below average scores save for the cultural one, a result of the higher level of education among EaP migrants. The low level of the economic share is dependent upon the type of jobs in which they are employed that does not provide any career progression and does not reward their skills but, especially for Ukrainians, suits their temporary migration project.

The social share variable measures social interaction with natives as a function of the seniority of migration. Of course, the type of job as residential caregiver reduces possible interactions outside the family where the migrant is employed. The political share, instead, measures the interest in the country of destination as final residency or the still strong attachment to the country of origin. The low political integration is a consequence of a low interest in acquired Italian citizenship and of the widespread irregular status. 
Tab. 4.2 - Integration index by country of origin and fields, 2009

\begin{tabular}{|c|c|c|c|c|c|c|c|c|c|c|}
\hline \multirow[t]{2}{*}{ Citizenship } & \multicolumn{2}{|c|}{ Cultural share } & \multicolumn{2}{|c|}{ Social share } & \multicolumn{2}{|c|}{$\begin{array}{c}\text { Index } \\
\text { Political share }\end{array}$} & \multicolumn{2}{|c|}{ Economic share } & \multicolumn{2}{|c|}{ total } \\
\hline & Rank & $\%$ & Rank & $\%$ & Rank & $\%$ & Rank & $\%$ & Rank & $\%$ \\
\hline Brazil & 1 & 0,64 & 5 & 0,51 & 4 & 0,52 & 3 & 0,60 & 1 & 0,57 \\
\hline Domin. Rep. & 5 & 0,54 & 2 & 0,53 & 1 & 0,59 & 14 & 0,53 & 2 & 0,55 \\
\hline Albania & 2 & 0,57 & 4 & 0,52 & 6 & 0,52 & 8 & 0,56 & 3 & 0,54 \\
\hline Russia & 3 & 0,57 & 1 & 0,55 & 13 & 0,48 & 6 & 0,56 & 4 & 0,54 \\
\hline Ecuador & 4 & 0,56 & 14 & 0,47 & 17 & 0,47 & 2 & 0,63 & 5 & 0,53 \\
\hline Philippines & 6 & 0,54 & 8 & 0,49 & 7 & 0,52 & 11 & 0,54 & 6 & 0,52 \\
\hline Peru & 8 & 0,53 & 10 & 0,48 & 12 & 0,49 & 4 & 0,58 & 7 & 0,52 \\
\hline Eritrea & 9 & 0,53 & 3 & 0,52 & 2 & 0,59 & 24 & 0,44 & 8 & 0,52 \\
\hline Poland & 7 & 0,54 & 12 & 0,48 & 11 & 0,50 & 13 & 0,53 & 9 & 0,51 \\
\hline Romania & 10 & 0,52 & 15 & 0,47 & 9 & 0,51 & 15 & 0,52 & 10 & 0,50 \\
\hline Kosovo & 14 & 0,50 & 19 & 0,45 & 16 & 0,47 & 7 & 0,56 & 11 & 0,50 \\
\hline Tunisia & 12 & 0,50 & 13 & 0,47 & 10 & 0,51 & 21 & 0,48 & 12 & 0,49 \\
\hline Morocco & 16 & 0,46 & 11 & 0,48 & 8 & 0,51 & 20 & 0,49 & 13 & 0,49 \\
\hline Macedonia & 20 & 0,43 & 20 & 0,45 & 5 & 0,52 & 12 & 0,54 & 14 & 0,48 \\
\hline India & 15 & 0,47 & 9 & 0,48 & 24 & 0,42 & 9 & 0,55 & 15 & 0,48 \\
\hline Egypt & 17 & 0,46 & 18 & 0,45 & 14 & 0,48 & 16 & 0,52 & 16 & 0,48 \\
\hline Pakistan & 23 & 0,41 & 17 & 0,45 & 18 & 0,47 & 5 & 0,57 & 17 & 0,48 \\
\hline Ghana & 22 & 0,41 & 7 & 0,50 & 3 & 0,53 & 23 & 0,46 & 18 & 0,47 \\
\hline Moldova & 11 & 0,51 & 24 & 0,44 & 23 & 0,42 & 17 & 0,51 & 19 & 0,47 \\
\hline Sri Lanka & 19 & 0,44 & 23 & 0,44 & 21 & 0,44 & 10 & 0,54 & 20 & 0,47 \\
\hline Ukraine & 13 & 0,50 & 22 & 0,45 & 25 & 0,41 & 18 & 0,51 & 21 & 0,47 \\
\hline Nigeria & 21 & 0,42 & 6 & 0,51 & 15 & 0,47 & 25 & 0,43 & 22 & 0,46 \\
\hline China & 25 & 0,29 & 25 & 0,41 & 20 & 0,45 & 1 & 0,67 & 23 & 0,45 \\
\hline Senegal & 18 & 0,46 & 16 & 0,46 & 22 & 0,42 & 22 & 0,47 & 24 & 0,45 \\
\hline Bangladesh & 24 & 0,39 & 21 & 0,45 & 19 & 0,46 & 19 & 0,50 & 25 & 0,45 \\
\hline Total & - & 0,49 & - & 0,48 & - & 0,49 & - & 0,53 & - & 0,50 \\
\hline
\end{tabular}

Source: Cesareo and Blangiardo, 2009

\subsubsection{Integration policies}

To explore efforts to improve integration of migrants at the institutional level in Italian society, we refer to the 2011 edition of the Mipex Index. Although this Index generally values Italian policies in positive terms, it shows that things have got worse since the promulgation of the Security Package in 2008.

The index, in fact, gives a double-sided assessment of policies that concern family reunion in terms of eligibility, security of status and rights. The acquisition of conditions is considered in negative terms, since prospective sponsors must meet disproportionately high income and accommodation requirements to reunite their families. The promotion of long-term residence is also double-edged, since, on the one hand, its conditions are favourable to integration in comparison with other countries. But, on the other, the requirements are very limited. The Security Package imposes language and integration tests following the model of a "points-based system" that is reckoned to discourage or to delay integration.

Education is the field in which Italian policies perform worse since migrants at school are targeted as a "problem group" and there are not opportunities for intercultural education. No special training is required for teachers and immigrant languages are absent from curricula. In addition, a 2010 protocol states that there cannot be more than 30 per cent non-Italians in a class. Equally negative is the lack of political participation amongst migrants, since Italy does not offer enough political opportunities and the right to vote is only given to a very restricted group. 
Finally, Italy is criticised for having the weakest equality policies in Europe. The state has no positive duty to promote equality in its own actions and the Office for Racial Discrimination cannot instigate or engage in proceedings. Yet, EU law on antidiscrimination has been implemented and migrants can enforce their rights in all areas of life.

\subsubsection{Perceptions on immigration and ethnic-based discrimination in Italy}

In order to understand the reality faced by migrants working in Italy, is it important to broaden our views on the general perceptions on the part of Italians and migrants for migration issues and the risks of discrimination there.

For the present contribution, three different data sets seem to be relevant. The first refers to the Transatlantic Trends Immigration survey which assesses, on the basis of extensive CATI-based interviews, the opinions, fears and worries of people in the United States and some European countries (Italy, Germany, France, Spain and the United Kingdom). In the table below, one may find a selection of the results concerning four different questions, comparing the answers from Italy with the average from other European countries. The first interesting result concerns the evident belief, on the part of Italians, that migration is more of a problem than an opportunity: the answers to question 1 indeed show that 52 per cent of Italians see immigrants as "problems". Moreover, Italians seem generally more worried than other Europeans about migration when this takes place irregularly (question 2) and when it relates to the presence of irregular migrants in the country (question 3). Yet, question 4 shows a generally positive attitude towards foreigners: Italians feel more responsible than other Europeans to host people escaping from war and poverty. This data is particularly significant as it was collected in 2011 at the time of the Arab Spring when many Northern African were making landfall on the Italian coasts.

Tab. 4.3 - Perceptions of immigration: comparison between Italy and other European countries (UK, France, Germany and Spain)

\begin{tabular}{|c|c|}
\hline \multicolumn{2}{|c|}{ 1. People believing that immigrants are a problem rather than an opportunity } \\
\hline Average in Europe & 48 per cent \\
\hline In Italy & 52 per cent \\
\hline \multicolumn{2}{|c|}{ 2. People worried about irregular migration } \\
\hline Average in Europe & 67 per cent \\
\hline In Italy & 80 per cent \\
\hline \multicolumn{2}{|c|}{ 3. People worried about the presence of irregular migrants } \\
\hline Average in Europe & 67 per cent \\
\hline In Italy & 80 per cent \\
\hline \multicolumn{2}{|c|}{ 4. People willing to host migrants escaping from poverty and war } \\
\hline Average in Europe & 58 per cent \\
\hline In Italy & 68 per cent \\
\hline
\end{tabular}

When it comes to the possibility of discrimination or of being assaulted it is interesting to look at data from EU-MIDIS project run by FRA. The following table presents a 
comparison between the results of the two surveys, on a selected number of questions.

Tab. 4.4 - Perception of discrimination based on ethnic or immigration origin as being "very" or "fairly" widespread, EU-MIDIS. All-Italy based survey respondents

\begin{tabular}{|l|l|}
\hline Albanian & 76 per cent \\
\hline North African & 94 per cent \\
\hline Romanian & 77 per cent \\
\hline $\begin{array}{l}\text { 2. Discrimination experiences on more than one grounds, } \\
\text { EU-MIDIS. All Italy based survey respondents }\end{array}$ & months, \\
\hline Albanian & 14 per cent \\
\hline North African & 55 per cent \\
\hline Romanian & 16 per cent \\
\hline
\end{tabular}

Source: FRA, EU-MIDIS: European Union minorities and discrimination survey, 2010

The data show that Northern African are those perceived as to be most "at risk" of discrimination, followed by Romanians and Albanians (question 1). The results are explained by the strong negative stigmatisation of these communities in Italy, in connection with Islamophobia (in the case of Northern African) and anti-Romanian sentiments connected with criminalisation within this group. Question 2 confirms the data on the discriminatory attitudes towards Northern Africans by emphasising the multiple character of their (possible) discrimination: not only as based on ethnic background, but also religion.

Tab. 4.5 - Area of origin of the victims of discrimination. Comparison 2010-2011

\begin{tabular}{|l|l|l|}
\hline & 2010 & 2011 \\
\hline Africa & 12.6 & 9.7 \\
\hline North Africa & 20.9 & 16.6 \\
\hline South America & 9.8 & 13.8 \\
\hline North America & 5.1 & 0.5 \\
\hline Europe & 1.4 & 3.7 \\
\hline Eastern Europe and Balkans & $\mathbf{2 3 . 3}$ & $\mathbf{2 4 . 9}$ \\
\hline Italy & 27 & 30.9 \\
\hline Total & $\mathbf{1 0 0}$ & $\mathbf{1 0 0}$ \\
\hline
\end{tabular}

Source: UNAR/IREF-ACLI, 2012
These data are well complemented by the insights produced by the Italian National office against discrimination (UNAR) which reports information on the requests of protection against abuses every year. Data for 2010 and 2011 confirm the predominant role of Eastern Europeans as those complain about acts of abuse. This data, in a sense, contradicts the one from EU-MIDIS by emphasising discrimination on Eastern Europeans rather than Northern Africans.

The discrepancy is easily explained by taking into consideration the fact that Eastern Europeans turning to the UNAR offices and call-centres are not "representative" of the actual experience of migrant groups in Italy, but rather signal the capacity of this group to react to offences, by issuing complaints against them.

Unfortunately no specific reference is made to migrants from EaP partner countries even if Moldovans are frequently lumped together with Romanians, while the other communities are too small to figure independently in the surveys. 


\subsection{Effects of migration in the sending countries}

\subsubsection{Migration and the labour market}

The ETF has organised research on skill mismatch with papers on Ukraine and Moldova. Both papers produced important evidence for skill mismatches. But it was not clear if migration was decided by the skill mismatch or whether it produced skill mismatch. The evidence suggests that migrants have moved abroad in search of income given the poverty increases and price growth (especially in Moldova) which has reduced their purchasing power. From other reports there is no evidence of skill mismatches created by emigration per se, even if the outflows are frequently made by medium and highly-skilled workers ${ }^{2}$ and even if their departure can reduce growth.

\subsubsection{Migration and welfare providers}

The country of origin has a similar problem with aging populations. 33 Indeed, the share of people above 60 is only a little lower than the European average: EU27 22 per cent, Ukraine 20.3 per cent, Georgia and Belarus 18 per cent, Moldova and Armenia 13 per cent with the exception of 9 per cent for Azerbaijan and the forecast for the year 2020 to 2050 indicates a rapid growth also for Azerbaijan. We must also remember the age composition of the migration flows which is particularly mature in the case of Ukrainian migrants and Georgians (they are typically in the 45-55 years old group): the problem of providing help to old-aged person becomes increasingly relevant then. ${ }^{34}$ The economic transition has increased the poverty and reduced the services traditionally provided by the state and the problems remains for families which are under pressure as well as providing income.

\subsubsection{Migration and remittances 35}

Remittances represent at least 25 -36 per cent of GDP in Moldova, 7-18 per cent in Armenia and 6 per cent in Georgia and much less in the other countries. Remittances brought back to Ukraine are the largest in absolute terms. Moldova is, instead, the thirdlargest recipient of remittances in the world. They are used mainly for everyday consumption (30-40 per cent, 77 per cent in Azerbaijan) but also for the education of children, even grown children who are at university. They have also transformed the construction sector creating, especially in Moldova, terrific price increases. Due to the inefficiency of the banking system they also replace direct financing in economic activities and reduce poverty. The family which receives remittances improves their income position but, for example, in Armenia remittances play a regressive role, for the families who receive more remittances are the relatively richer ones.

\footnotetext{
$3^{2}$ See also ETF Labour markets and employability trends and challenges in Armenia, Azerbaijan, Belarus, Georgia, Moldova and Ukraine, and CARIM EAST researches Efendiyev (2012), Oprunenko (2012), Bobrova (2012)

33The population growth is 1.1 in Azerbaijan but 0.2 in Armenia, and negative in all the other countries -0.2 Belarus, -o.8 Georgia, -0.9 Moldova, -0.5 Ukraine, see Chobanyan and Gevorgyan (2012), Poznyak (2012).

34 In Tolstokorova (2009).

35 See Kupets (2012), Zurabishvili (2012).
} 


\subsubsection{Welfare for returned migrants ${ }^{3}$}

As shown in previous section emigration from EaP countries is frequently temporary. As mentioned before it is derived from the experience of free mobility with the Russian Federation which created the habit of temporary migration. The example of Ukrainian migration to Italy which is temporary in its nature, underlines the necessity of granting the wellbeing of the returned migrants, particularly women in their fifties who depend more on their pension than on the possibility of finding a job. The structure of the pension systems is crucial then in both the destination and in the sending country.

Many women migrants do not get a pension when they return home because they do not reach the minimum vesting period of paid contribution in the destination country. The length of the vesting period takes into account the total value of the pension that the migrants receive at the end of his or her working life in the destination country which should be high enough to let him or her have a decent life. Given the differences in living costs a reduction in the vesting period and a lower pension would be better.

An additional problem is the portability of pension rights which in general is granted trough bilateral agreements, but which is based on the solvability of the pension system in the sending country.

If it is not so reliable and if the country is revising the benefits for economic recessions, a better solution would be, instead of capitalising the benefits, to transform it into private insurance which grants a small remuneration each month. This second solution is preferable to the first because, as Tolstokorova's report37 points out, the main risk that the returned woman migrants face is the end of their savings and a push by the family to move abroad again.

\subsection{Conclusion}

This section has dealt with the effects of migration to Italy, focussing on the flows from EaP countries. Hypotheses on these effects were suggested both with regard to the countries of origin, and with Italy as a country of destination.

Italy is affected by migration at several levels. At the first level there is the possible competition and influence on wages of Italian workers. Here migrants who, as in the case of EaP nationals, are employed in low-skilled sectors do not compete but actually complement the native workforce. This is particularly so in the case of migrants working in the care and domestic sector who allow Italian women to increase their participation in the labour market by relieving them of household commitments. Migrants from abroad seem rather to compete with internal migrants, i.e. people from the south of Italy looking for work in the north.

\footnotetext{
${ }^{6} 6$ Yeganyan (2012), Ganta (2012).

37 CARIM (2012).
} 
An evaluation of the costs and benefits of migration to Italy is provided in section 4.3 where the discussion turns on the shifting position of migrants as welfare "users" and "providers". From an analysis of the current debate, we conclude that the contribution of migrant women domestic workers as welfare "providers" stands far higher than their use of the Italian welfare.

The section also deals with issues of integration, pointing to the lack of adequate policies on equality in Italy. Similarly, the chances of integration for migrants, from the point of view of career improvement are largely negative (see par. 4.4.1). On the basis of the Integrometro survey, we also show that Ukrainians and Moldovans perform worse than other migrant groups in relation to social, economic and political integration, due to them being channelled into occupations such as domestic and care work.

As to any impact in the emigration country, the section focussed on the importance of migrant remittances for EaP countries and found a possible vulnerability in the inadequacies of pension portability between Italy and EaP countries. 


\section{Is there demand for EaP migrants?}

Will migration from EaP countries continue in the future? Is there demand for migrants? These are the questions which we are going to answer in this section.

As was stressed above, EaP migrants do unskilled jobs in Italy. Typically, female EaP migrants are employed in the family sector and men in construction. In both sectors upgrading is limited. Ukrainians and Georgians tend to remain as residential care givers a more demanding job - while Moldovans have moved into what amounts to less demanding non-residential household work.

The forecasts here should consider the structural demand of foreign labour in the Italian economy. This depends on the aging of population which engenders a specific demand in terms of services for old aged persons, and the reduction of the domestic labour supply. The recession reduces the total demand of labour and probably spurs an upgrading in production technology or a downgrading in the less formal sector.

\subsection{CEDEFOP Skill labour demand in Europe}

The CEDEFOP forecasts on labour demand are divided by sector and skill and where they show that even if there is a reduction in the demand for low-skilled workers, the replacement demand (namely the number of people that will retire) is so large that the total demand will not decline a great deal. This implies that the demand for unskilled workers will continue at a slower pace in Italy.

Fig. 5.1 - Net employment change by broad occupational groups, 2010-2o, Eu-27+

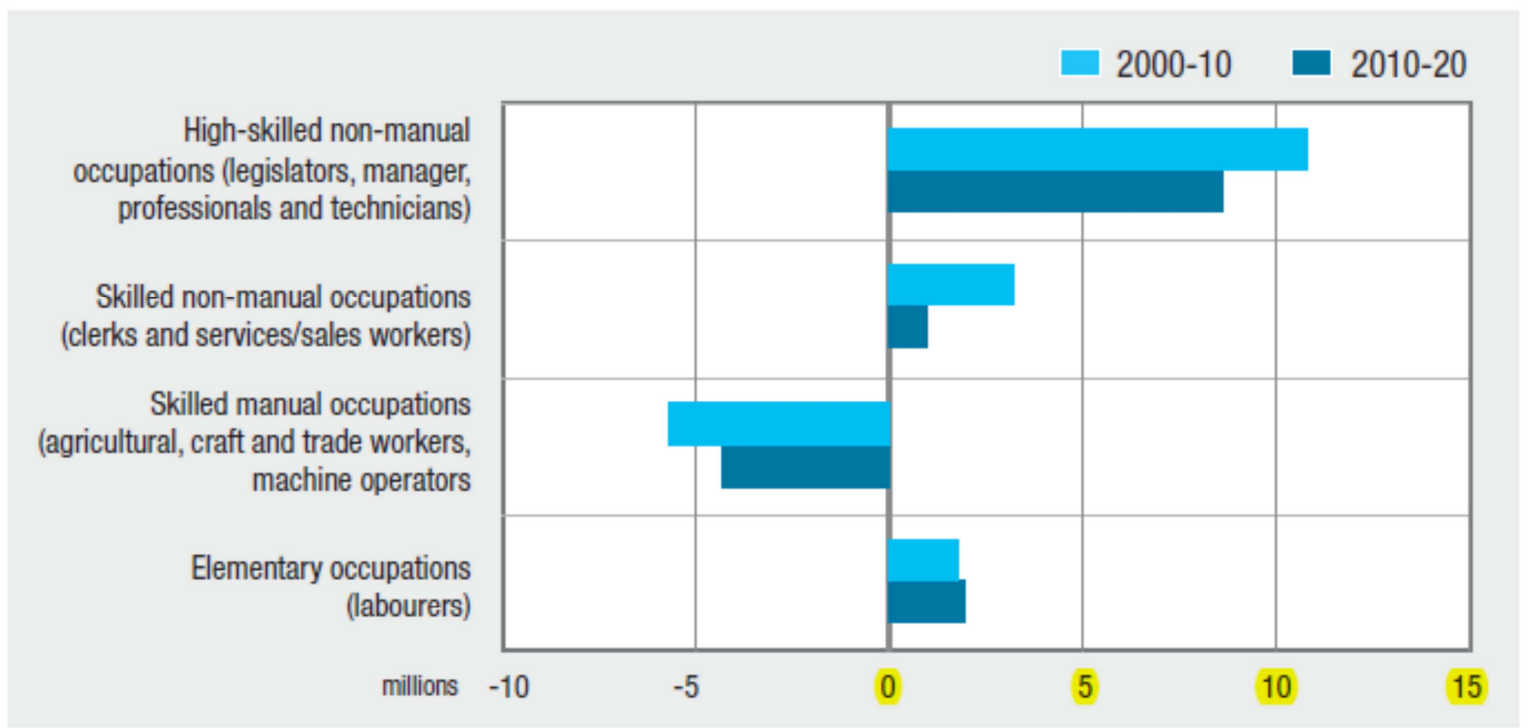

Source: Cedefop (IER estimates based on E3ME, EDMOD and RDMOD). 


\subsection{The forecast of employment in Italy ${ }^{3} 8$}

In Italy there are two important surveys. The first is done by the national statistical office, Istat, on firms with more than 10 employees, on the vacancies (named VELA) which exist since 2003. The second is the Excelsior survey which covers all the firms registered at the Chamber of Commerce with more than 50 employees and only a sample of firms with fewer than 50 workers.

Both analyses are very accurate but none of them cover demand in the household sector which is the most important for EaP migrants. We present their results keeping in mind that the main driver of migration from the countries studied here is missing.

The analyses of the vacancies (VELA) shows a rapid decline in job offers both in the industrial, services sectors and also in construction from 2008, which, subsequently increase again at the beginning of 2010. Thus even if the number of smaller firms is very large in the construction sector, the aggregate evidence supports a limited decline in this sector where most Moldovan men are employed.

The Excelsior survey on private firms also has a section on foreign employment. Firms which have an open demand for immigrants are 21 per cent, with an increase relative to the previous year. The larger the firm, the larger the demand for foreign workers. The demand is spread across all sectors (19.7 per cent) in construction and (22 per cent) in services, in all parts of Italy but more in the north: 22.6 per cent north-west, 24.5 per cent north-east, 23.2 per cent in the centre and 16.3 per cent in the south. The sector with the highest demand is the tourism, restaurants and hotels sector with 40 percent, while the financial sector is the lowest.

Fig. 5.2 - Vacancies rate in manufacturing and construction, 2004-2010(a) (quarterly data, percentage)

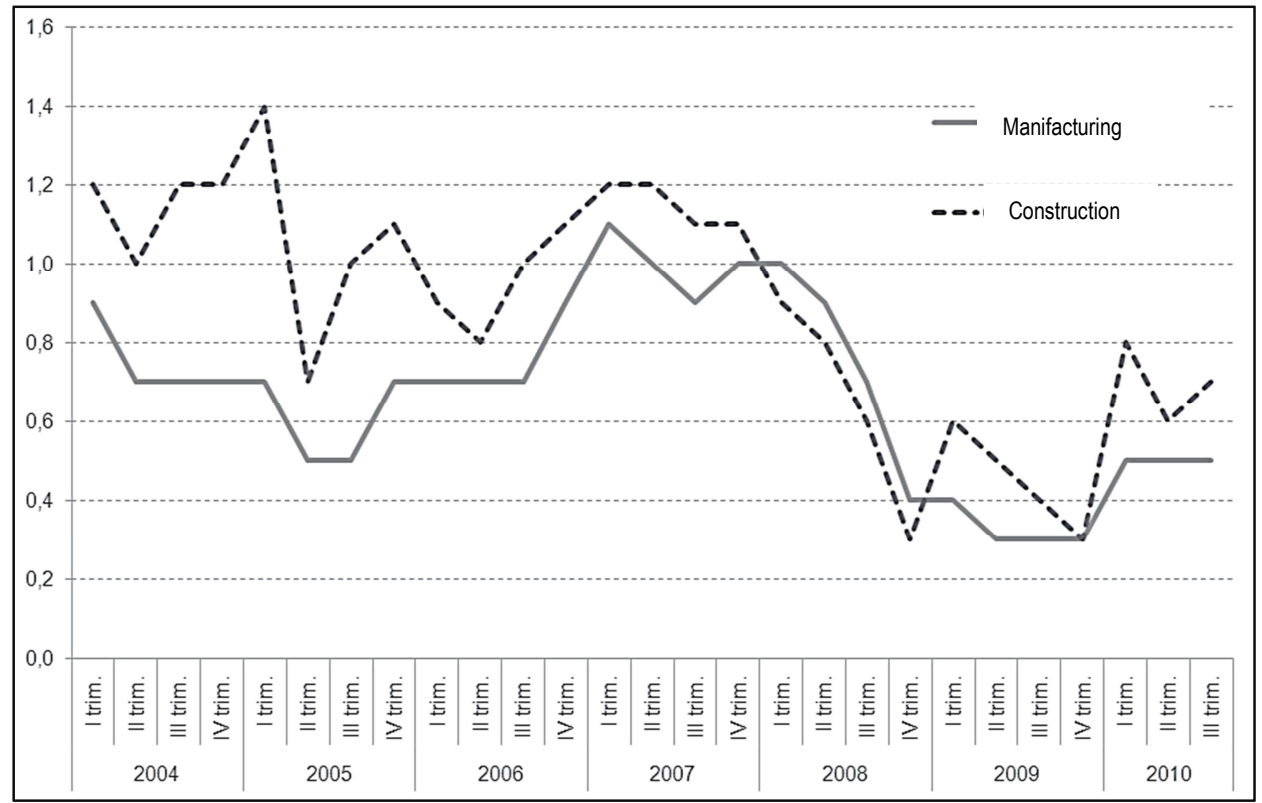

Source: Ministero del lavoro, 2011.

Notes: (a) 2010: provisional estimates.

${ }^{38}$ See Ministero del lavoro (2011). 
If, however, we focus only on non-seasonal employment the health, social services and private health sector is the highest in the list. The demand of foreign labour are 9 per cent highly skilled, 31.6 per cent medium skilled and 6o per cent low skilled.

The 15 positions most in demand for non-seasonal foreign workers are cleaners first, construction workers in second, and waiters and similar as third. Three main sectors dominate demand: the services to aged persons, restaurants/bars and construction.

Tab. 5.1 - Non-seasonal hiring of immigrants scheduled by firms in services sector, bv subsector ( $\max$ hvpothesis, percentage on total hiring), 2008 - 2010

\begin{tabular}{|l|l|l|l|}
\hline Sector & $\mathbf{2 0 0 8}$ & $\mathbf{2 0 0 9}$ & $\mathbf{2 0 1 0}$ \\
\hline Health, social assistance and private care services & 38,0 & 37,6 & 43,0 \\
\hline Tourism, hotels and catering & 24,8 & 21,3 & 29,8 \\
\hline Services for firms and private & 38,3 & 31.8 & 29.7 \\
\hline Transportation, logistics and storage & 23.8 & 14.5 & 19.4 \\
\hline Education and private training & 16.6 & 11.7 & 17.8 \\
\hline Culture, sport and private services & 17.4 & 14.4 & 17.0 \\
\hline Trade and repair of vehicles & 10.3 & 7.7 & 13.0 \\
\hline Retail trade & 13.3 & 9.6 & 11.8 \\
\hline Wholesale trade & 11.7 & 12.5 & 11.5 \\
\hline Advanced service for firms & 9.1 & 9.0 & 8.3 \\
\hline Professional consultancies & 3.0 & 5.2 & 7.7 \\
\hline ITC and telecommunication services & 9.2 & 11.0 & 5.4 \\
\hline Media and communication & - & - & 3.8 \\
\hline Finance and insurance & 5.4 & 5.3 & 3.0 \\
\hline Total services & 19.9 & 17.5 & 19.4 \\
\hline Total industry and services & 20.3 & 17.0 & 19.2 \\
\hline
\end{tabular}

Source: Ministry of Labour, 2011.

\subsection{Forecasts from the Ministry of labour}

The Ministry of Labour forecasts the coming demand of labour by adopting strong hypothesis about future immigration patterns. The first scenario ( $\mathrm{S} 1$ ) is based on complete closure to immigration flows and the labour force is determined only by recent birth and mortality rates; the second scenario (S2) is based on the hypothesis of constant flows at the same level as the present ones; in the third scenario (S3) the variation is constant and the last scenario $\left(\mathrm{S}_{4}\right)$ has the working population at a constant level in which the inflows just replace the existing level.

The picture below shows the results, with the declining line S1 showing the closure scenario and $S_{2}$ and $S_{3}$, very similar with $S_{4}$ in between them.

The picture strongly underlines the importance of immigration for the native population and the need of migration for the country.

No forecast exists yet concerning the size of permanent and temporary migration. This second type of migration is in line with the idea that the country of origin also needs population and the human capital of the labour force thus represents a larger share if it involves temporary immigration. The destination countries try as well to get only labour so 
the temporary migration project fit both interests. The projection of the Ministry of Labour, however, forecast, seasonal and non-seasonal employment at 75,00o for seasonal and 100,000 for seasonal in the most optimistic scenario and 42,750 and 70.950 in the least optimistic.

Fig. 5.3 - Residents (thousands) and demographic forecast in fours scenarios. 2000-2020

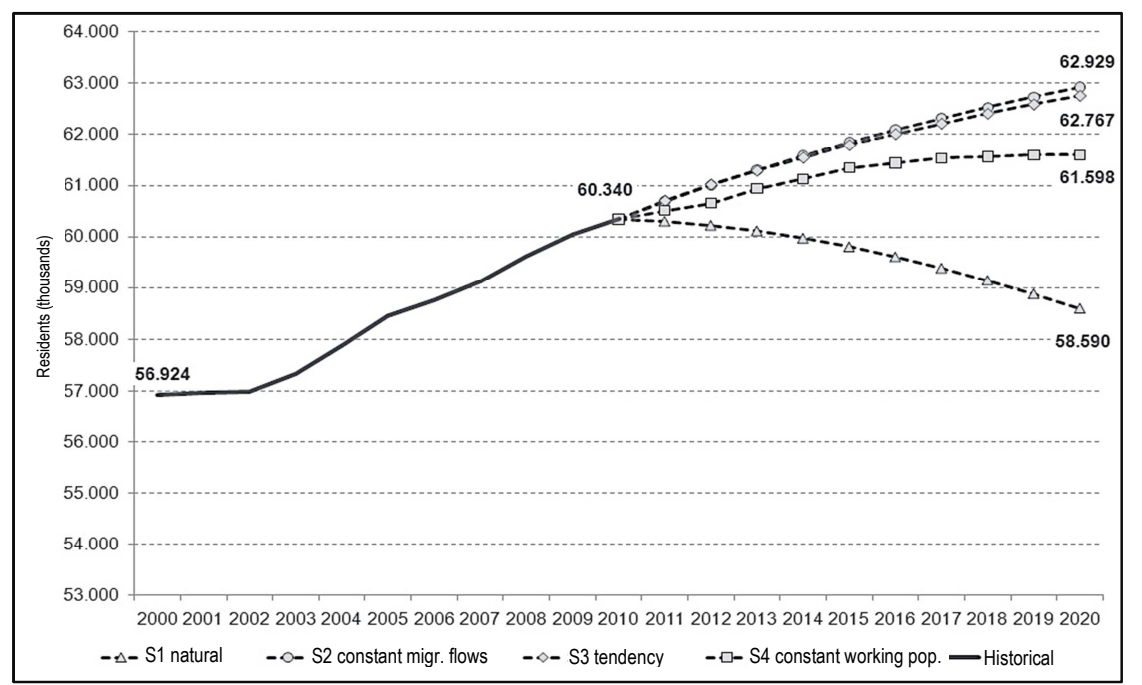

The Ministry of Labour have commissioned a research team to forecast the number of foreign workers, but at the moment the results are not available. A "back of the envelope" calculation makes a ratio of the aging population at 75 and older to the number of residential care givers. But this is inappropriate because it underestimates the increase in life expectancy and the Source: Ministero del lavoro, 2011. large mobility of labour forces.

If, however, there is a problem in defining demand, even more undefined is supply because the supply of EaP migrants is declining given the simultaneous aging of the population there.

\subsection{Conclusion}

This section summarises the forecast for the demand of immigrants from EaP countries in Italy. It has been shown both by CEDEFOP and by national estimates (VELA, Excelsior, Ministry of Interior) that the demand for unskilled workers will continue. This is true of all sectors, but particularly in the construction (relevant for Moldovan men) and service sectors dominated by social and private health services. However these reports lack specific estimates on demand in the household sector, which is the most important for female EaP migrants. 


\section{Legal framework on labour migration}

\subsection{Overview}

As was noted in Sections 1 and 2.8, Italy was largely unprepared to regulate the flows of migrant workers which started in the mid 1970s. As Del Boca and Venturini (2005) pointed out, Italy lacked adequate legislation, administrative structures and financial previsions. As a consequence, several reforms of Italian migration law were enacted in the following years, in which labour migration was central. A first law (Fosco Law, 1986) was soon followed by the Martelli Law (1990), and then by the Turco-Napolitano Law (1998) and finally by the Bossi-Fini Law (2002), with an increasing emphasis on the management of migration through flow planning.

At present, the possible motivations which entitle migrants to a regular permit to stay, in Italy, are:

a. business, religion, tourism and study (a limited number of study-permits can be converted into permits for work);

b. family reunification (when the sponsor fulfils requirements on income and accommodation);

\section{c. asylum and international protection;}

d. and, finally, seasonal and non-seasonal work (on the basis of quotas set by the government according to the need of the labour market).

A major option in migration to Italy remains irregularity, with people entering illegally or remaining after their (regular) permit has expired, while eventually waiting for an amnesty or for regularisation to take place.

In general, the impression is that, in Italy, migration issues have never ceased to be considered as "emergencies": in 23 years Italy has adopted four different laws on migration, and has offered amnesties six times (1986, 1990, 1995, 1998, 2002, 2009).

\subsection{The quota system}

The first measure on planned flows took place in 1996.But it was only after the Bossi-Fini Law (2002) that quotas remained the basic channel for labour migrants to enter in Italy. The previous Turco-Napolitano Law (1998) indeed also foresaw the possibility of migrants arriving through the support of a "sponsor", but this opportunity is no longer in place.

The quotas are determined on the basis of the legal decrees issued every one or two years by the Italian Parliament, decrees which fix the maximum number of immigrants for seasonal and for non-seasonal work. Moreover, quota-decrees distinguish between different occupational sectors and countries of origin (see Table 6.1). These quotas are based on bilateral agreements which are in place (or that are soon going to be) between Italy and countries where there is strong migratory pressure. Since the promulgation of the Bossi-Fini Law, the functioning of the quota system has been integrated with the on-call principle, i.e. the requirement for each immigrant to be invited by his/her prospective employers. 
Figure 6.1. shows the variation in the number of migrants allowed to enter on the quota system between 1996 and 2012. The peak in 2006, 2007 and 2008 corresponds to the decision by the Prodi government to regularise irregular workers (see Einaudi, 2007). The year 2006 was a moment in which a large number of workers, especially women employed in the care and domestic sector, already present in Italy, applied for a regular permit "pretending" to be in their country of origin from which they were "called" by their prospective employer. The use of the quota system as a way to regularise workers that are already in the country, shows the inadequacy of the on-call principle, which remains a major brake on the implementation of Italian legislation on migration issues. Next to that, the determination of the numbers of workers "needed" is always far below the numbers actually required by companies and families willing to employ a migrant worker.

Fig. 6.1 - Planned flow 1996-2012

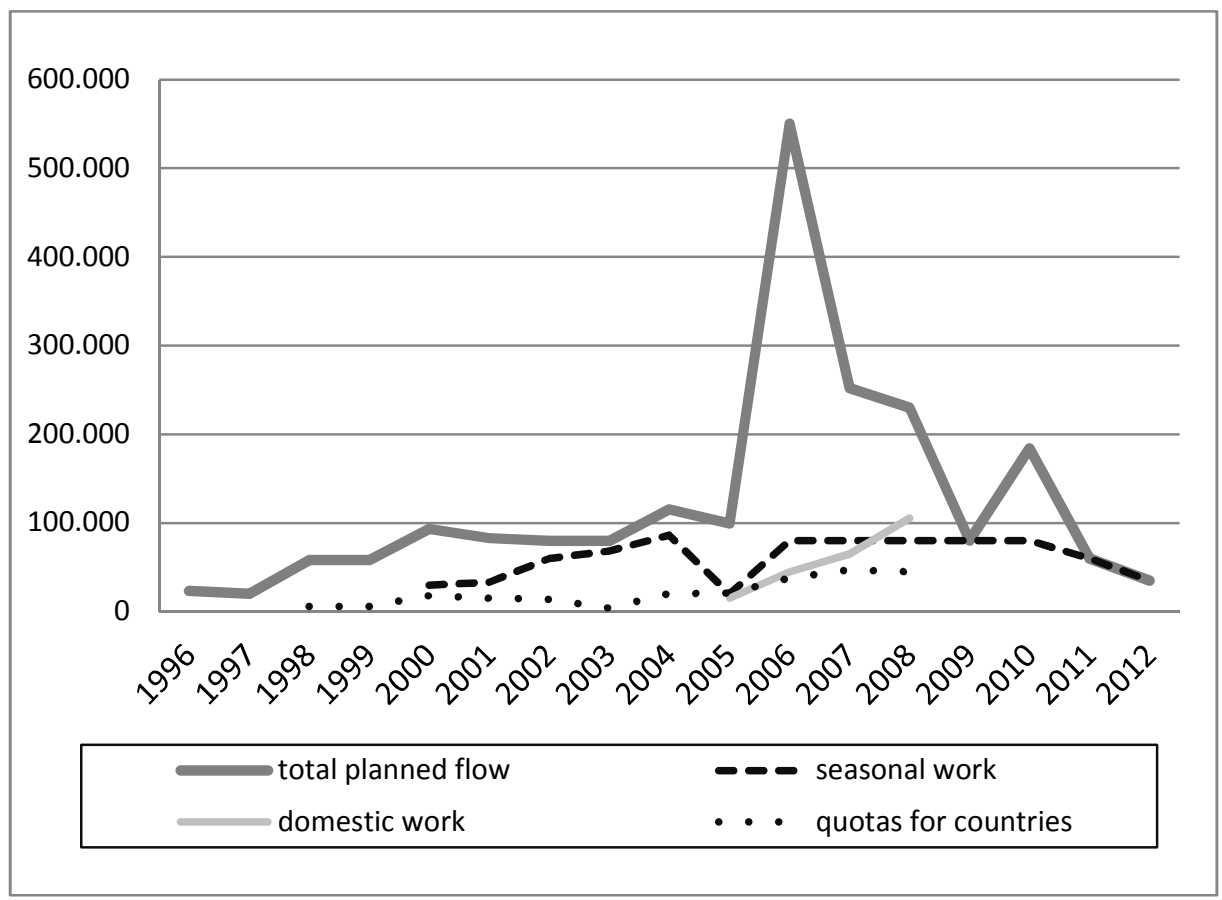

Source: Own elaborations based on data from Ministero del lavoro (2011) and Ministero dell'Interno (www.interno.it) 
Tab. 6.1 - Flows decrees 1996-2012: quotas and characteristics

\begin{tabular}{|c|c|c|c|c|c|c|c|c|c|c|c|c|c|c|c|c|c|}
\hline \multirow{2}{*}{$\begin{array}{l}\text { Non-seasonal work: } \\
\text { - Special quotas }\end{array}$} & 1996 & 1997 & 1998 & 1999 & 2000 & 2001 & 2002 & 2003 & 2004 & 2005 & 2006 & 2007 & 2008 & 2009 & 2010 (a) & 2011 & 2012 (b) \\
\hline & & & & & & & & & & & & & & & & & \\
\hline Albania & & & 3,000 & 3,000 & 6,000 & 6,000 & 3,000 & 1,000 & 3,000 & 3,000 & 4,500 & 4,500 & 4,500 & & 4,500 & & \\
\hline Morocco & & & 1,500 & 1,500 & 3,000 & 1,500 & 2,000 & 500 & 2,500 & 2,500 & 4,000 & 4,500 & 4,500 & & 4,500 & & \\
\hline Tunisia & & & 1,500 & 1,500 & 3,000 & 3,000 & 2,000 & 600 & 3,000 & 3,000 & 3,500 & 4,000 & 4,000 & & 4,000 & & \\
\hline Somalia & & & & & & 500 & & & & 100 & 100 & 100 & 100 & & 80 & & \\
\hline Egypt & & & & & & & 1,000 & 300 & 1,500 & 2,000 & 7,000 & 8,000 & 8,000 & & 8,000 & & \\
\hline Nigeria & & & & & & & 500 & 200 & 2,000 & 2,000 & 1,500 & 1,500 & 1,500 & & 1,500 & & \\
\hline Moldova & & & & & & & 500 & 200 & 1,500 & 2,000 & 5,000 & 6,500 & 6,500 & & 5,200 & & \\
\hline Sri Lanka & & & & & & & 1,000 & 500 & 1,500 & 1,500 & 3,000 & 3,500 & 3,500 & & 3,500 & & \\
\hline Bangladesh & & & & & & & & 300 & 1,500 & 1,500 & 3,000 & 3,000 & 3,000 & & 2,400 & & \\
\hline Pakistan & & & & & & & & & 1,000 & 1,000 & 1,000 & 1,000 & 1,000 & & 1,000 & & \\
\hline Philippines & & & & & & & & & & 1,500 & 3,000 & 5,000 & 5,000 & & 4,000 & & \\
\hline Ghana & & & & & & & & & & & 1,000 & 1,000 & 1,000 & & 2,000 & & \\
\hline Algeria & & & & & & & & & & & & 1,000 & 1,000 & & 1,000 & & \\
\hline Senegal & & & & & & & & & & & & 1,000 & 1,000 & & 2,000 & & \\
\hline India & & & & & & & & & & & & & & & 1,800 & & \\
\hline Peru & & & & & & & & & & & & & & & 1,800 & & \\
\hline Ukraine & & & & & & & & & & & & & & & 1,800 & & \\
\hline Nigeria & & & & & & & & & & & & & & & 1,000 & & \\
\hline Gambia & & & & & & & & & & & & & & & 1,000 & & \\
\hline Italian descendants & & & & & & & 4,000 & 200 & 400 & & & & & & & & \\
\hline Others (reserve) & & & & & 6,000 & 4,000 & & & 2,500 & 700 & 1,400 & 2,500 & & & 1,000 & & \\
\hline Total & & & 6,000 & 6,000 & 18,000 & 15,000 & 14,000 & 3,800 & 20,400 & 20,800 & 38,000 & 47,100 & 44,600 & & 52,080 & & \\
\hline - self employment & & & 3,500 & 3,500 & 2,000 & 3,000 & 3,000 & 800 & 2,500 & 2,500 & 3,000 & 3,000 & & & 4,000 & & \\
\hline - domestic work & & & & & & & & & & 15,000 & 45,000 & 65,000 & 105,400 & & 30,000 & & \\
\hline - construction & & & & & & (2000 & & & & & & 14,200 & & & & & \\
\hline - fishing & & & & & & 2,000 & & & & & 2,500 & 200 & & & & & \\
\hline - High qualified & & & & & & 3,000 & 500 & 500 & & 1,000 & 1,000 & 1,000 & & & & & \\
\hline Seasonal work & & & 20,000 & & 30,000 & 33,000 & 60,000 & 68,500 & 86,000 & 20,000 & 80,000 & 80,000 & 80,000 & 80,000 & 80,000 & 60,000 & 35,000 \\
\hline Total & 23,000 & 20,000 & 58,000 & 58,000 & 93,000 & 83,000 & 79,500 & 79,500 & 115,500 & 99,500 & 550,000 & 252,000 & 230,000 & 80,000 & 184,080 & 60,000 & 35,000 \\
\hline per cent special quota & & & 10.3 & 10.3 & 19.4 & 18.1 & 17.6 & 4.8 & 17.7 & 20.9 & 6.9 & 18.7 & 19.4 & & 29.3 & & \\
\hline $\begin{array}{l}\text { per cent seasonal work } \\
\text { per cent domestic }\end{array}$ & & & 34.5 & & 32.3 & 39.8 & $75 \cdot 5$ & 86.2 & 74.5 & 20.1 & 14.5 & 31.7 & 34.8 & 100.0 & 44.9 & 100.0 & 100.0 \\
\hline work & & & & & & & & & & 15.1 & 8.2 & 25.8 & 45.8 & & 16.8 & & \\
\hline
\end{tabular}

Source: Own elaborations on data from Ministero del lavoro (2011) and Ministero dell'Interno, decreti flussi (www.interno.it)

Notes: (a) the flow decree for 2010 was passed in December 2010, and became effective in 2011. (b) Until now (may 2012) only the decree for seasonal work has been passed. Apparently non-seasonal workers flow will not be planned in 2012, due to the economic downturn. 


\subsection{Bilateral agreement}

The first kind of bilateral agreements were readmission agreements, which Italy signed especially with North African countries. On the basis of these agreements, the country of origin is obliged to readmit their citizens when these are found to be present illegally in Italy, or if the same have committed a crime there. In return, the signatory State has a special quota in the planned flows. More recently, special quotas have been granted to countries with a "framework agreement" on employment (e.g. Moldova), which in most cases adds to the readmission agreement.

The establishment of agreements between Italy and other countries, and the consequent set up of a special quota for these nationals, represents the history of immigration to Italy: in 1998 quotas were already being set for Albanians, Moroccans and Tunisians. One has to wait until 2002 for quotas for Moldovans, which rapidly overtook other nationals in numerical terms. Ukraine, even though migration from this country started much earlier, only got special quotas from 2010 onwards.

At the comparative level, it is worth noting that the agreements signed by Italy with Moldova and Morocco are valid only concerning employment issues. The agreement with Egypt, meanwhile, also foresees the commitment of both countries to ensure that their citizens "who enter the Country for reasons of employment do not represent a threat to the security and public order of the host Country" (quoted in EMN, 2010).

A European Partnership agreement has been in place with Moldova, since 1998, while the Italo-Moldovan bilateral agreement was signed in 2003 and renewed in 2011. The last version aims to promote circular migration in order to reduce the impact of migration on the development of the sending country and to create language and professional training program on-site, taking into account the specific needs of the Italian labour market (EMN, 2012).

\subsection{Control and repression of irregular migration}

As we noted above, the planned flows system fails to guarantee that the only channel to enter the country is the regular one. On the contrary it shows itself to be inadequate, especially given the on-call principle. As a consequence, irregular migration is still widespread in Italy, even if public opinion often overestimates it (Del Boca and Venturini, 2005).

Frontier controls were strengthened by the Turco-Napolitano Law (1998), which also introduced the so-called $\mathrm{Cpt}$ (Centers for temporary permanence, later renamed Cie, Centers for identification and expulsion). These are centres created in order to detain irregular foreign nationals found on Italian soil, while waiting to repatriate them to their country of origin. The measures against those without stay permits became even stricter with the Bossi-Fini Law (2002), and especially with the so-called Security Package of 2008. These the main measure adopted: 
- aggravating circumstances of being irregularly on Italian soil, if a crime is committed;

- easier expulsion;

- extension of the maximum period in a Cie up to 6 months (extended to 18 months in 2011);

- introduction of the crime of "illegal migration", punishable by six months to four years in prison, or by a penalty of $€ 5$.000- $€ 10.000$. A sentence of the Court of Justice of the European Union (2011) made this point illegitimate with respect to European rights and thus ineffective;

- tightening of the penalty for who fosters illegal migration.

Some minor changes were introduced in 2011, especially in facilitating expulsions (see ISMU, 2011).

\subsection{Conclusion}

After a brief overview of the possible ways to legally enter and stay in Italy, this section illustrates the actual functioning of the legislation on labour migration to Italy.

Thus, it provides a detailed analysis of the planning of flows through quotas which is the central measure in the Italian management of migration. It also compares and assesses the relative significance of different motivations in applying for a residence permit (see figure 6.1). In this system a crucial role is played by the existing bilateral agreements between Italy and countries of origin, whose size and distribution in the allocation of specific country-quotas, is shown in Table 6.1. Moldova and Ukraine are the only two countries in the EaP region which can profit from a privileged quota of permits.

The section concludes with a brief outline of the measures in place for border control and for the repression of irregular migration which have been introduced in recent years. 


\section{Policy measures}

\subsection{Current measures: control and integration}

When we consider both the current Italian framework on migration, "control" and "integration" come up as the issues which receive most attention at the level of legislation, policy implementation and strategy.

In this light, the Italian Bossi-Fini law and the Security Package, responding to the guidelines set by the European Stockholm Protocol, emphasise the crucial role of new measures such as:

a. readmission agreements and mobility partnerships;

b. borders control and the sanctioning of irregular stayers;

c. integration programmes based on the acquisition of proficiency in the language, culture and civil codes of the host countries;

d. strengthening of relations with non-EU Mediterranean countries and SubSaharan countries.

As such EaP nationals who migrate to Italy, being for the most part labour migrant employed in the care and domestic sector, do not seem to receive adequate attention.

This point will be further illustrated in the following paragraphs by summarising the measures in place for labour migration, measures which might represent, in our view, possible obstacles for the full integration of labour migrants from EaP countries, in Italy.

\subsubsection{Labour migration: critical issues}

It was noted in Section 6 that, since 1996, labour migration to Italy has been managed through quotas set on the basis of the Governmental assessment of the needs of the Italian economy. Table 6.1 shows these quotas and their specification on the basis of nationality and occupation.

After almost 15 years, this mechanism has definite faults. In fact, strong discrepancies exist between the number of applications received, at the promulgation of the quotadegree, and the positions available.

Just to give an example, on the occasion of the last quota-degree (2010-2011):

- applications outnumbered the positions available four times over (411,117 applications against 104,080 positions)

- almost 75 per cent of applications concerned domestic and care work (304,144 applications were for domestic and care work)

- these 304,144 applications for domestic work were ten times higher than the quota available, which was for 30,000 job positions. 
- on the other hand, the requests for seasonal work were only 24,723 for the 80,000 positions available39.

Several criticisms have been made by scholars and experts against the inefficiency of this procedure in meeting the actual needs of the labour market in Italy (see Cesarini, 2011, EMN, 2011 and Zanfrini, 2012). These criticisms might be summarised as follows:

1. Numbers and typologies of the vacancies do not correspond to the actual requests from the labour market, probably because of a fundamental difficulty, on the part of the Government, to assess the actual needs of companies and of families willing to hire foreign workers. In particular, the annual levels do not seem to suit the fluctuation of the Italian economy.

2. Being that small the possibility of fitting most of the applications into the set categories does not correspond to reality. Applicants who follow the regular procedures are disadvantaged in comparison with those who, in some way, employ "fictive" tactics such as: pretending to be in the country of origin at the moment of the application, or applying for a different job from what they actually intend to do.

3. There is scarce attention to the training of workers: specific pre-departure training is largely absent; and systems of accreditation and certification of skills seem to fail to respond to the needs of workers and employers.

4. For the case of domestic and care workers, the on-call principle seems to be particularly disadvantageous, since it requires Italian households to employ someone they have never met before. This is hard to put into practice within such a peculiar employment type, where the personal dimension of the "match" between domestic/care workers and their employers is crucial.

\subsubsection{Specific obstacles for EaP nationals in Italy}

Against this background, the position of EaP migrants within the Italian labour market and in society at large, is hindered by the following features which characterise their current presence in Italy marked by their employment in the care and domestic sector:

- The disproportionate presence of women (with a partial exception in the Moldovan case) with a temporary migratory project, working in a very isolated environment and with scarce motivation (and opportunities) for socio-economic mobility and cultural or political participation in the Italian context.

- Their channelling into labour sectors predominantly perceived as "jobs for foreigners". These are jobs, like domestic work, characterised by a lack of social network (especially with trade unions) and opportunities for career and

\footnotetext{
39 Data updated on the $28^{\text {th }}$ of February by the Ministry of Interiors (see Ministero dell'Interno 2011a and 2011b).
} 
training. This places them in a troubling position within the Italian economy and society, hampering, once again, their social mobility.

- Their involvement in irregular employment and the informal economy which might go against rights acquisition, at the social and political level, i.e. access to citizenship and to social security.

\subsection{Recommendations}

As a consequence of the critical issues pointed out here, several experts highlight the need for changes in the legal framework on migration (see ISMU, 2011; EMN, 2010), which was put together when mass migration was just beginning.

Possible changes in the framework on labour migration law would improve the conditions of EaP migrants in Italy. For example:

1. changing the selection and hiring procedures, by introducing the "sponsor system" and by allowing entrance into the country for job seeking. Similarly, a reconfiguration of the quota-system will be needed in order to better adjust the determination of quotas to the actual needs of the Italian economy. This would reduce irregular migration and facilitate the match between supply and demand, especially in the domestic and care sector.

2. supporting temporary and circular forms of migration by making the application procedure easier and by facilitating the granting of permits for those who plan to work for short periods of time in Italy (e.g. Ukrainian women). This would mean strengthening the policies on return migration, especially bilateral arrangements on pension portability which is very relevant to EaP migrant domestic and care workers.

3. sustaining the process of integration into the Italian labour market for those who have more permanent migratory projects (e.g. Moldovan men and women). This should be done by enhancing their opportunities to train and for career mobility. An emphasis on their labour opportunities would, in turn, increase their chances of political and social integration.

4. from an EU perspective, promoting the uptake of bilateral agreements between Italy and other EaP countries - as the one already in place with Moldova. Likewise, the EU should also foster the implementation of integration measure, in line with the Global Approach on Migration and Mobility.

In conclusion, a new approach on labour migration would bring improvements for the labour conditions and the social integration of migrants from EaP countries. The irregularity which affects their arrival and settlement in the country would be effectively reduced. At the same time their contribution to Italian society and economy would be more visible and therefore, one would assume, better acknowledged. 


\subsection{Conclusion}

"Control" and "integration" seem to be the key terms of the most recent measures, in the field of migration policies, when we look at the current Italian and European frameworks. Yet, this section emphasised the need to rethink the labour dimension of migration policies.

With this in mind, the section analysed the most critical issues within labour migration as it is presently regulated, by taking working migrants in general and also, more specifically, migrant domestic and care workers who, as it was said, are conspicuous amongst EaP nationals in Italy. The allocation of quotas on the basis of the employment sector and nationality does not seem to fulfil the actual needs of the Italian labour market.

Finally, several possible ways to change this framework have been suggested, inviting more flexible devices and, in general, suggesting an increase in the number of permits which are granted to labour migrants. 


\section{General conclusions}

After having described the main features of migration from EaP countries to Italy, we can now draw some more general conclusions, assessing the forces which shape migrants' lives in Italy and suggesting some hypotheses on the strategies of adaptation played out by EaP nationals.

First, we have shown that the more recent Italian migration frameworks have implemented EU policies (i.e. Global approach on migration, Stockholm protocol, Return directive, etc.). These are at the background of Italian reforms such as the Bossi-Fini law (2002) and the Security Package (2009). Yet these frameworks do not seem to fulfil employers' demands for low-skilled workforce, leaving a good deal of room for unregulated employment.

EaP migrants, especially the female component, are mainly employed in the private home-based service sector meeting the demand for jobs such as private cleaners, babysitters and, above all, home-based caregivers due to the lack of a public system of long-term care provision. In the view of policy makers, this need will also be answered through the quota system. Yet, the workers who are currently active in this sector have come to it in an irregular fashion and only later have they regularised their position.

The modalities of recruitment and employment of migrants need to be understood in connection with the characteristics of the Italian labour market in comparison with other countries. These have to do with:

- A high incidence of unemployment, under-employment and brain waste, especially for women and the young;

- A significant informal economy, day-labour and "selling of labour" especially in the south;

- Difficult access to credit for buying houses and start-up new business, which leaves little space for entrepreneurial and self-employment outcomes;

- Strong regional asymmetries between northern and southern Italy in economic structure and social reality.

These issues are strongly related to scarce welfare provision for low income families and lengthiness in bureaucratic applications and court cases. These features are constitutive of the Italian economy and determine, with regard to national labour force, internal labour migration, the low labour participation of women, the emigration of highly-educated younger Italians and the lack of opportunities for business and investment.

As to migrants' conditions, it is important to take into consideration Italian political, cultural and social attitudes towards foreign nationals which determine the possibility of settling in the country. Structural features of the Italian public system are obstacles to the permanent settlement of foreign nationals and their families, such as: 
- scarce opportunities for upward mobility of migrants and their children;

- lack of a multicultural education system;

- long periods in the procedures for applying for citizenship, reunification, renewal residence permits.

Given the above structural setting for migration and general policies (welfare, labour, social integration) in Italy, the different groups from EaP countries find different positions concerning labour, geographical location, access to family and individual rights, etc.

In fact, on the basis of the demographic features of EaP nationals in Italy (age, gender composition, family status), and thanks to a first analysis of the most common paths within their group two prevailing models of migration prevail: a more permanent migration model by Moldovans and a more temporary migration model by Ukrainians, and likely by Georgians and Belarusians.

The two prevailing migration patterns show the adaptation of the two main groups to the opportunities offered by the country. The more residential and permanent migrants, the Moldovans, who follow the Romanian model of integration with a very high chance of success, and the Ukrainians with their more temporary model of migration which maximises their savings.

While both groups contribute to Italian welfare and economic growth, what is less clear is the effect of these migratory models on the migrants' wellbeing, both as they go back home and as they remain in the destination country. This is affected at home especially, by the limited possibility of getting a pension, and, in Italy, by the difficulty in getting a highly-skilled job.

It is in this perspective, that measures on these issues are suggested in the recommendations for the policies that, both at the national and the European level, could effectively improve the condition of EaP migrants in Italy. 


\section{References}

ACLI-COLF and IREF 2011. "Cosa penso di voi". Le opinioni e la condizione delle colf in Italia. Roma: Acli.

AMBROSINI, M. and BECCALLI, B. 2009. Uomini in lavori da donne: il lavoro domestico maschile. In: R. CATANZARO and A. COLOMBO (eds). Badanti and Co. Il lavoro domestico straniero in Italia. Bologna: Il Mulino.

AMMATURO, N., FILIPPO, E. D. and STROZZA, S. (eds.) 2010. La vita degli immigrati a Napoli e nei paesi vesuviani. Un’indagine empirica sull'integrazione. Milano: FrancoAngeli.

BADURASHVILI, I. 2004. Determinants and consequences of irregular migration in a society under transition. The case of Georgia, Caucasus. Georgian Centre of Population Research.

BARONE, G. and MOCETTI, S. 2010. With a little help from abroad: the effect of low-skilled immigration on the female labor supply. Temi di Discussione n. 766. Roma: Banca d'Italia.

BASCHERINI, G. and NICCOLARI, S. 2010. Regolarizzare Mary Poppins. Lavoro nello spazio domestico e qualità della cittadinanza. Rivista del diritto della sicurezza sociale, 3 (special issue).

BENTIVOGLI, F., CARFAGNA, M. and PITTAU, F. 2004. L'incidenza dell'Est Europa in Italia dopo la regolarizzazione del 2002. In: OLIVIERI, F., PITTAU, F. and A. RICCI (eds). Europa. Allargamento a Est e immigrazione. Roma: Idos.

BOCALE, P. and MANZI, G. 2010. La migrazione dall'Ucraina in Italia: un confronto tra dati statistici ucraini e italiani. Available online at: http://www.neodemos.it/index.php?file=onenews\&form_id_notizia $=393$ [Accessed on 15/04/2012]

BOBROVA, N. (forthcoming, 2012). The Socio-political Impact of Labour Migration in Belarus. CARIM-East Working Paper series. European University Institute.

BOBROVA, N., and SHAKHOTSKA, L. (forthcoming, 2012). The impact of labour migration in Belarus: the demographic and economic perspective. CARIM-East Working Paper series. European University Institute.

BRUECKER, H. et al. 2010. Labour mobility within the EU in the context of enlargement and the functioning of the transnational arrangements. European Integration Consortium.

BRUECKER, H., FACCHIN, S. and VENTURINI, A. 2011. Do foreigners replace natives immigrants? Evidence from a panel cointegration analysis. Economic Modelling, Elsevier, vol. 28(3), pp. 1078-1089.

CARITAS/MIGRANTES 2010. Dossier statistico immigrazione 2010. XX Rapporto. Roma: Idos.

CARITAS/MIGRANTES 2011. Dossier statistico immigrazione 2011. XXI Rapporto. 
Roma: Idos.

CASTAGNONE, E.andPASTORE, F. 2012. Migrant domestic work in Italy. Background overview. Fieri, Research Workshop for the EIF project "Promoting the integration of MDWs in Europe” ILO, Geneva, 17-18 January 2012.

CEDEFOP 2012. Skill labour demand in Europe. European Commission.

CENSIS 2010. Dare casa alla sicurezza. Rischi e prevenzione per i lavoratori domestici. Roma: CENSIS.

CESAREO, V. and BLANGIARDO, G.C. (eds.) 2001. Integration Indexes. An empirical research on migration in Italy. Milano: ISMU.

CESAREO, V. and BLANGIARDO, G.C. 2009. Indici di integrazione, Un'indagine empirica sulla realtà migratoria italiana. Fondazione ISMU. Milano: FrancoAngeli.

CESARINI, E. 2011. Programmazione delle quote e procedure: analisi ed elementi di criticità. Second EMN National Conference. Rome

CHOBANYAN, H. 2012. On the Migration Policy Framework in the Republic of Armenia. Explanatory Note 12/03, Socio-political Module. CARIM-East. European University Institute

CHOBANYAN A and V. GEVORGYAN (forthcoming, 2012). The Socio-political Impact of Labour Migration in Armenia. CARIM-East Working Paper series. European University Institute.

CICERCHIA, M. and PALLARA, P. (eds.) 2009. Gli immigrati nell'agricoltura italiana. Roma: INEA.

CNEL and CARITAS/MIGRANTES 2010. Indici di integrazione degli immigrati in Italia. Il potenziale di integrazione nei territori italiani. Analisi dell'occupazione e della criminalità per collettività. VII Rapporto. Roma: CNEL.

COUNCIL OF EUROPE 2008. Joint Declaration on a mobility partnerships between the European Union and the Republic of Moldova.

COUNCIL OF EUROPE 2009. Joint Declaration on a mobility partnership between the European Union and Georgia.

COUNCIL OF EUROPE 2009. Joint Declaration on a mobility partnership between the European Union and Georgia. Annex.

COUNCIL OF EUROPE 2009. Conclusions on Mobility Partnerships as a tool of the Global Approach to Migration.

DAMURI, F. and PINOTTI, P. 2010. Immigration and natives' labor market outcomes: evidence from Italy. Rome: Bank of Italy - Mimeo.

DE FILIPPO, E. and STROZZA, S. 2011. Le migrazioni interne degli stranieri in Italia. Milano: FrancoAngeli. 
DEL BOCA, D. and VENTURINI, A. 2005. Italian Migration. In: ZIMMERMANN, K. (ed), European migration. Oxford: Oxford UP.

DELL'ARRINGA, C. and PAGANI, L. 2011. Labour market assimilation and overEducation: The case of immigrant workers in Italy. Economia Politica, vol. 2, pp. 219-240.

DEMAIO, G. and GIOVANNINI, M. 2011. I lavoratori domestici immigrati tra irregolarità e sommerso. In: INPS and IDOS 2011. IV Rapporto sui lavoratori di origine immigrata negli archivi INPS. La regolarità del lavoro come fattore di integrazione. Roma: Idos.

DE VILLANOVA, C. 2009. I costi della migrazione per la finanza pubblica. In: ISMU, Quindicesimo rapporto sulle migrazioni. Milano: FrancoAngeli.

EFENDIYEV, R. (forthcoming, 2012). Brain drain as a global phenomenon and its specificities for Azerbaijan. CARIM-East Working Paper series. European University Institute.

EINAUDI, L. 2011. Alcuni aspetti economici dell'immigrazione di lungo periodo in Italia. Second EMN National Conference. Rome, 9th of November 2011.

EINAUDI, L. 2007. Le politiche dell'immigrazione in Italia dall'Unità a oggi. Bari: Laterza.

EMN 2010. Labour market and migration. Third EMN Italy report. Roma: Idos.

EMN 2010. Satisfying labour demand through migration. The Italian case. Roma: Idos.

EMN 2010. Temporary and circular migration: Empirical evidence, current policy practice and future options in Italy. Roma: Idos.

EMN 2011. Migration channels: Visa and irregular flows. Fourth EMN Italy report. Roma: Idos.

EMN 2012. Visa policy as migration channel in Italy. Roma: Idos

ESPING-ANDERSEN, G. 1990. The three worlds of welfare capitalism. Cambridge: Polity Press.

ETF 2010. Black Sea Labour Market Reviews, Georgia country report, ENPI8-14.

ETF 2009. Black Sea Labour Market Reviews, Moldova country report, ENPI8-14.

ETF 2011. Labour markets and Employability Trends and Challenges in Armenia, Azerbaijan, Belarus, Georgia, Moldova and Ukraine: Luxembourg: EU office.

ETF 2009. Black Sea Labour Market Reviews, Ukraine country report, ENPI8-14.

ETF 2010. Black Sea Labour Market Reviews, Azerbaijan country report, ENPI814 .

ETF 2010. Black Sea Labour Market Reviews, Belarus country report, ENPI8-14.

ETF 2010. Black Sea Labour Market Reviews, Armenia country report, ENPI8-14. 
EU-MIDIS 2010. European Union Minorities and Discrimination Survey. Data in Focus Report Multiple Discrimination. European Union Agency for Fundamental Rights.

FAINI, R., S. STROM, A. VENTURINI and C. VILLOSIO (2009). Are foreign migrants more assimilated than native ones?. IZA Discussion paper n. 4639. Bonn: IZA.

FASANI, F. 2008. Undocumented migration. Counting the uncountable. Data and Trends across Europe. Country report Italy, CLANDESTINO. Available on line http://irregular-migration.net/typo3upload/groups/31/4.[Accessed on 15/04/2012]

FEDYUK, O. 2011. Ukrainian migration to the EU: Character and impact in the context of changing EU legality regimes and policies. IMISCOE Eight Annual Conference. Warsaw, $8^{\text {th }}-10^{\text {th }}$ September 2011.

FERRERA, M. and RHODES, M. 2000. Recasting European welfare states. London: Frank Cass.

FULLIN, G. and REYNERI, E. 2011. Low unemployment and bad jobs for new immigrants in Italy. International Migration, vol. 49, n. 1, pp. 118-147.

GALLOTTI, M. 2009. The gendered dimension of domestic work. International Migration Papers. Geneva: ILO.

GANTA, V. (forthcoming, 2012). The impact of labour migration on the demographic and economic situation of Moldova. CARIM-East Working Paper series. European University Institute

GAVOSTO, A., VENTURINI,A. and VILLOSIO, C. 1999. Do immigrants compete with natives? Labour, n. 3, vol. 13, pp. 603-622.

HUDDLESTON, T. et al. 2011. Migrant integration policy index. London: British Council and MPG.

ILO 2009. Migration and development. Armenia country study. Yerevan: International Labour Organisation.

INPS and IDOS 2011. IV Rapporto sui lavoratori di origine immigrata negli archivi INPS. La regolarità del lavoro come fattore di integrazione. Roma: Idos.

INPS and IDOS 2009. III Rapporto su immigrati e previdenza negli archivi INPS. Diversità culturale, identità di tutela. Roma: Idos.

IOM 2008a. Migration to Moldova. A country profile. IOM: Geneva.

IOM 2008b. Migration in the Black Sea Region: An Overview. IOM: Geneva.

ISMU 2010. Quindicesimo rapporto sulle migrazioni 2009. Milano: FrancoAngeli.

ISMU 2011. Sedicesimo rapporto sulle migrazioni 2010. Milano: FrancoAngeli.

ISMU 2011b. Decimo rapporto sugli immigrati in Lombardia. Anno 2010. Milano: Regione Lombardia. 
ISMU, 2012. Diciassettesimo rapporto sulle migrazioni 2011. Milano: FrancoAngeli.

ISTAT 2004. Permessi di regolarizzazione concessi in base alle leggi n. 189/2002 e n. 222/2002 per area geografica e principali paesi di cittadinanza, per sesso al $1^{\circ}$ gennaio 2004. Available online: http://demo.istat.it/altridati/permessi/index.html [Accessed on 12/04/2012]

ISTAT 2005. Classificazione dei titoli di studio italiani. Available online: http://www.istat.it/it/archivio/6620 [Accessed on 15/01/2012]

ISTAT 2006. L’interruzione volontaria di gravidanza in Italia. Roma: Istat.

ISTAT 2008. Salute e ricorso ai servizi sanitari della popolazione straniera residente in Italia. Roma: Istat.

ISTAT 2010. La misura dell'economia sommersa secondo le statistiche ufficiali. Roma: Istat.

IVACHENKO, E. (forthcoming, 2011). The Socio-Political Consequences Impact of Labour Migration in Ukraine: A Reflection based on Sociological Analysis. CARIMEast Working Paper series. European University Institute.

KUPETS O. 2012. The Development and the Side Effects of Remittances in the CIS Countries: the Case of Ukraine. CARIM-East Research Report 2012/o2. European University Institute

LEONČIKAS, T. and ŽIBAS, K. 2009. Migration trends 20o6-20o8. Söderköping process countries. Kyiv: Söderköping Process Secretariat.

MARCHETTI, S. and VENTURINI, A. (forthcoming). Mothers and grandmothers on the move. Labour mobility and the household strategies of Moldovan and Ukrainian migrant women in Italy. International migration.

MESINI, D., PASQUINELLI, S. and RUSMINI, G. 2006. Il lavoro privato di cura in Lombardia. Caratteristiche $e$ tendenze in materia di qualificazione $e$ regolarizzazione. Milano: IRS.

MINISTERO DEL LAVORO 2011. L’immigrazione per lavoro in Itala: evoluzione e prospettive. ItaliaLavoro.

MINISTERO DELL'INTERNO 2007. Rapporto sulla criminalità in Italia. Analisi, prevenzione e contrasto. Roma

MINISTERO DELL'INTERNO 2010. Colf e badanti, $i$ dati riepilogativi al 5 luglio. Available online:

http://www.interno.it/mininterno/export/sites/default/it/sezioni/sala_stampa/n otizie/immigrazione/oo76_2010_07_12_colf_badanti.html [Accessed on 12/04/2012]

MINISTERO DELL'INTERNO 2011a. Decreto flussi 201. Andamento domande pervenute aggiornato al 28 febbraio 2011. Available online: http://www.interno.it/mininterno/export/sites/default/it/assets/files/20/o255_ Distribuzione_Domande_Pervenute_-_Click_Day_-_DCP.pdf 
MINISTERO DELL'INTERNO 2011b. Stagionali 2010. Situazione domande pervenute, aggiornato al 26 aprile 2010. Available online: http://www.interno.it/mininterno/export/sites/default/it/assets/files/19/o78o_S tagionali_2010_-_Aggiornamento.pdf

MOCETTI, S. and PORELLO, C. 2010. How does immigration affect native internal mobility? New evidence from Italy. Temi di Discussione. Roma: Banca d'Italia.

MOSNEAGA, V. (forthcoming, 2011). The Socio-political Impact of Labour Migration in Moldova.CARIM-East Working Paper series. European University Institute.

MSF 2005. I frutti dell'ipocrisia. Storia di chi l'agricoltura la fa. Di nascosto. Indagine sulle condizioni di vita e di salute dei lavoratori impiegati nei campi del Sud Italia. Available online: http://www.medicisenzafrontiere.it/Immagini/file/pubblicazioni/RAPPORTO_fr utti_ipocrisia.pdf. Accessed on [8/02/2012]

NANNI, M. 2010. 2009: una regolarizzazione "selettiva" In: CARITAS/MIGRANTES. Immigrazione. Dossier statistico 2010. XX Rapporto. Roma, Idos.

NANNI, M. and FUCILITTI, A. 2011. Welfare, spesa sociale e immigrazione. Un quadro d'insieme. In: INPS and IDOS 2011. IV Rapporto sui lavoratori di origine immigrata negli archivi INPS. La regolarità del lavoro come fattore di integrazione. Roma: Idos.

OECD 2010. International migration outlook. Paris: SOPEMI.

OECD 2012. Factbook 2011-2012. Economic, Environmental and Social Statistics. Geneva: OECD.

OPRUNENKO, A. 2012. National Strategy for Migration and Asylum: an Attempt of Holistic and Integrated Approach towards Migration Issues in Moldova. Explanatory Note 12/10, Socio-political Module. CARIM-East. European University Institute.

PAGGIARO, A. 2011. The effect of economic downturns of the career of immigrants. Journal of population economics, forthcoming http://www.csea.decon.unipd.it/download/projects/immigration/CSEA_2011_o o3_Paggiaro.pdf

PASQUINELLI, S. 2012. Badanti: dilaga il lavoro nero. Available online: http://www.qualificare.info/home.php?id=585 [Accessed 30/01/2012].

PASQUINELLI, S. and RUSMINI, G. 2008. Badanti: la nuova generazione. Caratteristiche e tendenze del lavoro privato di cura. Milano: IRS.

PASTORE, F. and VILLOSIO, C. 2011. Nevertheless attracting...Italy and Immigration in times of crisis. Working papers n. 106, LABORatorio R. Revelli. Torino: Centre for Employment Studies.

PELLIZZARI, M. 2011. The use of welfare by migrants in Italy. IZA Discussion 
Paper n. 5613. Bonn: IZA.

PIAZZALUNGA, D. 2011, Un doppio svantaggio? Differenziali salariali sulla base del genere e dell'etnia.Working Paper6/2011. Torino: Dipartimento di economia "Cognetti de Martiis".

POZNYAK O. (forthcoming, 2012). External labour migration in Ukraine as a factor of social, demographic and economic development.CARIM-East Working Paper series. European University Institute.

PRIBYTKOVA, I. and GROMOVS, J. 2007. Migration trends 2004-2006. Söderköping process countries. ILO-EC.

ROMITI, A. 2011. Immigrants-natives complementarities in production: evidence from Italy. CeRP Working papers. CeRP.

ROMITI, A. and ROSSI, M. 2011. Should we retire earlier in order to look after our parents? The role of immigrants. CeRP Working papers. CeRP.

RUMYANSEV, S. (forthcoming, 2011). Labour Migration and Social Inequality in Post-Soviet Azerbaijan. CARIM-East Working Paper series. European University Institute.

RUWANPURA, K. N. 2008. Multiple Identities, Multiple-Discrimination: a Critical Review. Feminist Economics, vol. 14, n. 3, pp. 77-105.

SACCHETTO, D. (ed.) 2011. Ai margini dell'Unione Europea. Spostamenti e insediamenti a Oriente. Roma: Carocci.

SARTI, R. 2011. Lavoro domestico e di cura: quali diritti? Roma: Ediesse.

SARTI, R. and SCRINZI, F. (eds) 2010. Men in a Woman's Job, Male Domestic Workers, International Migration and the Globalization of Care.Men and Masculinities, vol. 13, n. 1 (special issue).

SPINELLI, B. 2011. Lavori in corsa. 30 anni Cedaw. Rapporto ombra. Roma: Pangea Onlus.

STAFFOLANI, S. and VALENTINI, E. 2009. Does Immigration Raise Blue and White Collar Wages of Natives?Working Papers 330. Università Politecnica delle Marche (I), Dipartimento di Scienze Economiche e Sociali.

STROZZA, S., GALLO, G. and GRILLO, F. 2003. Gender and the labour market among immigrants in some Italian areas: the case of Moroccans, former Yugoslavians and Poles. In: GARCIA, B., R. ANKER and A. PINNELLI (eds.), Women in the labour market in changing economies: demographic issues. Oxford: Oxford UP.

TOGNETTI BORDOGNA, M. 2011. Le badanti: accesso e uso del welfare sanitario per sé e per il badato. In: T. CAPONIO, F. GIORDANO, B. MANETTI and L. RICALDONE (eds). World wide women, Globalizzazione, generi, linguaggi. Volume 3. Torino: CIRSDe. 
TOLSTOKOROVA, A. 2009. Costs and Benefits ofLabour Migration for Ukrainian Transnational Families: Connection or Consumption? In: Lescahiers de l'URMIS. Circulation migratoire et insertions économiques précaires en Europe, n. 12, juin, 2009. Available online at: http://urmis.revues.org/index868.html.

TRANSATLANTIC TRENDS2011. Transatlantic Trends: Immigration. Key findings 2011. German Marshall Fund of the United States, Bradley Foundation, Compagnia di San Paolo, Barrow Cadbury Trust.

UNAR 2011. Relazione al parlamento sull'effettiva applicazione del principio di parità di trattamento e sull'efficacia dei meccanismi di tutela. Anno 2011. Presidenza del Consiglio dei Ministri. Dipartimento per le Pari Opportunità

UNDP 2009. National human development report 2009. Migration and human development: Opportunities and challenges. Armenia: UNDP.

VENTURINI, A. 1999. Do immigrants working illegally reduce the natives' legal employment? Evidence from Italy. Journal of Population Economics, vol. 12, n. 1, pp. 135-154.

VENTURINI, A. 2001. Le migrazioni e i paesi sudeuropei. Un'analisi economica. Torino: UTET.

VENTURINI, A. 2004. Post-war migration in Southern Europe. An economic approach. Cambridge: Cambridge UP.

VENTURINI, A. and VILLOSIO, C. 2006. Labour market effects of immigration into Italy: An empirical analysis. International Labour Review, vol. 145, n. 1-2, pp. 91-118.

VENTURINI, A. and VILLOSIO, C. 2008. Assimilation of migrants in recent immigration countries: The Italian experience. $O X R E P$, vol. 24, n. 3, pp. 518-542.

VIANELLO, F. A. 2009. Migrando sole. Legami transnazionali tra Ucraina $e$ Italia. Milano: FrancoAngeli.

VIETTI, F. 2010. Il paese delle badanti. Roma: Meltemi.

VILLOSIO, C. and BIZZOTTO, G. 2011. Once there were wives and daughters, now there are badanti. Work in home elderly care in Italy is still an informal, unqualified and unrecognised occupation. Walqing social partnership series.

YEGANYAN, R. 2012. Impact of labour migration on demographic development of Armenia. CARIM-East Working Paper series. European University Institute.

ZANFRINI, L. 2012. Il lavoro. In: ISMU. Diciassettesimo rapporto sulle migrazioni 2011. Milano: FrancoAngeli.

ZURABISHVILI, T. 2012. Dynamics of remittances in Georgia. Explanatory Note 12/o8, Socio-political Module. CARIM-East. European University Institute. 


\section{Annex I - Datasets}

\begin{tabular}{|c|c|}
\hline $\begin{array}{l}\text { Foreign-born and } \\
\text { foreign population }\end{array}$ & $\begin{array}{l}\text { For the difference between foreign-born and foreign population see OECD (2010). For } \\
\text { EaP countries we refer to foreign population. }\end{array}$ \\
\hline Census & $\begin{array}{l}\text { No individual data available. } \\
\text { Each } 10 \text { years: last one in 2011, but no data available yet; previous one in 2001, data } \\
\text { available at http://dawinci.istat.it/ (Italian only). } \\
\text { Main information: citizenship, age, gender, civil status, education, sectors of } \\
\text { employment (agriculture, industry, services etc), labour force and employment rate, } \\
\text { waged labour versus self-employment, reason for residence permits. }\end{array}$ \\
\hline Residence permits & $\begin{array}{l}\text { No individual data available. } \\
\text { Annual data. } \\
\text { Released by the Home Office, which overstated foreign population until } 1992 \text { (expired } \\
\text { permits were included). } \\
\text { Elaborated by Istat from 1991, by removing the expired permits. } \\
\text { Minors registered in the permits of their parents, estimation of their numbers only from } \\
2008 . \\
\text { Since } 2008 \text { (European Directive } 2004 / 38 / \mathrm{CE} \text { ) individuals from the European Union } \\
\text { and their family members then not registered in the residence permits data. } \\
\text { Variables for all countries: gender. } \\
\text { Variables for the main regions of origin and some major countries: reason for permit, } \\
\text { age structure, marital status, years since migration. Total immigrants in region and } \\
\text { provinces by sex, age, reasons, marital status. } \\
\text { Available at dati.istat.it; } \\
\text { http://demo.istat.it/altridati/permessi/ (Italian only); } \\
\text { http://demo.istat.it/altridati/noncomunitari/index.html (Italian only). }\end{array}$ \\
\hline $\begin{array}{l}\text { Population } \\
\text { registers }\end{array}$ & $\begin{array}{l}\text { No individual data available. } \\
\text { Annual data released by Istat (available at http://dati.istat.it). } \\
\text { Underestimates the number of immigrants, especially for small groups. } \\
\text { Variables: gender, regional distribution; age only for immigrants as a whole. }\end{array}$ \\
\hline $\begin{array}{l}\text { Labour Force } \\
\text { Survey }\end{array}$ & $\begin{array}{l}\text { Individual data available at http://www.istat.it/en/archive/36394. } \\
\text { Released by Istat every quarter. } \\
\text { Sample survey (about 170,ooo individuals every quarter). } \\
\text { Risk of underrepresentation of small groups. } \\
\text { Reference population all household members officially resident in Italy (from } \\
\text { population registers): illegal, seasonal and unregistered immigrants not included; co- } \\
\text { resident workers (e.g. most women care workers) not sampled. } \\
\text { Variables: demographic characteristics as gender, age, territory (up to regional detail), } \\
\text { marital status, citizenship, years since migration, education; labour market outcomes } \\
\text { (employment status, type of work, work experience, job search, legal wages, etc.). For a } \\
\text { comprehensive list of all variables see the metadata on site. } \\
\text { Second quarter of } 2008 \text { survey includes specific questions for foreign people (parents' } \\
\text { citizenship, recognition of foreign qualification, use of dedicated services, language } \\
\text { spoken, permits' reason etc.). } \\
\text { European LFS cover all the European countries, and in addition Iceland, Norway and } \\
\text { Switzerland. Individual data available upon request for research purposes, see } \\
\text { http://epp.eurostat.ec.europa.eu/portal/page/portal/microdata/lfs. }\end{array}$ \\
\hline $\begin{array}{l}\text { Italian EU-SILC on } \\
\text { foreign people }\end{array}$ & $\begin{array}{l}\text { At the moment unique sample survey "Income and living conditions" on 6,000 } \\
\text { households with at least one foreign member (15,000 individuals) (2009). } \\
\text { Individual data available upon request, see http://www.istat.it/it/archivio/52405, }\end{array}$ \\
\hline
\end{tabular}




\begin{tabular}{|c|c|}
\hline & $\begin{array}{l}\text { Italian only. } \\
\text { Same methodological tools as the EU-SILC, then comparable with the survey for Italian } \\
\text { people. } \\
\text { Variables: gender, age, marital status, origin and citizenship (only main countries of } \\
\text { immigration; smaller groups divided into other European or non European countries), } \\
\text { years since migration, education, main reasons for coming to Italy, type of residence } \\
\text { permits, health, socio-economic information (house, durable goods, expenditures, rent, } \\
\text { loans, social benefits), labour market outcomes (employment status, type of work, work } \\
\text { experience, job search, income, etc.). }\end{array}$ \\
\hline $\begin{array}{l}\text { Labour Social } \\
\text { Security Data } \\
\text { (Inps) }\end{array}$ & 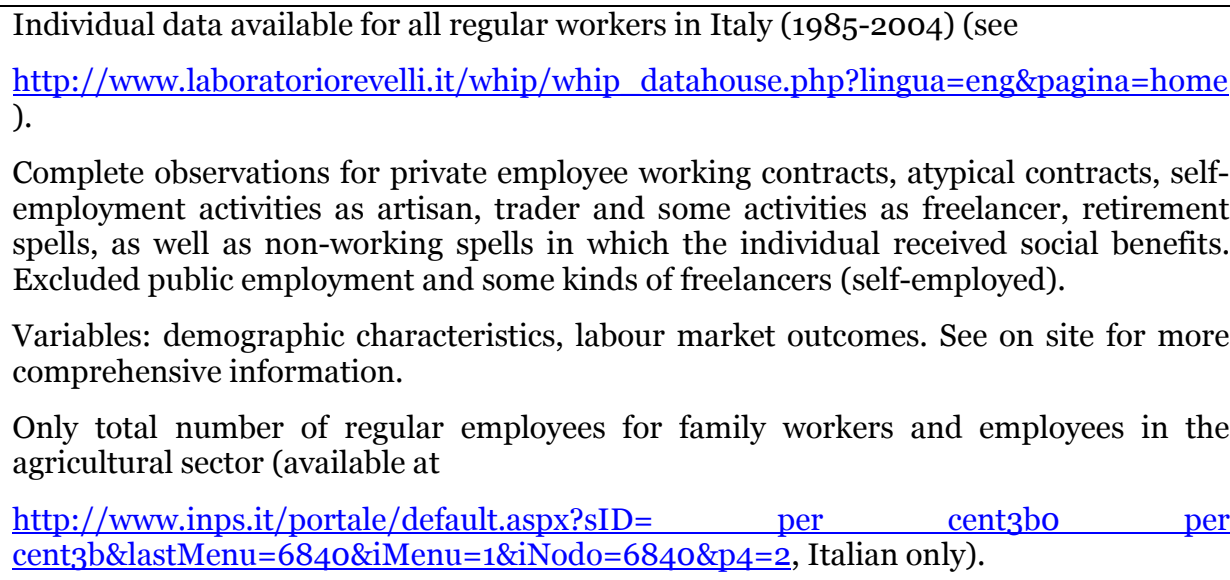 \\
\hline $\begin{array}{l}\text { Workers } \\
\text { Compensation } \\
\text { Authority (Inail) }\end{array}$ & $\begin{array}{l}\text { No individual data. } \\
\text { Annual data on accidents at work. } \\
\text { Available at } \\
\text { http://www.inail.it/Portale/appmanager/portale/desktop? nfpb=true\& pageLabel=P } \\
\text { AGE_STATISTICHE) }\end{array}$ \\
\hline $\begin{array}{l}\text { Bank of Italy - } \\
\text { Household Income } \\
\text { and Wealth }\end{array}$ & $\begin{array}{l}\text { Individual data available at http://www.bancaditalia.it/statistiche/indcamp/bilfait. } \\
\text { Sample survey (about 24,ooo individuals) done every } 2 \text { years (last one 2010). } \\
\text { Demographic characteristic (age, gender, citizenship only by main area of origin, etc.) } \\
\text { and detailed information on income, expenditure and savings, wealth. }\end{array}$ \\
\hline $\begin{array}{l}\text { Italian Association } \\
\text { of the Chambers of } \\
\text { Commerce } \\
\text { (Unioncamere) - } \\
\text { Excelsior }\end{array}$ & $\begin{array}{l}\text { Annual data on labour market forecast (see http://excelsior.unioncamere.net/ ). } \\
\text { Information on the occupational needs of Italian enterprises. } \\
\text { Not included needs of Italian family (main employers for domestic and care jobs). } \\
\text { Occupational needs by type of work (included internships), sectors of employment, } \\
\text { education and trainings; difficulties and skill shortages at regional and provincial level, } \\
\text { including the maximum number of immigrants hired. }\end{array}$ \\
\hline ISMU Foundation & $\begin{array}{l}\text { Annual sample survey on immigrants in Lombardy(together with ORIM). } \\
\text { Individual data are private, available upon request (http://www.ismu.org/) } \\
\text { Variables: gender, age, marital status, religion, education, type of residence permits, } \\
\text { years since migration, living place, children (abroad or in Italy), employment status, } \\
\text { type of occupation, income, intention to move, intention for family reunion. } \\
\text { Italian people not included (no comparison possible). }\end{array}$ \\
\hline
\end{tabular}




\section{Annex II - Tables}

Tab. A.1 - First 20 countries 1992, 2011

\begin{tabular}{|c|c|c|c|c|c|c|c|}
\hline & \multicolumn{3}{|l|}{1992} & & \multicolumn{3}{|l|}{2011 (a) } \\
\hline & Countries & tot & $\begin{array}{l}\text { per cent } \\
\text { women }\end{array}$ & & Countries & tot & $\begin{array}{l}\text { per cent } \\
\text { women }\end{array}$ \\
\hline 1 & Morocco & 83,292 & 9.8 & 1 & Morocco & 501,610 & 41.9 \\
\hline 2 & Tunisia & 41,547 & 9.0 & 2 & Albania & 483,219 & 45.6 \\
\hline 3 & United States & 41,523 & $65 \cdot 3$ & 3 & China & 274,417 & 48.2 \\
\hline 4 & Philippines & 36,316 & 67.2 & 4 & Ukraine & 218,099 & 81.1 \\
\hline 5 & Germany & 26,377 & 58.2 & 5 & Moldova & 142,583 & 68.0 \\
\hline 6 & Yugoslavia & 25,848 & 37.0 & 6 & India & 142,565 & 34.7 \\
\hline 7 & Albania & 24,886 & 14.1 & 7 & Philippines & 136,597 & 58.7 \\
\hline 8 & Senegal & 24,194 & 2.9 & 8 & Tunisia & 116,651 & 34.7 \\
\hline 9 & Egypt & 18,473 & 14.2 & 9 & Egypt & 110,171 & 27.6 \\
\hline 10 & United Kingdom & 17,351 & 57.9 & 10 & Bangladesh & 103,285 & 27.9 \\
\hline 11 & France & 16,637 & 60.6 & 11 & Peru & 101,711 & 61.3 \\
\hline 12 & China & 15,776 & 39.8 & 12 & Serbia/ Kosovo/ Montenegro & 98,981 & 44.2 \\
\hline 13 & Switzerland & 15,007 & 55.1 & 13 & Senegal & 91,793 & 22.6 \\
\hline 14 & Poland & 12,139 & $55 \cdot 7$ & 14 & Pakistan & 90,222 & 30.0 \\
\hline 15 & Sri Lanka & 12,114 & 31.0 & 15 & Sri Lanka & 88,637 & 42.6 \\
\hline 16 & Ghana & 11,303 & 31.0 & 16 & Ecuador & 85,518 & 59.4 \\
\hline 17 & Brazil & 10,953 & 68.6 & 17 & Macedonia (FYROM) & 77,732 & 42.5 \\
\hline 18 & Spain & 10,863 & 64.2 & 18 & Nigeria & 58,404 & 53.0 \\
\hline 19 & India & 9,918 & 43.0 & 19 & Ghana & 52,914 & 41.2 \\
\hline \multirow[t]{2}{*}{20} & Argentina & 9,603 & 52.4 & 20 & Brazil & 46,422 & 72.3 \\
\hline & Total & 648,935 & 39.9 & & Total & $3,536,062$ & 48.4 \\
\hline \multirow{2}{*}{\multicolumn{2}{|c|}{$\begin{array}{l}\text { First } 20 \text { countries as a } \\
\text { percentage of total }\end{array}$}} & 72 per cent & & & & 85 per cent & \\
\hline & & & & & & & \\
\hline
\end{tabular}

Source: Istat, Residence permits (data from Home office)

Notes: (a) Since 2008 only non European citizens are included 
Tab. A.2 - Correspondence between Istat classification of levels of education and ISCED levels

\begin{tabular}{|c|c|c|c|}
\hline \multicolumn{2}{|l|}{ Italian classification } & \multirow{2}{*}{\begin{tabular}{|l|} 
ISCED 97 (Unesco)* \\
$\begin{array}{l}\text { Level o - Pre-primary } \\
\text { education }\end{array}$
\end{tabular}} & \multirow{3}{*}{$\begin{array}{l}\text { Low-middle-high } \\
\text { education }\end{array}$} \\
\hline $\begin{array}{l}\text { nessun titolo } \quad \mathrm{di} \\
\text { studio }\end{array}$ & No education & & \\
\hline licenza elementare & Primary education & $\begin{array}{l}\text { Level } 1 \text { - Primary education } \\
\text { or first stage of basic } \\
\text { education }\end{array}$ & \\
\hline licenza media & $\begin{array}{ll}\text { Lower } & \text { secondary } \\
\text { education } & \end{array}$ & $\begin{array}{l}\text { Level } 2 \text { - Lower secondary } \\
\text { or second stage of basic } \\
\text { education }\end{array}$ & $\begin{array}{l}\text { "Lower secondary education" } \\
\text { (ISCED 2) }\end{array}$ \\
\hline diploma 2-3 anni & $\begin{array}{l}\text { Upper } \\
\text { education }\end{array}$ & \multirow{2}{*}{$\begin{array}{l}\text { Level } 3 \text { - (Upper) secondary } \\
\text { education }\end{array}$} & \multirow{2}{*}{$\begin{array}{l}\text { "Upper secondary education" } \\
\text { (ISCED 3) }\end{array}$} \\
\hline diploma 4-5 anni & $\begin{array}{ll}\text { Upper } & \text { secondary } \\
\text { education } & 4-5 \text { years }\end{array}$ & & \\
\hline diploma belle arti & $\begin{array}{l}\text { Higher education in } \\
\text { humanities and arts }\end{array}$ & \multirow{6}{*}{$\begin{array}{l}\text { Level } 5 \text { - First stage of } \\
\text { tertiary education }\end{array}$} & \multirow{7}{*}{$\begin{array}{l}\text { "Tertiary education" (ISCED } \\
\text { 5-6) }\end{array}$} \\
\hline $\begin{array}{l}\text { diploma } \\
\text { parauniversitario }\end{array}$ & Higher education & & \\
\hline laurea 3 anni & Licence's degree (3 years) & & \\
\hline laurea 5 anni & Master's degree (5 years) & & \\
\hline laurea 5 anni v.o. & Master's degree (5 years) & & \\
\hline $\begin{array}{l}\text { specializzazione post } \\
\text { laurea }\end{array}$ & Post-graduate studies & & \\
\hline dottorato & $\mathrm{PhD}$ & $\begin{array}{l}\text { Level } 6 \text { - Second stage of } \\
\text { tertiary education }\end{array}$ & \\
\hline
\end{tabular}

See Istat (2005)

Tab. A.3 - Skill mismatch for immigrants from Belarus, by gender, 2011 Share of working age population (15-64)

\begin{tabular}{|c|c|c|c|c|c|c|c|}
\hline & & & \multicolumn{4}{|c|}{ Education } & \multirow[b]{2}{*}{ Tot } \\
\hline & Professions & Obs. & $\begin{array}{c}\text { Primary } \\
\text { and below }\end{array}$ & $\begin{array}{l}\text { Lower } \\
\text { second. }\end{array}$ & $\begin{array}{l}\text { Upper } \\
\text { second. }\end{array}$ & Tertiary & \\
\hline \multicolumn{8}{|c|}{ Belarus } \\
\hline \multirow[t]{3}{*}{ Female } & Unskilled & & 0.00 & 100.00 & $37 \cdot 32$ & 24.51 & 34.73 \\
\hline & Low skilled & & 100.00 & 0.00 & 62.68 & 75.49 & 65.27 \\
\hline & Total & 8 & 100.00 & 100.00 & 100.00 & 100.00 & 100.00 \\
\hline \multirow[t]{3}{*}{ Male } & Unskilled & & 0.00 & 0.00 & 100.00 & 0.00 & 44.23 \\
\hline & Low skilled & & 0.00 & 100.00 & 0.00 & 0.00 & 55.77 \\
\hline & Total & 2 & 0.00 & 100.00 & 100.00 & 0.00 & 100.00 \\
\hline \multirow[t]{3}{*}{ Total } & Unskilled & & 0.00 & 36.00 & 48.98 & 24.51 & 36.79 \\
\hline & Low skilled & & 100.00 & 64.00 & 51.02 & 75.49 & 63.21 \\
\hline & Total & 10 & 100.00 & 100.00 & 100.00 & 100.00 & 100.00 \\
\hline
\end{tabular}

Source: Istat LFS, 2011, second quarter 
Table A.4-A.7 are taken from the ISMU survey (2011b) on immigrants in Lombardy, 2010 with a special extraction for the project.

Tab. A.4 - Years since migration to Italy, by country of origin

Alb Rom Ukr SrL Chin Phil Ind Pak Egy Mor Sen Ecu Per Mold Lomb.

\begin{tabular}{llllllllllllllll}
\hline Less than 2 years & 4,4 & 5,5 & 7,7 & 3,1 & 12,1 & 9,8 & 10,3 & 12,6 & 6,2 & 4,4 & 9,4 & 4,1 & 8,2 & 8,4 & 6,7 \\
2-4 years & 11,1 & 20,4 & 11,8 & 9,9 & 18,7 & 23,7 & 18,6 & 12,4 & 10,6 & 13,2 & 15,5 & 7,9 & 12,7 & 17,9 & 14,3 \\
5-10 years & 46,9 & 55,7 & 71,6 & 62,4 & 45,5 & 25,9 & 47,3 & 45,7 & 44,1 & 43,1 & 37,0 & 56,6 & 45,3 & 64,5 & 47,0 \\
More than 10 years37,5 & 18,3 & 8,9 & 24,6 & 23,8 & 40,6 & 23,8 & 29,4 & 39,1 & 39,3 & 38,1 & 31,4 & 33,7 & 9,3 & 32,0 \\
\hline
\end{tabular}

Tab. A.5 - Type of accommodation and of contract, by country of origin

\begin{tabular}{|c|c|c|c|c|c|c|c|c|c|c|c|c|c|c|c|}
\hline & Alb & Rom & Ukr & SrL & Chin & Phil & Ind & Pak & Egy & Mor & Sen & Ecu & Per & Mold & Lomb. \\
\hline $\begin{array}{l}\text { Owned house } \text { (alone or } \\
\text { relatives) }\end{array}$ & with $_{24,6}$ & 17,3 & 9,6 & 16,4 & 23,9 & 20,6 & 26,0 & 31,7 & 24,3 & 19,0 & 19,2 & 34,1 & 29,3 & 13,5 & 23,2 \\
\hline $\begin{array}{l}\text { House with rent (alone or } \\
\text { relatives) with contract }\end{array}$ & with $_{61,0}$ & 50,7 & 35,1 & 57,3 & 41,9 & 46,7 & 45,2 & 42,2 & 43,7 & 58,5 & 43,4 & 50,4 & 47,0 & 35,8 & 49,3 \\
\hline $\begin{array}{l}\text { House with rent (alone or } \\
\text { relatives) without contract }\end{array}$ & with $_{1,0}$ & 3,5 & 3,0 & 9,8 & 4,5 & 8,1 & 2,9 & 2,8 & 4,1 & 2,8 & 2,4 & 3,6 & 3,8 & 3,1 & 3,3 \\
\hline $\begin{array}{l}\text { House with rent (alone or } \\
\text { relatives) Doesn't know }\end{array}$ & with $_{2,1}$ & 0,3 & 0,7 & 0,5 & 2,1 & 1,2 & 1,3 & 0,2 & 1,0 & 0,8 & 1,9 & 0,2 & 1,0 & 1,9 & 1,1 \\
\hline $\begin{array}{l}\text { Host at relatives', fri } \\
\text { acquaintances' (without paying }\end{array}$ & ends', 2,9 & 3,1 & 3,6 & 1,5 & 4,4 & 0,5 & 3,9 & 3,8 & 2,4 & 3,2 & 6,9 & 1,3 & 3,0 & 2,3 & 3,2 \\
\hline $\begin{array}{l}\text { House with rent (with } \\
\text { immigrants) with contract }\end{array}$ & other $_{4,5}$ & 8,3 & 5,1 & 5,1 & 3,5 & 5,5 & 6,0 & 12,0 & 13,6 & 6,9 & 15,2 & 3,7 & 1,7 & 8,9 & 7,5 \\
\hline $\begin{array}{l}\text { House with rent (with } \\
\text { immigrants) without contract }\end{array}$ & other $_{1,6}$ & 2,7 & 2,8 & 0,2 & 2,3 & 2,4 & 1,1 & 3,1 & 5,5 & 2,1 & 5,4 & 1,5 & 1,8 & 2,5 & 2,3 \\
\hline $\begin{array}{l}\text { House with rent (with } \\
\text { immigrants) Doesn't know }\end{array}$ & other $_{\mathrm{O}, 3}$ & 0,7 & 0,1 & 0,3 & 2,2 & 0,7 & 0,5 & 1,9 & 1,9 & 0,8 & 0,4 & 0,5 & 0,3 & 1,3 & 0,9 \\
\hline Hotel or pension (paying) & .. & 0,3 &.. &.. & .. & .. & .. & .. & 0,4 & 0,0 &.. &.. &.. &.. & 0,1 \\
\hline Host infrastructure & 0,2 & 1,7 & 0,7 & 1,7 & 1,6 & 1,3 & .. & .. & 0,9 & 1,7 & 1,0 & 0,4 & 0,2 & 0,7 & 1,3 \\
\hline On the workplace & 1,1 & 6,0 & 37,2 & 5,9 & 12,2 & 12,5 & 5,0 & 1,5 & 0,9 & 1,8 & 1,6 & 3,5 & 9,9 & 26,3 & 5,7 \\
\hline Squatting &.. & 0,3 &.. &.. &.. & .. & .. &.. & 1,0 & 0,3 & 0,9 & .. &.. & .. & 0,2 \\
\hline Concession free of charge & 0,6 & 0,8 & 2,1 & 1,4 & 1,4 & 0,4 & 7,3 & 0,7 & 0,2 & 1,3 & 1,0 & 0,6 & 1,9 & 3,6 & 1,3 \\
\hline Camps for nomads & 0,2 & 3,6 &.. &.. & .. & .. &.. & .. & .. & .. &.. & .. & $\cdot$. & .. & 0,4 \\
\hline Sheds o makeshift places &.. & 0,7 &.. &.. &.. &.. & 0,7 &.. & 0,0 & 0,8 & 0,7 & 0,2 &.. & .. & 0,3 \\
\hline
\end{tabular}

Total 100,0100,0100,0100,0100,0100,0100,0100,0100,0100,0100,0100,0100,0100,0 100,0


Tab. A.6 - Number of children of immigrants (total number), by country of origin

\begin{tabular}{|c|c|c|c|c|c|c|c|c|c|c|c|c|c|c|c|}
\hline & Alb & Rom & Ukr & $\mathrm{SrL}$ & Chin & Phil & Ind & Pak & Egy & Mor & Sen & Ecu & Per & Mold & Lomb. \\
\hline o & 42,2 & 38,9 & 29,0 & 40,9 & 38,7 & 40,4 & 34,7 & 42,5 & 42,1 & 45,1 & 35,4 & 38,3 & 40,0 & 33,5 & 41,0 \\
\hline 1 & 16,5 & 30,6 & 28,0 & 26,9 & 27,9 & 22,6 & 21,2 & 6,2 & 17,3 & 17,8 & 18,4 & 24,1 & 26,2 & 22,0 & 21,2 \\
\hline 2 & 31,8 & 19,7 & 39,1 & 25,2 & 23,6 & 24,7 & 35,1 & 17,3 & 20,2 & 19,5 & 22,1 & 23,6 & 16,9 & 34,1 & 23,7 \\
\hline 3 & 6,8 & 6,5 & 3,8 & 7,0 & 9,1 & 7,1 & 7,6 & 16,6 & 16,2 & 12,0 & 12,1 & 8,3 & 11,8 & 10,3 & 9,6 \\
\hline 4 or more & 2,8 & 4,3 & 0,2 & 0,0 & 0,6 & 5,2 & 1,4 & 17,3 & 4,3 & 5,6 & 12,1 & 5,7 & 5,1 & .. & 4,6 \\
\hline$\overline{\text { Total }}$ & $10 O, O$ & $10 O, O$ & 100,0 & 100,0 & $10 O, O$ & 100,0 & 100,0 & 100,0 & $10 O, O$ & $10 O, O$ & $10 O, O$ & 100,0 & 100,0 & 100,0 & $10 O, O$ \\
\hline
\end{tabular}

Tab. A.7: Number of children of immigrants (in Italy), by country of origin

\begin{tabular}{llllllllllllllll}
\hline & Alb & Rom & Ukr & SrL & Chin & Phil & Ind & Pak & Egy & Mor & Sen & Ecu & Per & Mold & Lomb. \\
\hline o & 46,0 & 53,7 & 76,4 & 54,4 & 55,7 & 67,6 & 45,5 & 57,6 & 57,0 & 53,0 & 66,5 & 50,3 & 58,6 & 73,1 & 55,8 \\
1 & 18,5 & 24,9 & 16,1 & 26,2 & 19,6 & 12,8 & 16,4 & 5,7 & 14,0 & 15,4 & 12,5 & 19,3 & 20,2 & 16,0 & 17,5 \\
2 & 28,7 & 13,6 & 7,1 & 13,8 & 17,9 & 14,3 & 30,2 & 12,2 & 14,9 & 17,7 & 12,4 & 22,7 & 11,8 & 10,2 & 17,4 \\
3 & 5,6 & 5,1 & 0,4 & 5,6 & 6,5 & 4,0 & 6,8 & 12,1 & 11,6 & 10,0 & 6,2 & 5,6 & 7,2 & 0,7 & 6,8 \\
4 & 1,2 & 2,7 & 0,0 & 0,0 & 0,3 & 1,3 & 1,1 & 12,4 & 2,6 & 3,9 & 2,5 & 2,0 & 2,2 &.. & 2,5 \\
\hline Total more & 100,0 & 100,0 & 100,0 & 100,0 & 100,0 & 100,0 & 100,0 & 100,0 & 100,0 & 100,0 & 100,0 & 100,0 & 100,0 & 100,0 & 100,0
\end{tabular}


Fig. A.8 - Integration indexes construction pattern

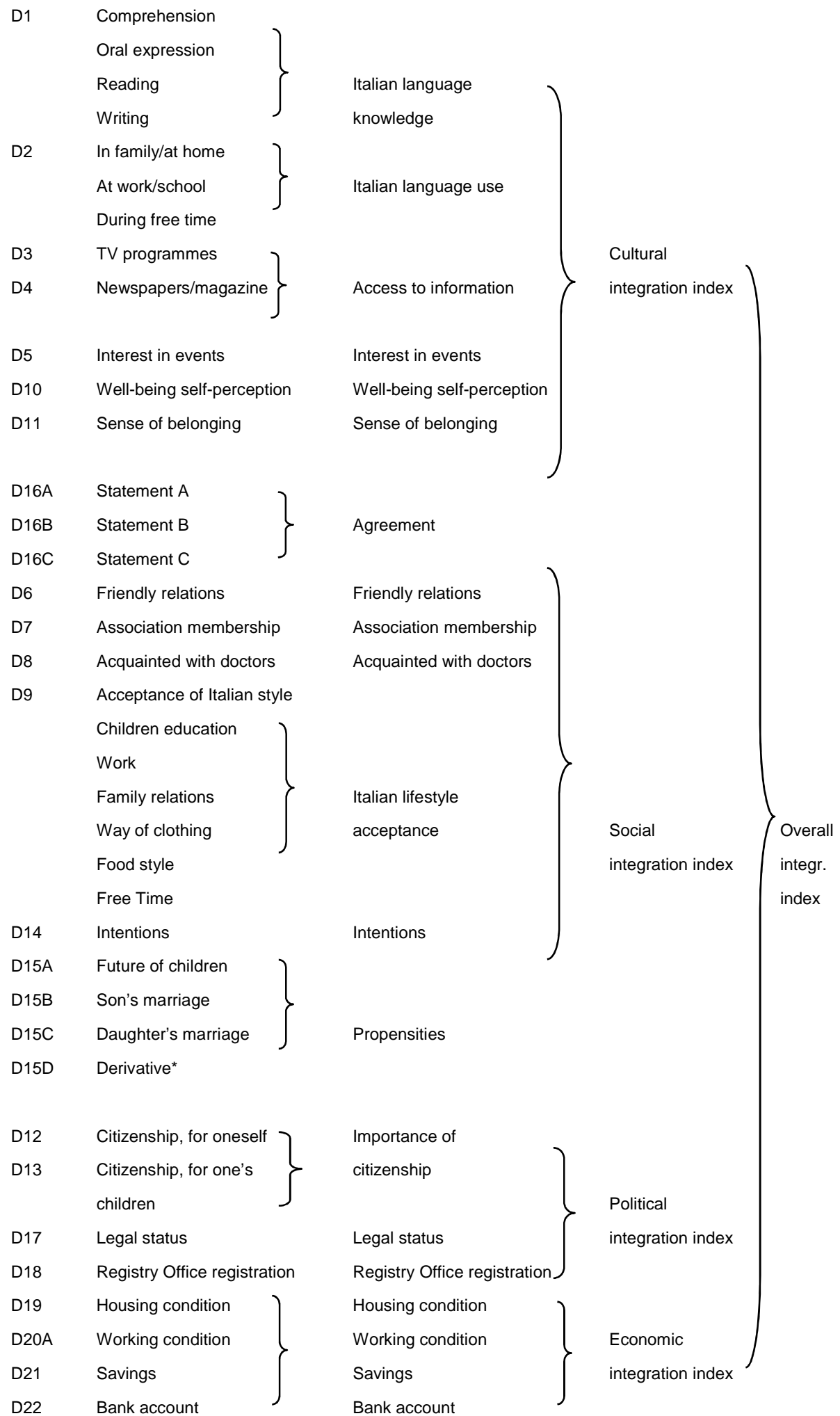

Source: Cesareo and Blangiardo (2009)

Notes:* Assuming as reference that an Italian well-integrated citizen does not support differences on grounds of gender, items 15.B and 15.C were used for drawing variable 15.D, propensity to equal opportunities (answer in agreement = integrated; answer in disagreement $=$ not integrated). 